\title{
A Review of Ethnoveterinary Knowledge, Biological Activities and Secondary Metabolites of Medicinal Woody Plants Used for Managing Animal Health in South Africa
}

\author{
Kelebogile Martha Selogatwe ${ }^{1,2}$, John Awungnjia Asong 2,3®D, Madeleen Struwig ${ }^{2}$, Rendani Victress Ndou 4 \\ and Adeyemi Oladapo Aremu $1,3, *$ (D) \\ 1 Food Security and Safety Niche Area, Faculty of Natural and Agricultural Sciences, North-West University, \\ Private Bag X2046, Mmabatho 2790, South Africa; kselogatwe@gmail.com \\ 2 Unit for Environmental Sciences and Management, Faculty of Natural and Agricultural Sciences, \\ North-West University, Private Bag X2046, Mmabatho 2790, South Africa; johnmilan058@gmail.com (J.A.A.); \\ 12516309@nwu.ac.za (M.S.) \\ 3 Indigenous Knowledge Systems Centre, Faculty of Natural and Agricultural Sciences, North-West University, \\ Private Bag X2046, Mmabatho 2790, South Africa \\ 4 Centre of Animal Health Studies, Faculty of Natural and Agricultural Sciences, North-West University, \\ Private Bag X2046, Mmabatho 2790, South Africa; rendani.ndou@nwu.ac.za \\ * Correspondence: Oladapo.Aremu@nwu.ac.za; Tel.: +27-18-389-2573
}

Citation: Selogatwe, K.M.; Asong, J.A.; Struwig, M.; Ndou, R.V.; Aremu, A.O. A Review of Ethnoveterinary Knowledge, Biological Activities and Secondary Metabolites of Medicinal Woody Plants Used for Managing Animal Health in South Africa. Vet. Sci. 2021, 8, 228. https://doi.org/ $10.3390 /$ vetsci 8100228

Academic Editors: Huisheng Xie, Jiahao Lin, Kai Fan and Jennifer Ketzis

Received: 5 September 2021 Accepted: 8 October 2021

Published: 12 October 2021

Publisher's Note: MDPI stays neutral with regard to jurisdictional claims in published maps and institutional affiliations.

Copyright: (C) 2021 by the authors. Licensee MDPI, Basel, Switzerland. This article is an open access article distributed under the terms and conditions of the Creative Commons Attribution (CC BY) license (https:/ / creativecommons.org/licenses/by/ $4.0 /)$.

\begin{abstract}
Globally, the use of ethnoveterinary medicine as remedies for animal health among different ethnic groups justify the need for a systematic exploration to enhance their potential. In addition, the increasing popularity and utilisation of woody plants remain common in traditional medicine, which may be attributed to their inherent benefits. The current review was aimed at analysing ethnoveterinary surveys, biological activities, and secondary metabolites/phytochemical profiles of the woody plants of South Africa. Eligible literature (period: 2000 to 2020) were retrieved from different databases such as Google Scholar, PubMed, Sabinet, and Science Direct. Based on the inclusion and exclusion criteria, 20 ethnoveterinary surveys were eligible and were subjected to further analysis. We identified 104 woody plant species from 44 plant families that are used in the treatment of different diseases in animals, particularly cattle (70\%) and goats $(20 \%)$. The most mentioned (with six citations) woody plants were Terminalia sericea Burch. ex DC and Ziziphus mucronata Willd., which were followed by plants with five (Cussonia spicata Thunb., Pterocarpus angolensis DC and Vachellia karroo (Hayne) Banfi \& Galasso) or four (Acokanthera oppositifolia (Lam.) Codd, Cassia abbreviata Oliv., and Strychnos henningsii Gilg) individual mentions. The most dominant families were Fabaceae (19\%), Apocynaceae (5.8\%), Rubiaceae (5.8\%), Anacardiaceae (4.8\%), Combretaceae (4.8\%), Euphorbiaceae $(4.8 \%)$, Malvaceae $(4.8 \%)$, Rhamnaceae (4.8\%), and Celastraceae (3.8\%). Bark (33\%), leaves (29\%), and roots $(19 \%)$ were the plant parts dominantly used to prepare remedies for ethnoveterinary medicine. An estimated $20 \%$ of woody plants have been screened for antimicrobial, anthelmintic, antioxidant, and cytotoxicity effects. Phytochemical profiles established a rich pool of valuable secondary metabolites (phenolic, flavonoids and condensed tannins) that may be responsible for the exerted biological activities. Overall, the significant portion of woody plants lacking empirical evidence on their biological effects indicates a major knowledge gap that requires more research efforts.
\end{abstract}

Keywords: antibacterial; antioxidant; ethnoveterinary; Fabaceae; livestock diseases; retained placenta

\section{Introduction}

Globally, many animals, especially cattle, goats, and horses, play diverse role in human life, ranging from being a source of food, income and cultural wealth, touristic attraction, and job creation [1-6]. The rearing of animals is well-embedded in the culture of many ethnic groups, which justifies the popularity of indigenous knowledge and practice for managing the health and well-being of animals [5,7-11]. Relative to ethnobiology/ethnobotany, 
this is currently considered as a distinct field known as ethnoveterinary medicine, a word coined by the American anthropologist Constance McCorkle [12]. It is defined as "the systematic study and application of folk knowledge and beliefs, practices that relate to any aspects of animal health" [13]. Based on increasing evidence [6,14], the field has the capacity to develop into a huge industry in the future. Although animal species and plant species are utilised in ethnoveterinary medicine, the latter is often more popular among many ethnic groups globally [5,11]. Particularly in South Africa, the importance of plants for the management of animal health and well-being cannot be over-emphasized [15].

South Africa has a huge flora diversity and is recognised as a mega-diverse country with three global biodiversity hotspots [16]. The country has an estimated 24,000 species distributed among 368 families, which accounts for approximately $10 \%$ of the world's flora [17]. As a result, South Africans have tapped into the healing powers of these floras since time immemorial, and this knowledge has been retained and has continuously evolved through generations [18]. In some cases, the choice of plants is based on an indigenous experimental process, cultural beliefs, and the biodiversity in a particular area [19-22].

In Africa, woody plants (trees and shrubs) are an important defining feature of the landscapes $[20,23]$. They are widely recognised for their diverse uses by humans since ancient times $[20,24,25]$. Particularly in traditional medicine, woody plant species have essential roles that are easily exemplified, as they represent about $65 \%$ of the top 51 most important African medicinal plants [26]. Recent studies from different African countries including South African have reiterated the vital role of woody plants in human and animal healthcare as well as the need for more concerted efforts for their conservation [25,27-30]. An important attribute of woody plants is the wide range of their organs (leaves, bark, roots, fruits, and flowers) that is available for use as remedies in folk medicine [25,27]. Relative to herbaceous plants with short life cycles, woody plants are often dominant in ecosystems, thereby making them apparent to foraging animals and for utilisation by humans [20,21]. In the current review, we aim to provide an appraisal on the existing ethnoveterinary knowledge, biological activities, and secondary metabolites/phytochemical profiles of woody plants used for managing animal health in South Africa. The review is expected to identify existing research gap(s) in an attempt to explore the potential of woody plants as an alternative remedy for managing animal health.

\section{Materials and Methods}

The literature search strategy was facilitated using keywords such as woody plants, ethnoveterinary medicine, livestock, and animal health. In addition, phytochemical, antioxidant, phenolic, and antibacterial effect were examples of terms used to generate data for the biological activity and phytochemical aspects of this review. These keywords were used singly and in combination to identify suitable literature from several databases, namely Google Scholar, Pubmed, Science Direct, and Sabinet. We focused on peer-reviewed papers published from 2000 to 2020 on South African woody plants.

Screening of the research outputs from the databases was conducted in two stages. Firstly, the title and abstract of the papers were screened against the inclusion criteria. A publication needed to provide the Latin name for the woody plant to be eligible for inclusion. Articles reporting on ethnoveterinary uses, biological activities, and phytochemical analyses of the woody plants fulfilled the inclusion criteria (e.g., specified time duration, woody species, and South African studies). Review papers and studies not involving South African medicinal woody plants were excluded. Based on the selection criteria, 20 papers were selected and were analysed in order to generate an inventory of woody plants (Table 1). Subsequently, analyses on plant families, mode of preparation, plant parts used to treat animals/livestock diseases, biological activities, and phytochemicals were conducted. Based on the significance of scientific names [31,32], the botanical names were validated via multi-databases, such as PlantZAfrica (http://pza.sanbi.org/ (accessed on 29 September 2021)), The Plant List (http:/ /www.theplantlist.org/ (accessed 
on 29 September 2021)), and The World Flora Online (http:/ /www.worldfloraonline.org/ (accessed on 29 September 2021)).

Table 1. An overview of ethnoveterinary surveys with evidence on the use of woody plants in South Africa from 2000-2020.

\begin{tabular}{|c|c|c|c|c|c|c|c|}
\hline \multirow{2}{*}{ Reference } & \multirow{2}{*}{ Province } & \multicolumn{2}{|c|}{ Documented Plants } & \multicolumn{2}{|c|}{$\begin{array}{l}\text { Documented } \\
\text { Woody Plants }\end{array}$} & \multirow{2}{*}{$\begin{array}{l}\text { Method of } \\
\text { Survey/Interview }\end{array}$} & \multirow{2}{*}{$\begin{array}{l}\text { Number of } \\
\text { Participants }\end{array}$} \\
\hline & & $\begin{array}{l}\text { Number } \\
\text { of Plants }\end{array}$ & $\begin{array}{l}\text { Number of } \\
\text { Families }\end{array}$ & $\begin{array}{l}\text { Number } \\
\text { of Plants }\end{array}$ & $\begin{array}{l}\text { Number of } \\
\text { Families }\end{array}$ & & \\
\hline Chitura et al., [33] & Limpopo & 11 & 10 & 7 & 4 & $\begin{array}{l}\text { Structured } \\
\text { questionnaire }\end{array}$ & 180 \\
\hline Dold and Cocks [34] & Eastern Cape & 53 & 42 & 21 & 18 & $\begin{array}{l}\text { Questionnaire and } \\
\text { field interview }\end{array}$ & Not specified \\
\hline Kambizi [35] & Eastern Cape & 22 & 19 & 8 & 7 & $\begin{array}{l}\text { Semi-structured } \\
\text { interview }\end{array}$ & Not specified \\
\hline Khunoana et al., [36] & Mpumalanga & 11 & 9 & 6 & 4 & $\begin{array}{l}\text { Semi-structured } \\
\text { interview }\end{array}$ & 50 \\
\hline $\begin{array}{l}\text { Luseba and } \\
\text { Tshisikhawe [37] }\end{array}$ & Limpopo & 34 & 22 & 21 & 13 & $\begin{array}{l}\text { Focus group } \\
\text { discussion }\end{array}$ & 37 \\
\hline $\begin{array}{l}\text { Luseba and Van der } \\
\text { Merwe [38] }\end{array}$ & Limpopo & 19 & 12 & 9 & 6 & $\begin{array}{l}\text { Individual and } \\
\text { group interview }\end{array}$ & Not specified \\
\hline Magwede et al., [39] & Limpopo & 27 & 14 & 15 & 9 & $\begin{array}{l}\text { Open-ended } \\
\text { questions and } \\
\text { semi-structured } \\
\text { questionnaire }\end{array}$ & 42 \\
\hline Mahlo [40] & Limpopo & 5 & 4 & 5 & 4 & Not specified & Not specified \\
\hline Maphosa and Masika [41] & Eastern Cape & 28 & 20 & 12 & 9 & $\begin{array}{l}\text { Structured } \\
\text { questionnaire and } \\
\text { general } \\
\text { conversation }\end{array}$ & 30 \\
\hline Mkwanazi et al., [42] & KwaZulu-Natal & 5 & 4 & 1 & 1 & $\begin{array}{l}\text { Structured } \\
\text { questionnaire }\end{array}$ & Not specified \\
\hline Moichwanetse et al., [43] & North West & 25 & 18 & 8 & 5 & $\begin{array}{l}\text { Face-to-face, } \\
\text { semi-structured } \\
\text { interview }\end{array}$ & 15 \\
\hline Moyo and Masika [44] & Eastern Cape & 2 & 2 & 1 & 1 & $\begin{array}{l}\text { Structured } \\
\text { questionnaire }\end{array}$ & 59 \\
\hline Mthi et al., [45] & Eastern Cape & 6 & 6 & 4 & 3 & $\begin{array}{l}\text { Semi-structured } \\
\text { questionnaire, } \\
\text { observations and } \\
\text { guided field trip }\end{array}$ & 48 \\
\hline Mwale and Masika [46] & Eastern Cape & 9 & 7 & 1 & 1 & $\begin{array}{l}\text { Structured } \\
\text { questionnaire }\end{array}$ & 54 \\
\hline Ndou [47] & North West & 31 & 17 & 8 & 7 & $\begin{array}{l}\text { Semi structured } \\
\text { face-to-face } \\
\text { interview }\end{array}$ & 21 \\
\hline $\begin{array}{l}\text { Ramovha and } \\
\text { Van Wyk [48] }\end{array}$ & Limpopo & 20 & 10 & 14 & 8 & $\begin{array}{l}\text { Semi-structured } \\
\text { interview }\end{array}$ & Not specified \\
\hline Rwodzi [49] & Eastern Cape & 10 & 8 & 2 & 2 & Questionnaire & 60 \\
\hline Sanhokwe et al., [50] & Eastern Cape & 9 & 8 & 3 & 3 & $\begin{array}{l}\text { Structured } \\
\text { questionnaire }\end{array}$ & 53 \\
\hline Soyelu and Masika [51] & Eastern Cape & 13 & 11 & 7 & 6 & $\begin{array}{l}\text { Structured } \\
\text { questionnaire }\end{array}$ & 53 \\
\hline Van der Merwe et al., [52] & North West & 45 & 24 & 19 & 12 & Detailed interview & 28 \\
\hline
\end{tabular}




\section{Results and Discussion}

\subsection{Overview of Eligible Literature and Ethnoveterinary Studies}

The eligible studies were conducted in five of the nine provinces in South Africa. These included the Eastern Cape (45\%), Limpopo (30\%), North West (15\%) Mpumalanga $(5 \%)$, and KwaZulu-Natal (5\%) provinces (Table 1). The majority of these aforementioned provinces are regarded as predominantly rural-based, which may explain the continuous dependence on woody plants for veterinary needs. In a recent review of the ethnoveterinary plants of South Africa, McGaw et al., [15] indicated a similar distribution pattern relating to the use of medicinal plants as remedies for animals/livestock in South Africa. In Pakistan, a rich ethnoveterinary knowledge was recorded in communities residing in remote areas with limited access to conventional veterinary services, which often forced the inhabitants to rely on the natural resources within their immediate environment to meet the health needs of their livestock [14].

The data collection methods included the use of questionnaires, interviews, field observations, and Rapid Rural Appraisal (Table 1). Data on ethnoveterinary medicine was collected from diverse participants such as farmers, cattle headers, indigenous knowledge holders, and traditional healers. In terms of number, the number of participants ranged from 15 [43] to 180 [33] while about $30 \%$ of the studies had no indication of the sample size involved in the ethnobotanical survey. Given that the primary focus of these surveys was not on woody plants, varying portions (11-100\%) of woody species were identified in the recorded plants (Table 1). In the survey in the Eastern Cape by Dold and Cocks [34], approximately $40 \%$ of the 53 recorded plants with ethnoveterinary value were woody plant species. A similar trend was evident in other ethnoveterinary surveys in the Eastern Cape $[35,41,51]$ and Limpopo [48] provinces. In North West province, the portion of woody plants ranged from $26 \%$ [47,52] to $32 \%$ [43]. In an attempt to understand the basis for the selection and utilisation of plants by local communities, several theories and hypotheses exist [53]. In the current situation, the ecological apparency hypothesis likely accounts for the use of woody plants for ethnoveterinary medicine among local communities. Even though South Africa is recognized as being rich in biodiversity and diverse vegetation-types, it remains highly susceptible due to rapid development, habitat loss, and overexploitation [16]. Increasing evidence supported the dynamic nature of the existing vegetation in South Africa, which is associated with the effects of climate change [54]. On this basis, it is often difficult to predict the pattern for the use of woody plants in ethnoveterinary medicine.

\subsection{Inventory of Woody Plants with Ethnoveterinary Uses}

The high reliance on plants for managing livestock/animals among local communities, especially in developing countries, remains a common trend [14,55]. This popularity has often been attributed to the limited access to convention veterinary drugs and the existence of vast indigenous knowledge for managing livestock in rural communities $[47,56,57]$. Several studies have revealed that traditional medicines are mostly used because they are regarded as effective and readily available as well as accessible. As often indicated by participants in ethnoveterinary surveys, dependence on traditional medicines is common because western veterinary facilities are inaccessible and are too costly for resource-poor livestock farmers [34,37,45].

Based on the 20 eligible studies from the literature, we generated 104 woody plants with diverse ethnoveterinary uses in South Africa (Table 2). Terminalia sericea Burch. Ex DC and Ziziphus mucronata Willd were the most common plants, with six mentions. Furthermore, Cussonia spicata Thunb., Pterocarpus angolensis DC., and Vachellia karroo (Hayne) Banfi \& Galasso (five citations) and Cassia abbreviata Oliv. and Strychnos henningsii Gilg (four citations) were popular within the 20 analysed studies from the literature. On the other hand, the majority ( $86 \%$, i.e., 89 plants) of the 104 woody plants had limited (1-2) mentions. 


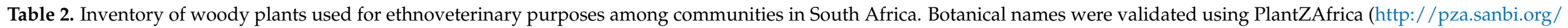

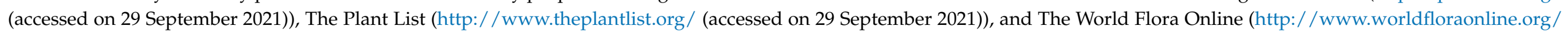
(accessed on 29 September 2021)). Syn = synonym; ns = not specified.

\begin{tabular}{|c|c|c|c|c|c|c|c|}
\hline Plant Species & Family & Common Name & $\begin{array}{l}\text { Method of Preparation } \\
\text { and Administration }\end{array}$ & $\begin{array}{l}\text { Plant Part } \\
\text { Used }\end{array}$ & $\begin{array}{l}\text { Animal } \\
\text { Treated }\end{array}$ & $\begin{array}{l}\text { Disease/Health } \\
\text { Condition }\end{array}$ & Reference \\
\hline $\begin{array}{l}\text { Acokanthera oppositifolia } \\
\text { (Lam.) Codd }\end{array}$ & Apocynaceae & Bushman's Poison & $\begin{array}{l}\text { Leaves are boiled for } 10 \mathrm{~min} \text {, strained, } \\
\text { and left to stand overnight }\end{array}$ & Leaves & $\begin{array}{l}\text { Sheep, } \\
\text { goats }\end{array}$ & Heartwater & Dold and Cocks [34] \\
\hline $\begin{array}{l}\text { Acokanthera oppositifolia } \\
\text { (Lam.) Codd }\end{array}$ & Apocynaceae & Bushman's Poison & Decoction & Leaves & Goats & $\begin{array}{l}\text { Gastrointestinal } \\
\text { parasites }\end{array}$ & Maphosa and Masika [41] \\
\hline $\begin{array}{l}\text { Acokanthera oppositifolia } \\
\text { (Lam.) Codd }\end{array}$ & Apocynaceae & Bushman's Poison & $\begin{array}{l}\text { Leaves crushed with water and } \\
\text { administered orally }\end{array}$ & Leaves & Cattle & Paratyphoid (Goso) & Mthi et al., [45] \\
\hline $\begin{array}{l}\text { Afrocarpus falcatus } \\
\text { (Thunb.) C.N.Page }\end{array}$ & Podocarpaceae & $\begin{array}{l}\text { Outeniqua } \\
\text { yellowwood }\end{array}$ & Decoction & Leaves & Dogs & Distemper & Dold and Cocks [34] \\
\hline Albizia sp. & Fabaceae & Xisitana & $\begin{array}{l}\text { Root skin is infused in water and is } \\
\text { left overnight }\end{array}$ & Roots & Cattle & Swollen stomach & Khunoana et al., [36] \\
\hline Azima tetracantha Lam. & Salvadoraceae & Beehanger & $\begin{array}{l}\text { Dried and ground root is bottled in } \\
\text { cold water }\end{array}$ & Root & Cattle & Dystocia & Dold and Cocks [34] \\
\hline $\begin{array}{l}\text { Balanites maughamii } \\
\text { Sprague }\end{array}$ & Zygophyllaceae & Torchwood & Decoction & Leaves & Cattle & Diarrhoea & Mahlo [40] \\
\hline $\begin{array}{l}\text { Balanites maughamii } \\
\text { Sprague }\end{array}$ & Zygophyllaceae & Torchwood & $\begin{array}{l}\text { Ground leaves are mixed with } \\
\text { cold water }\end{array}$ & Leaves & Cattle & Diarrhoea & Van der Merwe et al., [52] \\
\hline $\begin{array}{l}\text { Bauhinia thonningii } \\
\text { Schum. (Syn: } \\
\text { Piliostigma thonningii } \\
\text { (Schumach.) } \\
\text { Milne-Redh.) }\end{array}$ & Fabaceae & Camel's foot & Decoction & Leaves & Cattle & Diarrhoea & Mahlo [40] \\
\hline $\begin{array}{l}\text { Bolusanthus speciosus } \\
\text { (Bolus) Harms }\end{array}$ & Fabaceae & Tree wisteria & Pounded roots are immersed in water & Roots & Cattle & Retained placenta & $\begin{array}{l}\text { Luseba and } \\
\text { Tshisikhawe [37] }\end{array}$ \\
\hline
\end{tabular}


Table 2. Cont.

\begin{tabular}{|c|c|c|c|c|c|c|c|}
\hline Plant Species & Family & Common Name & $\begin{array}{l}\text { Method of Preparation } \\
\text { and Administration }\end{array}$ & $\begin{array}{l}\text { Plant Part } \\
\text { Used }\end{array}$ & $\begin{array}{l}\text { Animal } \\
\text { Treated }\end{array}$ & $\begin{array}{l}\text { Disease/Health } \\
\text { Condition }\end{array}$ & Reference \\
\hline $\begin{array}{l}\text { Brachylaena ilicifolia } \\
\text { (Lam.) E. Phillips } \\
\text { \& Schweick. }\end{array}$ & Asteraceae & Bitterblaar & $\begin{array}{l}\text { Leaves are mixed with leaves of Leucas } \\
\text { capensis (Benth.) Engl. and sap of Aloe } \\
\text { ferox Mill and boiled }\end{array}$ & Leaves & Lambs & Diarrhoea & Dold and Cocks [34] \\
\hline $\begin{array}{l}\text { Breonadia salicina (Vahl) } \\
\text { Hepper \& J.R.I.Wood }\end{array}$ & Rubiaceae & Transvaal teak & Maceration & Bark & Cattle & $\begin{array}{l}\text { General intestinal } \\
\text { diseases and } \\
\text { retained placenta }\end{array}$ & Mahlo [40] \\
\hline $\begin{array}{l}\text { Cadaba aphylla } \\
\text { (Thunb.) Wild }\end{array}$ & Capparaceae & $\begin{array}{l}\text { leafless cadaba, } \\
\text { leafless wormbush, } \\
\text { black storm }\end{array}$ & $\begin{array}{l}\text { Root decoction: Combined with roots of } \\
\text { Ziziphus zeyheriana, Senna italica, and } \\
\text { Dicoma galpinii }\end{array}$ & Root & ns & $\begin{array}{l}\text { Blood cleansing and } \\
\text { pains (sores, } \\
\text { fractures) }\end{array}$ & Ndou [47] \\
\hline $\begin{array}{l}\text { Calpurnia aurea } \\
\text { (Aiton) Benth. }\end{array}$ & Fabaceae & Common calpurnia & Infusion & Leaves & Cattle & $\begin{array}{l}\text { Maggot-infested } \\
\text { wounds }\end{array}$ & Soyelu and Masika [51] \\
\hline Capparis sepiaria $\mathrm{L}$. & Capparaceae & Cape Capers & Infusion & Roots & Goats & $\begin{array}{l}\text { Gastro-intestinal } \\
\text { parasites }\end{array}$ & Maphosa and Masika [41] \\
\hline Cassia abbreviata Oliv. & Fabaceae & Sjambok pod & Bark infusion & Bark & Cattle & Retained placenta & Chitura et al., [33] \\
\hline Cassia abbreviata Oliv. & Fabaceae & Sjambok pod & $\begin{array}{l}\text { Ground bark is soaked in water } \\
\text { overnight or boiled }\end{array}$ & Bark & ns & Worm infestation & $\begin{array}{l}\text { Luseba and } \\
\text { Van der Merwe [38] }\end{array}$ \\
\hline Cassia abbreviata Oliv. & Fabaceae & Sjambok pod & Ground bark is mixed with water & Bark & Cattle & Wounds & Magwede et al., [39] \\
\hline Cassia abbreviata Oliv. & Fabaceae & Sjambok pod & Bark infusion or decoction & $\begin{array}{l}\text { Bark, root } \\
\text { bark }\end{array}$ & Cattle & Redwater & $\begin{array}{l}\text { Ramovha and } \\
\text { Van Wyk [48] }\end{array}$ \\
\hline $\begin{array}{l}\text { Cassine aethiopica Thunb. } \\
\text { (Syn: } \\
\text { Mystroxylon aethiopicum } \\
\text { (Thunb.) Loes.) }\end{array}$ & Celastraceae & Kooboo-berry & Bark is grated and boiled for $20 \mathrm{~min}$ & Bark & Cattle & Heartwater & Dold and Cocks [34] \\
\hline Centella asiatica (L.) Urb. & Apiaceae & Varkoortjie & Decoction & Bark & Goats & Helminths & Sanhokwe et al., [50] \\
\hline
\end{tabular}


Table 2. Cont

\begin{tabular}{|c|c|c|c|c|c|c|c|}
\hline Plant Species & Family & Common Name & $\begin{array}{l}\text { Method of Preparation } \\
\text { and Administration }\end{array}$ & $\begin{array}{l}\text { Plant Part } \\
\text { Used }\end{array}$ & $\begin{array}{l}\text { Animal } \\
\text { Treated }\end{array}$ & $\begin{array}{l}\text { Disease/Health } \\
\text { Condition }\end{array}$ & Reference \\
\hline $\begin{array}{l}\text { Cephalanthus natalensis } \\
\text { Oliv. }\end{array}$ & Rubiaceae & Strawberry bush & Infusion & Leaves & Cattle & Eye problem & $\begin{array}{l}\text { Luseba and } \\
\text { Tshisikhawe [37] }\end{array}$ \\
\hline Cissampelos capensis L.f. & Menispermaceae & Davidjies & ns & Roots & ns & $\begin{array}{l}\text { Skin problems, } \\
\text { wounds }\end{array}$ & Kambizi [35] \\
\hline Clutia pulchella L. & Peraceae & Lightning bush & Decoction & Roots & Cattle & Gall & Khunoana et al., [36] \\
\hline $\begin{array}{l}\text { Coddia rudis (E.Mey. ex. } \\
\text { Harv.) Verdc. }\end{array}$ & Rubiaceae & Small bone apple & ns & Leaves & Leaves & $\begin{array}{l}\text { Skin problems } \\
\text { (eliminates ticks) }\end{array}$ & Kambizi [35] \\
\hline $\begin{array}{l}\text { Combretum collinum } \\
\text { Fresen }\end{array}$ & Combretaceae & $\begin{array}{l}\text { Bicoloured } \\
\text { bushwillow }\end{array}$ & ns & Bark & Cattle & Constipation & Chitura et al., [33] \\
\hline $\begin{array}{l}\text { Combretum microphyllum } \\
\text { Klotzsch. }\end{array}$ & Combretaceae & Flame creeper & Infusion or decoction & Roots & Cattle & Redwater & $\begin{array}{l}\text { Ramovha and } \\
\text { Van Wyk [48] }\end{array}$ \\
\hline $\begin{array}{l}\text { Combretum molle R.Br } \\
\text { ex G.Don }\end{array}$ & Combretaceae & Velvet bushwillow & Infusion & Leaves & Cattle & $\begin{array}{l}\text { Gut conditions- } \\
\text { diarrhoea. Worm } \\
\text { infestation. Breeding } \\
\text { problems, difficult } \\
\text { calving }\end{array}$ & $\begin{array}{l}\text { Luseba and } \\
\text { Tshisikhawe [37] }\end{array}$ \\
\hline $\begin{array}{l}\text { Combretum paniculatum } \\
\text { Vent. }\end{array}$ & Combretaceae & Burning bush & Decoction & Root bark & Cattle & For fertility problems & $\begin{array}{l}\text { Luseba and } \\
\text { Van der Merwe [38] }\end{array}$ \\
\hline $\begin{array}{l}\text { Croton gratissimus Burch. } \\
\text { (Syn: Croton gratissimus } \\
\text { Burch. var gratissimus) }\end{array}$ & Euphorbiaceae & $\begin{array}{l}\text { lavender croton, } \\
\text { lavender fever berry }\end{array}$ & $\begin{array}{l}\text { Dried leaves are crushed and mixed } \\
\text { with supplement feed }\end{array}$ & Leaves & ns & $\begin{array}{l}\text { Fertility } \\
\text { enhancement in } \\
\text { livestock }\end{array}$ & Ndou [47] \\
\hline $\begin{array}{l}\text { Croton gratissimus Burch. } \\
\text { (Syn: Croton gratissimus } \\
\text { Burch. var gratissimus) }\end{array}$ & Euphorbiaceae & Lavender fever berry & ns & Leaves & Cattle & Pneumonia & Van der Merwe et al., [52] \\
\hline $\begin{array}{l}\text { Curtisia dentata (Brum. f.) } \\
\text { C.A.Smith }\end{array}$ & Curtisiaceae & Assegai & $\begin{array}{l}\text { Bark, together with the bark of } \\
\text { Rapanea melanophloeos (L.) Mez, is boiled } \\
\text { for } 30 \mathrm{~min}\end{array}$ & Bark & Cattle & Heartwater & Dold and Cocks [34] \\
\hline
\end{tabular}


Table 2. Cont.

\begin{tabular}{|c|c|c|c|c|c|c|c|}
\hline Plant Species & Family & Common Name & $\begin{array}{l}\text { Method of Preparation } \\
\text { and Administration }\end{array}$ & $\begin{array}{l}\text { Plant Part } \\
\text { Used }\end{array}$ & $\begin{array}{l}\text { Animal } \\
\text { Treated }\end{array}$ & $\begin{array}{l}\text { Disease/Health } \\
\text { Condition }\end{array}$ & Reference \\
\hline Cussonia spicata Thunb. & Araliaceae & Cabbage-tree & $\begin{array}{l}\text { Mixed with leaves of Olea europaea L. } \\
\text { subsp. africana (Mill.) P.S.Green to } \\
\text { produce concoction or decoction }\end{array}$ & Leaves & Cattle & $\begin{array}{l}\text { Bloody urine after } \\
\text { calving } \\
\text { (endometritus } \\
\text { and/or vaginitis) }\end{array}$ & Dold and Cocks [34] \\
\hline Cussonia spicata Thunb. & Araliaceae & Cabbage-tree & ns & Bark & ns & Heartwater & Kambizi [35] \\
\hline Cussonia spicata Thunb. & Araliaceae & Cabbage-tree & Infusion & Bark & Goats & $\begin{array}{l}\text { Gastro-intestinal } \\
\text { parasites }\end{array}$ & Maphosa and Masika [41] \\
\hline Cussonia spicata Thunb. & Araliaceae & Cabbage-tree & $\begin{array}{l}\text { Ground bark is soaked overnight and } \\
\text { dose at } 300 \mathrm{~mL}\end{array}$ & Bark & Goats & Helmenthis & Sanhokwe et al., [50] \\
\hline Cussonia spicata Thunb. & Araliaceae & Cabbage-tree & ns & Bark & Cattle & $\begin{array}{l}\text { Treat retained } \\
\text { afterbirth. }\end{array}$ & Van der Merwe et al., [52] \\
\hline Dalbergia obovata E.Mey. & Fabaceae & Climbing flat bean & $\begin{array}{l}\text { Leaves and bark crushed and mixed } \\
\text { with water }\end{array}$ & $\begin{array}{l}\text { Leaves, } \\
\text { bark }\end{array}$ & Cattle & Paratyphoid (Goso) & Mthi et al., [45] \\
\hline $\begin{array}{l}\text { Dichrostachys cinerea (L.) } \\
\text { Wight \& Arn. }\end{array}$ & Fabaceae & Sicklebush & Dried fruit is made into powder & Fruit & $\begin{array}{l}\text { Sheep, } \\
\text { goats }\end{array}$ & Wounds & Chitura et al., [33] \\
\hline $\begin{array}{l}\text { Diospyros lycioides Desf. } \\
\text { (Syn: Diospyros lycioides } \\
\text { Desf. subsp. lyciodes) }\end{array}$ & Ebenaceae & $\begin{array}{l}\text { Bluebush, Karoo } \\
\text { blue bush }\end{array}$ & $\begin{array}{l}\text { Ground leaves are mixed with water } \\
\text { and apply on the affected area }\end{array}$ & Leaves & Cattle & Ticks & $\begin{array}{l}\text { Luseba and } \\
\text { Tshisikhawe [37] }\end{array}$ \\
\hline $\begin{array}{l}\text { Diospyros lycioides Desf. } \\
\text { (Syn: Diospyros lycioides } \\
\text { Desf. subsp. lyciodes) }\end{array}$ & Ebenaceae & $\begin{array}{l}\text { Bluebush, Karoo } \\
\text { blue bush }\end{array}$ & $\begin{array}{l}\text { Leaves are crushed and mixed } \\
\text { with water }\end{array}$ & Leaves & Cattle & Wounds & Magwede et al., [39] \\
\hline $\begin{array}{l}\text { Diospyros mespiliformis } \\
\text { Hochst. ex A.DC. }\end{array}$ & Ebeneceae & African ebony & $\begin{array}{l}\text { Ground bark is mixed with } \\
\text { hippopotamus fat; dosed and also } \\
\text { rubbed into vagina }\end{array}$ & Bark & ns & For milk production & $\begin{array}{l}\text { Luseba and } \\
\text { Van der Merwe [38] }\end{array}$ \\
\hline $\begin{array}{l}\text { Diospyros mespiliformis } \\
\text { Hochst. ex A.DC. }\end{array}$ & Ebeneceae & African ebony & $\begin{array}{l}\text { Ground roots are mixed with warm but } \\
\text { not boiling water to yield an infusion }\end{array}$ & Roots & Cattle & Redwater & $\begin{array}{l}\text { Ramovha and } \\
\text { Van Wyk [48] }\end{array}$ \\
\hline
\end{tabular}


Table 2. Cont

\begin{tabular}{|c|c|c|c|c|c|c|c|}
\hline Plant Species & Family & Common Name & $\begin{array}{l}\text { Method of Preparation } \\
\text { and Administration }\end{array}$ & $\begin{array}{l}\text { Plant Part } \\
\text { Used }\end{array}$ & $\begin{array}{l}\text { Animal } \\
\text { Treated }\end{array}$ & $\begin{array}{l}\text { Disease/Health } \\
\text { Condition }\end{array}$ & Reference \\
\hline $\begin{array}{l}\text { Dombeya rotundifolia } \\
\text { (Hochst.) Planch. }\end{array}$ & Malvaceae & Wild pear & $\begin{array}{l}\text { Ground leaves/flowers are mixed with } \\
\text { chicken feed }\end{array}$ & $\begin{array}{l}\text { Leaves, } \\
\text { flowers }\end{array}$ & Chicken & Newcastle disease & $\begin{array}{l}\text { Luseba and } \\
\text { Van der Merwe [38] }\end{array}$ \\
\hline $\begin{array}{l}\text { Dombeya rotundifolia } \\
\text { (Hochst.) Planch. }\end{array}$ & Malvaceae & Wild pear & Decoction & Leaves & Cattle & Diarrhoea & Mahlo [40] \\
\hline $\begin{array}{l}\text { Ehretia rigida (Thunb.) } \\
\text { Druce }\end{array}$ & Boraginaceae & Puzzle bush & Decoction & Roots & Cattle & Eating problems & $\begin{array}{l}\text { Luseba and } \\
\text { Tshisikhawe [37] }\end{array}$ \\
\hline $\begin{array}{l}\text { Elaeodendron transvaalense } \\
\text { (Burtt Davy) R.H.Archer }\end{array}$ & Celastraceae & Bushveld saffron & Ground fruits are mixed with water & Fruit & Cattle & Worms & $\begin{array}{l}\text { Luseba and } \\
\text { Tshisikhawe [37] }\end{array}$ \\
\hline $\begin{array}{l}\text { Elaeodendron transvaalense } \\
\text { (Burtt Davy) R.H.Archer }\end{array}$ & Celastraceae & Spike-Thorn & ns & Bark & Cattle & Diarrhoea & Van der Merwe et al., [52] \\
\hline $\begin{array}{l}\text { Elephantorrhiza burkei } \\
\text { Benth. }\end{array}$ & Fabaceae & Elephant-root & $\begin{array}{l}\text { Ground bulb (or bark) is mixed } \\
\text { with water }\end{array}$ & $\begin{array}{l}\text { Bark, } \\
\text { roots }\end{array}$ & Cattle & Diarrhoea & $\begin{array}{l}\text { Luseba and } \\
\text { Tshisikhawe [37] }\end{array}$ \\
\hline Erythrina caffra Thunb. & Fabaceae & Coast coral tree & ns & Bark & ns & Heartwater & Kambizi [35] \\
\hline $\begin{array}{l}\text { Erythrina lysistemon } \\
\text { Hutch. }\end{array}$ & Fabaceae & Common coral tree & $\begin{array}{l}\text { Fresh bark is crushed into pulp and } \\
\text { juice is applied }\end{array}$ & Bark & Cattle & Wounds & Magwede et al., [39] \\
\hline Euphorbia cupularis Boiss. & Euphorbiaceae & Crying tree & $\begin{array}{l}\text { Milky latex is applied on third eyelid } \\
\text { and on the skin of the limping leg }\end{array}$ & $\begin{array}{l}\text { Milky } \\
\text { latex }\end{array}$ & ns & $\begin{array}{l}\text { Eye infection and } \\
\text { blackquarter }\end{array}$ & $\begin{array}{l}\text { Luseba and } \\
\text { Van der Merwe [38] }\end{array}$ \\
\hline $\begin{array}{l}\text { Euphorbia umbellata (Pax) } \\
\text { Bruyns }\end{array}$ & Euphorbiaceae & African milk bush & $\begin{array}{l}\text { Milky sap applied directly on the area } \\
\text { between the eye and ear }\end{array}$ & Stem & Cattle & Eye problem & Khunoana et al., [36] \\
\hline Ficus sp. & Moraceae & ns & ns & Bark & ns & Wounds & Kambizi [35] \\
\hline
\end{tabular}


Table 2. Cont

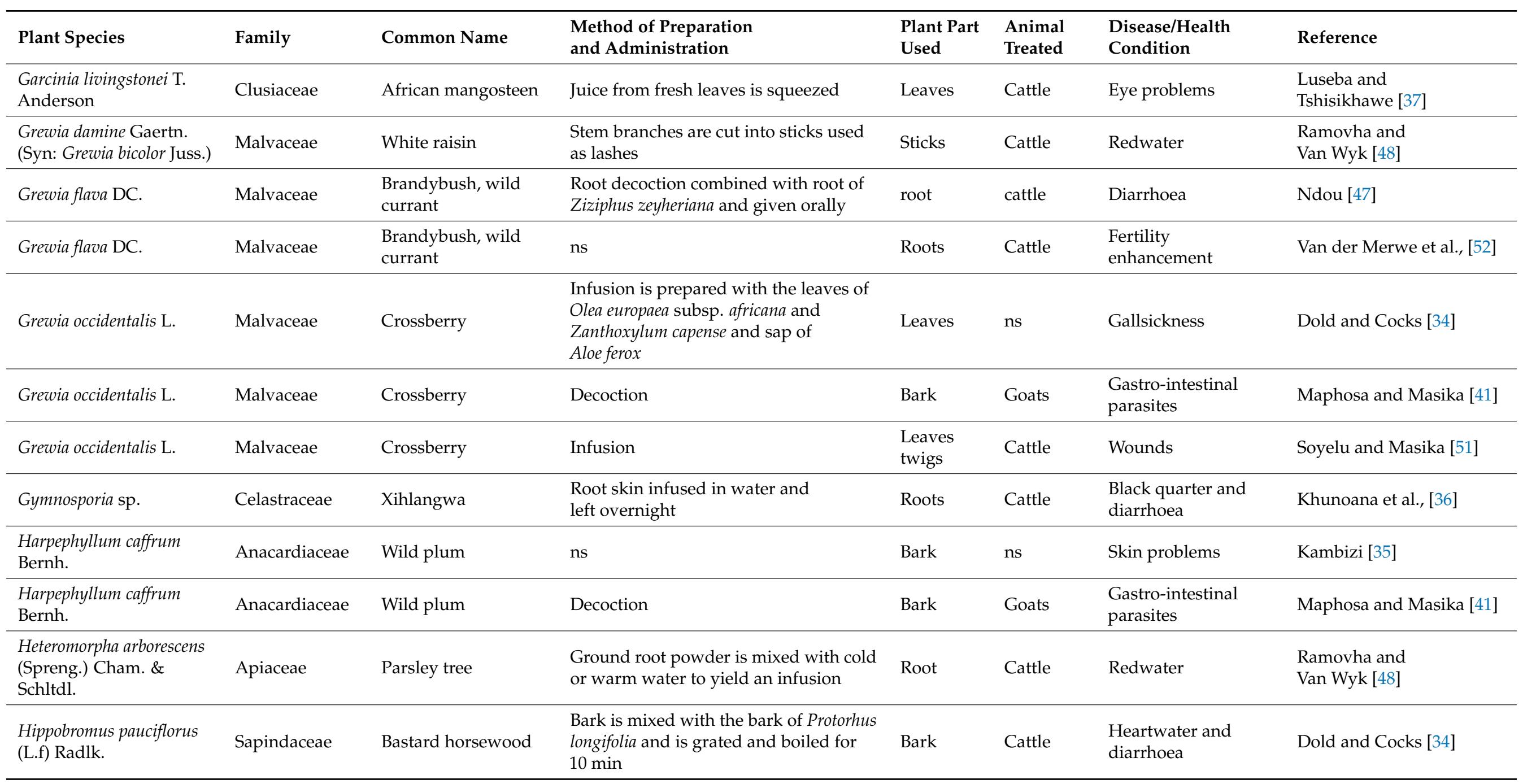


Table 2. Cont.

\begin{tabular}{|c|c|c|c|c|c|c|c|}
\hline Plant Species & Family & Common Name & $\begin{array}{l}\text { Method of Preparation } \\
\text { and Administration }\end{array}$ & $\begin{array}{l}\text { Plant Part } \\
\text { Used }\end{array}$ & $\begin{array}{l}\text { Animal } \\
\text { Treated }\end{array}$ & $\begin{array}{l}\text { Disease/Health } \\
\text { Condition }\end{array}$ & Reference \\
\hline $\begin{array}{l}\text { Hippobromus pauciflorus } \\
\text { (L.f) Radlk. }\end{array}$ & Sapindaceae & Bastard horsewood & Infusion & Leaves & Cattle & Wounds & Soyelu and Masika [51] \\
\hline $\begin{array}{l}\text { Holarrhena pubescens Wall. } \\
\text { ex G.Don }\end{array}$ & Apocynaceae & Conessi & $\begin{array}{l}\text { Crushed roots are mixed with hot water } \\
\text { to yield an infusion or are cooked to } \\
\text { produce a decoction }\end{array}$ & Root & Cattle & Redwater & $\begin{array}{l}\text { Ramovha and } \\
\text { Van Wyk [48] }\end{array}$ \\
\hline $\begin{array}{l}\text { Hyperacanthus amoenus } \\
\text { (Sims) Bridson }\end{array}$ & Rubiaceae & Thorny gardenia & Maceration & Bark & Cattle & $\begin{array}{l}\text { Relieving pain, loss } \\
\text { of appetite, and } \\
\text { general ailments }\end{array}$ & Mahlo [40] \\
\hline Jatropha curcas L. & Euphorbiaceae & Physic nut & $\begin{array}{l}\text { Crushed (1-2) seeds are mixed with } \\
\text { water for drenching }\end{array}$ & Seeds & $\begin{array}{l}\text { Cattle, } \\
\text { goats }\end{array}$ & Constipation & $\begin{array}{l}\text { Luseba and } \\
\text { Van der Merwe [38] }\end{array}$ \\
\hline Jatropha curcas L. & Euphorbiaceae & Physic nut & $\begin{array}{l}\text { Sliced root is cooked to produce a } \\
\text { decoction }\end{array}$ & $\begin{array}{l}\text { Root, } \\
\text { tuber }\end{array}$ & Cattle & Redwater & $\begin{array}{l}\text { Ramovha and } \\
\text { Van Wyk [48] }\end{array}$ \\
\hline Maerua angolensis DC. & Capparaceae & Bead-bean & $\begin{array}{l}\text { Ground leaves are mixed with water. } \\
\text { Fresh leaves are squeezed to } \\
\text { extract juice }\end{array}$ & Leaves & Cattle & $\begin{array}{l}\text { Eating disorder, } \\
\text { drought tonic, eye } \\
\text { problems, wounds }\end{array}$ & $\begin{array}{l}\text { Luseba and } \\
\text { Tshisikhawe [37] }\end{array}$ \\
\hline $\begin{array}{l}\text { Maytenus peduncularis } \\
\text { (Sond.) Loes. }\end{array}$ & Celastraceae & Blackwood & ns & Leaves & Goats & Ticks & Mkwanazi et al., [42] \\
\hline $\begin{array}{l}\text { Millettia grandis (E.Mey) } \\
\text { Skeels }\end{array}$ & Fabaceae & Umzimbeet & Soak the leaves in cold water & Leaves & Chicken & Internal parasites & Mwale and Masika [46] \\
\hline $\begin{array}{l}\text { Noltea africana (L.) } \\
\text { Rchb. f. }\end{array}$ & Rhamnaceae & Soap bush & Ground into powder & Roots & Goats & $\begin{array}{l}\text { Womb cleansing; } \\
\text { fertility }\end{array}$ & Rwodzi [49] \\
\hline Ochna holstii Engl. & Ochnaceae & $\begin{array}{l}\text { Common forest } \\
\text { ochna }\end{array}$ & $\begin{array}{l}\text { Leaves and branches boiled for } 2 \mathrm{~h} \text {, } \\
1 \text { litre is given once daily for } 3 \text { days }\end{array}$ & Leaves & $\begin{array}{l}\text { Goats, } \\
\text { sheep, } \\
\text { cattle }\end{array}$ & Wounds & $\begin{array}{l}\text { Luseba and } \\
\text { Tshisikhawe [37] }\end{array}$ \\
\hline Ochna holstii Engl. & Ochnaceae & $\begin{array}{l}\text { Common forest } \\
\text { ochna }\end{array}$ & Leaves are ground and boiled & $\begin{array}{l}\text { Leaves, } \\
\text { twigs, } \\
\text { bark }\end{array}$ & Cattle & Wounds & Magwede et al., [39] \\
\hline $\begin{array}{l}\text { Ocotea bullata (Burch.) } \\
\text { E. Meyer in Drege }\end{array}$ & Lauraceae & Stinkwood & Decoction & Bark & Goats & $\begin{array}{l}\text { Gastrointestinal } \\
\text { parasites }\end{array}$ & Maphosa and Masika [41] \\
\hline
\end{tabular}


Table 2. Cont

\begin{tabular}{|c|c|c|c|c|c|c|c|}
\hline Plant Species & Family & Common Name & $\begin{array}{l}\text { Method of Preparation } \\
\text { and Administration }\end{array}$ & $\begin{array}{l}\text { Plant Part } \\
\text { Used }\end{array}$ & $\begin{array}{l}\text { Animal } \\
\text { Treated }\end{array}$ & $\begin{array}{l}\text { Disease/Health } \\
\text { Condition }\end{array}$ & Reference \\
\hline $\begin{array}{l}\text { Olea europaea subsp. } \\
\text { cuspidata (Wall. \& G.Don) } \\
\text { Cif. (Syn: Olea europaea L. } \\
\text { subsp. africana (Mill.) } \\
\text { P.S.Green) }\end{array}$ & Oleaceae & Wild olive & $\begin{array}{l}\text { Bark infusion. Leaves together with } \\
\text { Cussonia spicata root. Mixture of } \\
\text { Zanthoxylum capense leaves, Grewia } \\
\text { occidentalis leaves, and Aloe ferox sap }\end{array}$ & $\begin{array}{l}\text { Bark, } \\
\text { leaves }\end{array}$ & $\begin{array}{l}\text { Goats, } \\
\text { cattle }\end{array}$ & $\begin{array}{l}\text { Diarrhoea in goats. } \\
\text { Bloody urine after } \\
\text { calving (endomitritis } \\
\text { and vaginitis in } \\
\text { cattle). Treating } \\
\text { gallsickness in cattle }\end{array}$ & Dold and Cocks [34] \\
\hline $\begin{array}{l}\text { Olea europaea subsp. } \\
\text { cuspidata (Wall. \& G.Don) } \\
\text { Cif. (Syn: Olea europaea L. } \\
\text { subsp. africana (Mill.) } \\
\text { P.S.Green) }\end{array}$ & Oleaceae & Wild olive & Crushed bark is soaked in warm water & Bark & Cattle & Black quarter (Ciko) & Mthi et al., [45] \\
\hline $\begin{array}{l}\text { Osyris lanceolata Hoscht. } \\
\& \text { Steud }\end{array}$ & Santalaceae & Rock tannin-bush & Maceration & Bulb & Cattle & $\begin{array}{l}\text { Retained placenta, } \\
\text { alleviation of pain } \\
\text { and internal bleeding }\end{array}$ & Moichwanetse et al., [43] \\
\hline $\begin{array}{l}\text { Ozoroa paniculosa (Sond.) } \\
\text { R.Fern. \& A.Fern. (Syn: } \\
\text { Ozoroa paniculosa (Sond.) } \\
\text { R.Fern. \& A.Fern. var. } \\
\text { paniculosa) }\end{array}$ & Anacardiaceae & Common resin tree & ns & $\begin{array}{l}\text { Bark, root } \\
\text { bark }\end{array}$ & Cattle & $\begin{array}{l}\text { Diarrhoea, redwater, } \\
\text { sweating sickness }\end{array}$ & Van der Merwe et al., [52] \\
\hline $\begin{array}{l}\text { Peltophorum africanum } \\
\text { Sond. }\end{array}$ & Fabaceae & Weeping wattle & Bark is ground into powder & Bark & Cattle & Wounds & Magwede et al., [39] \\
\hline $\begin{array}{l}\text { Peltophorum africanum } \\
\text { Sond. }\end{array}$ & Fabaceae & Weeping wattle & Poultice & $\begin{array}{l}\text { Leaves } \\
\text { and bulb }\end{array}$ & Cattle & $\begin{array}{l}\text { Retained placenta, } \\
\text { diarrhoea, and } \\
\text { removal of blood } \\
\text { clots from the skin }\end{array}$ & Moichwanetse et al., [43] \\
\hline $\begin{array}{l}\text { Peltophorum africanum } \\
\text { Sond. }\end{array}$ & Fabaceae & Weeping wattle & ns & $\begin{array}{l}\text { Bark, root } \\
\text { bark }\end{array}$ & Cattle & Tonic, diarrhoea & Van der Merwe et al., [52. \\
\hline $\begin{array}{l}\text { Philenoptera violacea } \\
\text { (Klotzsch) Schrire }\end{array}$ & Fabaceae & Apple-leaf & $\begin{array}{l}\text { Bark is ground and infused in } \\
\text { water overnight }\end{array}$ & Bark & Cattle & $\begin{array}{l}\text { Gall, diarrhoea, and } \\
\text { general ailments }\end{array}$ & Khunoana et al., [36] \\
\hline
\end{tabular}


Table 2. Cont.

\begin{tabular}{|c|c|c|c|c|c|c|c|}
\hline Plant Species & Family & Common Name & $\begin{array}{l}\text { Method of Preparation } \\
\text { and Administration }\end{array}$ & $\begin{array}{l}\text { Plant Part } \\
\text { Used }\end{array}$ & $\begin{array}{l}\text { Animal } \\
\text { Treated }\end{array}$ & $\begin{array}{l}\text { Disease/Health } \\
\text { Condition }\end{array}$ & Reference \\
\hline $\begin{array}{l}\text { Philenoptera violacea } \\
\text { (Klotzsch) Schrire }\end{array}$ & Fabaceae & Apple-leaf & Bark is boiled in water & Bark & Cattle & Wounds & Magwede et al., [39] \\
\hline $\begin{array}{l}\text { Philenoptera violacea } \\
\text { (Klotzsch) Schrire }\end{array}$ & Fabaceae & Apple-leaf & $\begin{array}{l}\text { Bark is cooked or soaked in cold water } \\
\text { to produce a red decoction/infusion }\end{array}$ & $\begin{array}{l}\text { Stem and } \\
\text { root-bark }\end{array}$ & Cattle & Redwater & $\begin{array}{l}\text { Ramovha and } \\
\text { Van Wyk [48] }\end{array}$ \\
\hline Phoenix reclinata Jacq. & Arecacea & Wild date palm & $\begin{array}{l}\text { Roots are mixed with Arctotis arctotoides } \\
\text { leaves and boiled, warm liquid is used }\end{array}$ & Roots & $\begin{array}{l}\text { Sheep, } \\
\text { goats }\end{array}$ & Footrot & Dold and Cocks [34] \\
\hline $\begin{array}{l}\text { Pittosporum viridiflorum } \\
\text { Sims }\end{array}$ & Pittosporaceae & Cheesewood & Decoction & Roots & Chicken & Wounds & Soyelu and Masika [51] \\
\hline Pouzolzia mixta Solms & Urticaceae & Soap-nettle & Poultice & Roots & Cattle & $\begin{array}{l}\text { Retained placenta } \\
\text { and uterus cleansing }\end{array}$ & Moichwanetse et al., [43] \\
\hline $\begin{array}{l}\text { Protorhus longifolia } \\
\text { (Bernh.) Engl. }\end{array}$ & Anacardiaceae & Red beech & $\begin{array}{l}\text { Mixed with bark of Hippobromus } \\
\text { pauciflorus and boiled for } 20 \mathrm{~min}\end{array}$ & Bark & Cattle & $\begin{array}{l}\text { Heartwater and } \\
\text { diarrhoea }\end{array}$ & Dold and Cocks [34] \\
\hline Prunus persica (L.) Batsch & Rosaceae & Peach tree & $\begin{array}{l}\text { Ground to pulp and mixed with hot } \\
\text { paper and liquid }\end{array}$ & Leaves & ns & Wounds & Magwede et al., [39] \\
\hline Prunus persica (L.) Batsch & Rosaceae & Peach tree & Infusion & Leaves & Cattle & $\begin{array}{l}\text { Maggot-infested } \\
\text { wounds }\end{array}$ & Soyelu and Masika [51] \\
\hline $\begin{array}{l}\text { Pseudolachnostylis } \\
\text { maprouneifoloia Pax }\end{array}$ & Phyllanthaceae & Kudu berry & Ground bark is mixed with water & Bark & Cattle & Drought tonic & $\begin{array}{l}\text { Luseba and } \\
\text { Tshisikhawe [37] }\end{array}$ \\
\hline $\begin{array}{l}\text { Ptaeroxylon obliquum } \\
\text { (Thunb.) Radlk. }\end{array}$ & Ptaeroxylaceae & Sneezewood & Decoction & Leaves & Goats & $\begin{array}{l}\text { Gastro-intestinal } \\
\text { parasites }\end{array}$ & Maphosa and Masika [41] \\
\hline $\begin{array}{l}\text { Ptaeroxylon obliquum } \\
\text { (Thunb.) Radlk. }\end{array}$ & Ptaeroxylaceae & Sneezewood & $\begin{array}{l}\text { Crushed and soaked in cold water } \\
\text { overnight (infusion) }\end{array}$ & Bark & Cattle & Ticks & Moyo and Masika [44] \\
\hline $\begin{array}{l}\text { Ptaeroxylon obliquum } \\
\text { (Thunb.) Radlk. }\end{array}$ & Ptaeroxylaceae & Sneezewood & $\begin{array}{l}\text { Crush bark is mixed with used oil to } \\
\text { form paste. Leaf decoction }\end{array}$ & $\begin{array}{l}\text { Bark, } \\
\text { leaves }\end{array}$ & Cattle & Wounds and myiasis & Soyelu and Masika [51] \\
\hline $\begin{array}{l}\text { Pterocarpus angolensis } \\
\text { DC. }\end{array}$ & Fabaceae & Paddle-wood & Stem bark infusion & Bark & Cattle & Constipation & Chitura et al., [33] \\
\hline
\end{tabular}


Table 2. Cont

\begin{tabular}{|c|c|c|c|c|c|c|c|}
\hline Plant Species & Family & Common Name & $\begin{array}{l}\text { Method of Preparation } \\
\text { and Administration }\end{array}$ & $\begin{array}{l}\text { Plant Part } \\
\text { Used }\end{array}$ & $\begin{array}{l}\text { Animal } \\
\text { Treated }\end{array}$ & $\begin{array}{l}\text { Disease/Health } \\
\text { Condition }\end{array}$ & Reference \\
\hline $\begin{array}{l}\text { Pterocarpus angolensis } \\
\text { DC. }\end{array}$ & Fabaceae & Paddle-wood & Soak the bark in water & Bark & Cattle & Mali and not eating & $\begin{array}{l}\text { Luseba and } \\
\text { Tshisikhawe [37] }\end{array}$ \\
\hline $\begin{array}{l}\text { Pterocarpus angolensis } \\
\text { DC. }\end{array}$ & Fabaceae & Paddle-wood & $\begin{array}{l}\text { Chopped bark is soaked in cold water } \\
\text { after the water has changed to reddish } \\
\text { boil for } 30-60 \mathrm{~min}\end{array}$ & Bark & ns & $\begin{array}{l}\text { General illness, } \\
\text { unthriftiness, } \\
\text { gallsickness, } \\
\text { intestinal worms, } \\
\text { blackquarter }\end{array}$ & $\begin{array}{l}\text { Luseba and } \\
\text { Van der Merwe [38] }\end{array}$ \\
\hline $\begin{array}{l}\text { Pterocarpus angolensis } \\
\text { DC. }\end{array}$ & Fabaceae & Paddle-wood & Bark is ground to pulp & Bark & Cattle & Wounds & Magwede et al., [39] \\
\hline $\begin{array}{l}\text { Pterocarpus angolensis } \\
\text { DC. }\end{array}$ & Fabaceae & & $\begin{array}{l}\text { Bark is cooked or imbibed in cold water } \\
\text { to produce a red decoction/infusion }\end{array}$ & $\begin{array}{l}\text { Bark, root } \\
\text { bark }\end{array}$ & Cattle & Redwater & $\begin{array}{l}\text { Ramovha and } \\
\text { Van Wyk [48] }\end{array}$ \\
\hline $\begin{array}{l}\text { Rapanea melanophloeos (L.) } \\
\text { Mez (Syn: } \\
\text { Myrsine melanophloeos (L.) } \\
\text { R.Br. ex Sweet) }\end{array}$ & Primulaceae & Cape Beech & $\begin{array}{l}\text { Mixed with bark of Curtisia dentata and } \\
\text { boiled for } 30 \mathrm{~min}\end{array}$ & Bark & Cattle & Heartwater & Dold and Cocks [34] \\
\hline Rhamnus prinoides L'Hér. & Rhamnaceae & Dogwood & Infusion & Roots & Goats & $\begin{array}{l}\text { Twin or triplets } \\
\text { production }\end{array}$ & Rwodzi [49] \\
\hline $\begin{array}{l}\text { Rhoicissus tridentata (L.f.) } \\
\text { Wild \& R.B.Drumm. }\end{array}$ & Vitaceae & $\begin{array}{l}\text { Northern bushman's } \\
\text { grape }\end{array}$ & Tuber is boiled in water for $15 \mathrm{~min}$ & Tubers & $\begin{array}{l}\text { Goats, } \\
\text { sheep }\end{array}$ & Diarrhoea & Dold and Cocks [34] \\
\hline $\begin{array}{l}\text { Rhoicissus tridentata (L.f.) } \\
\text { Wild \& R.B.Drumm. }\end{array}$ & Vitaceae & $\begin{array}{l}\text { Northern bushman's } \\
\text { grape }\end{array}$ & Leaves are boiled & Leaves & Cattle & Lumpy skin disease & $\begin{array}{l}\text { Luseba and } \\
\text { Tshisikhawe [37] }\end{array}$ \\
\hline $\begin{array}{l}\text { Rhoicissus tridentata (L.f.) } \\
\text { Wild \& R.B.Drumm. }\end{array}$ & Vitaceae & $\begin{array}{l}\text { Northern bushman's } \\
\text { grape }\end{array}$ & ns & Tubers & Cattle & $\begin{array}{l}\text { Heartwater, redwater } \\
\text { internal parasites }\end{array}$ & Van der Merwe et al., [52] \\
\hline $\begin{array}{l}\text { Rothmannia capensis } \\
\text { Thunb }\end{array}$ & Rubiaceae & Wild gardenia & Decoction & Roots & Cattle & Eating problem & $\begin{array}{l}\text { Luseba and } \\
\text { Tshisikhawe [37] }\end{array}$ \\
\hline $\begin{array}{l}\text { Rothmannia capensis } \\
\text { Thunb }\end{array}$ & Rubiaceae & Wild gardenia & Fresh fruits are grounded to pulp & Fruit & ns & Wounds & Magwede et al., [39] \\
\hline
\end{tabular}


Table 2. Cont.

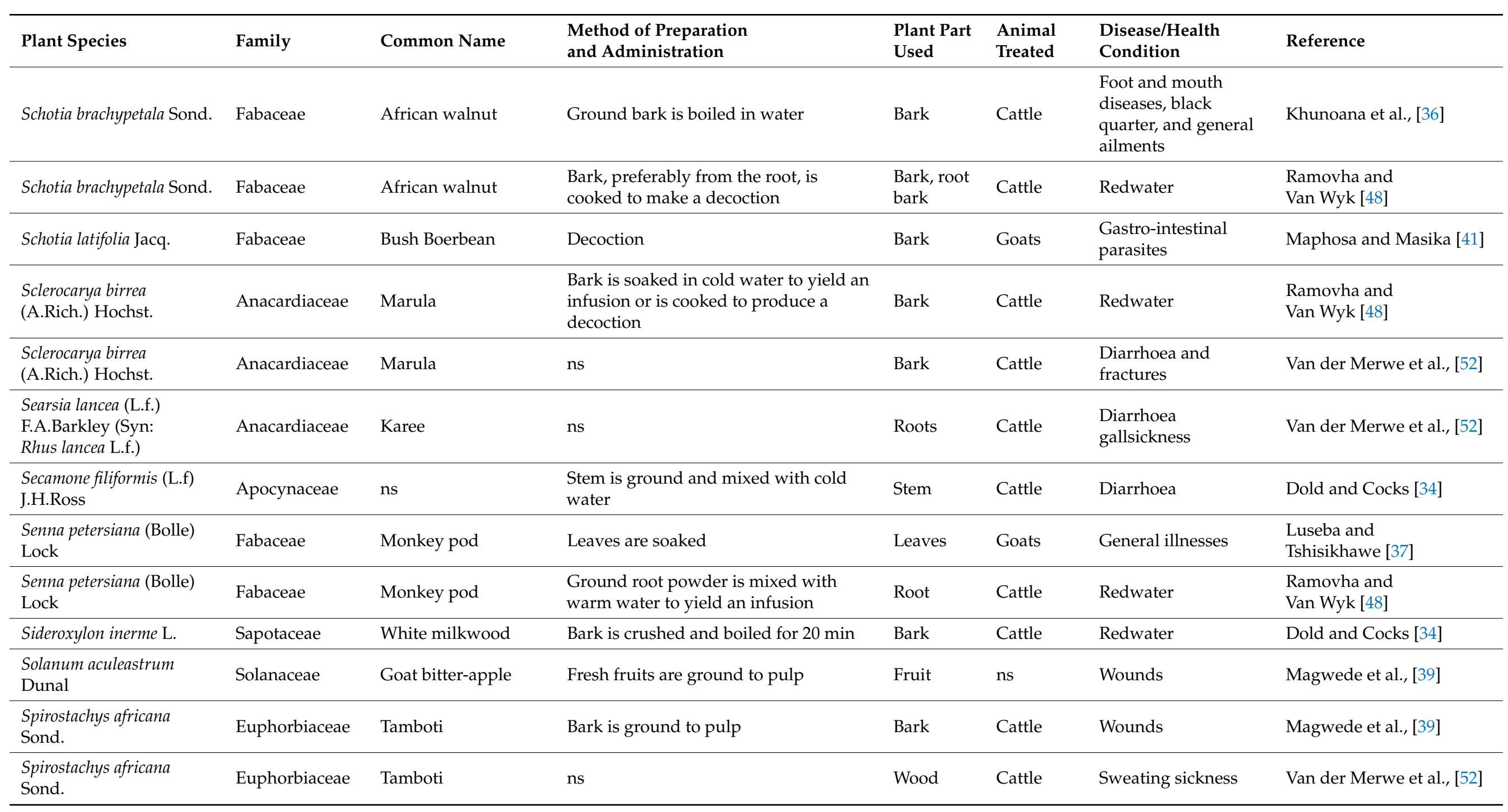


Table 2. Cont.

\begin{tabular}{|c|c|c|c|c|c|c|c|}
\hline Plant Species & Family & Common Name & $\begin{array}{l}\text { Method of Preparation } \\
\text { and Administration }\end{array}$ & $\begin{array}{l}\text { Plant Part } \\
\text { Used }\end{array}$ & $\begin{array}{l}\text { Animal } \\
\text { Treated }\end{array}$ & $\begin{array}{l}\text { Disease/Health } \\
\text { Condition }\end{array}$ & Reference \\
\hline $\begin{array}{l}\text { Strychnos decussata } \\
\text { (Pappe) Gilg. }\end{array}$ & Loganiaceae & Cape teak & $\begin{array}{l}\text { Bark is crushed and soaked in water for } \\
20 \text { min, after which the infusion } \\
\text { is strained }\end{array}$ & Bark & Cattle & Roundworms & Dold and Cocks [34] \\
\hline Strychnos henningsii Gilg & Loganiaceae & Red bitter berry & Resin & ns & $\begin{array}{l}\text { Cattle, } \\
\text { sheep, } \\
\text { goats }\end{array}$ & Arthritis & Chitura et al., [33] \\
\hline Strychnos henningsii Gilg & Loganiaceae & Red bitter berry & Decoction & Bark & Goats & $\begin{array}{l}\text { Gastro-intestinal } \\
\text { parasites }\end{array}$ & Maphosa and Masika [41] \\
\hline Strychnos henningsii Gilg & Loganiaceae & Red bitter berry & ns & Bark & Cattle & Paratyphoid (Goso) & Mthi et al., [45] \\
\hline $\begin{array}{l}\text { Tabernaemontana elegans } \\
\text { Stapf }\end{array}$ & Apocynaceae & Toad tree & $\begin{array}{l}\text { Crushed or in tact roots are soaked in } \\
\text { water to yield an infusion or are cooked } \\
\text { to produce a decoction }\end{array}$ & Roots & Cattle & Redwater & $\begin{array}{l}\text { Ramovha and } \\
\text { Van Wyk [48] }\end{array}$ \\
\hline $\begin{array}{l}\text { Tarchonanthus } \\
\text { camphoratus L. }\end{array}$ & Asteraceae & Camphor bush & $\begin{array}{l}\text { Leaf infusion, oral route: The leaves of } \\
\text { the plant are put in drinking water }\end{array}$ & Leaves & ns & To prevent cold & Ndou [47] \\
\hline $\begin{array}{l}\text { Terminalia sericea Burch. } \\
\text { ex DC. }\end{array}$ & Combretaceae & Silver cluster-leaf & $\begin{array}{l}\text { Ground roots are mixed with water to } \\
\text { apply on the ticks and wounds. Roots } \\
\text { are boiled and given to the animal }\end{array}$ & Roots & Cattle & $\begin{array}{l}\text { Ticks and wounds, } \\
\text { diarrhoea }\end{array}$ & $\begin{array}{l}\text { Luseba and } \\
\text { Tshisikhawe [37] }\end{array}$ \\
\hline $\begin{array}{l}\text { Terminalia sericea Burch. } \\
\text { ex DC. }\end{array}$ & Combretaceae & Silver cluster-leaf & $\begin{array}{l}\text { Ground leaves are mixed with water } \\
\text { and applied on the wound and are } \\
\text { covered with cattle dung }\end{array}$ & Leaves & Cattle & Wounds & $\begin{array}{l}\text { Luseba and } \\
\text { Van der Merwe [38] }\end{array}$ \\
\hline $\begin{array}{l}\text { Terminalia sericea Burch. } \\
\text { ex DC. }\end{array}$ & Combretaceae & Silver cluster-leaf & $\begin{array}{l}\text { Roots are ground to pulp and mixed } \\
\text { with water }\end{array}$ & Roots & Cattle & Wounds and ticks & Magwede et al., [39] \\
\hline $\begin{array}{l}\text { Terminalia sericea Burch. } \\
\text { ex DC. }\end{array}$ & Combretaceae & Silver cluster-leaf & Poultice & Leaves & Cattle & $\begin{array}{l}\text { Retained placenta } \\
\text { and uterus cleansing }\end{array}$ & Moichwanetse et al., [43] \\
\hline
\end{tabular}


Table 2. Cont.

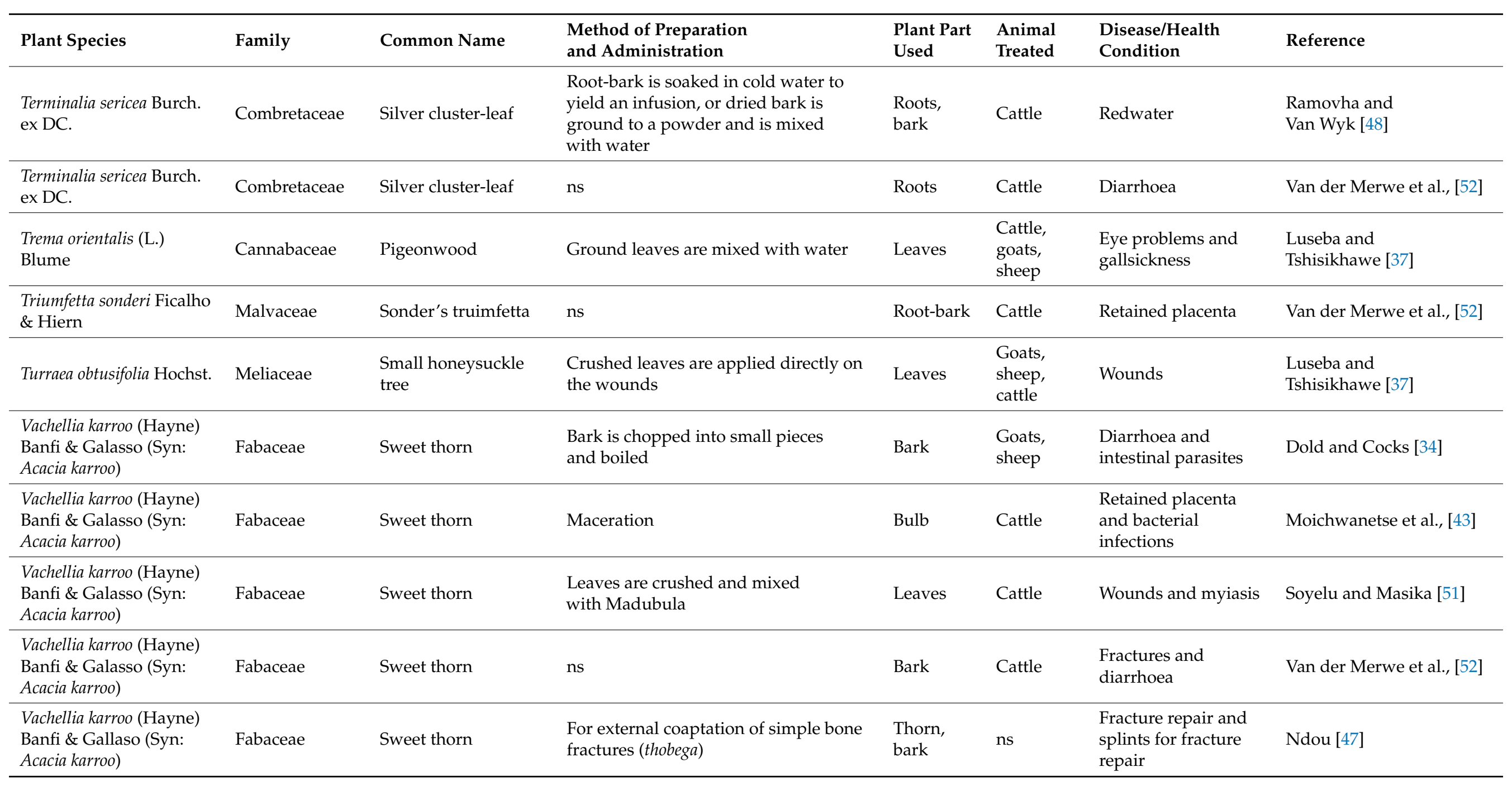


Table 2. Cont

\begin{tabular}{|c|c|c|c|c|c|c|c|}
\hline Plant Species & Family & Common Name & $\begin{array}{l}\text { Method of Preparation } \\
\text { and Administration }\end{array}$ & $\begin{array}{l}\text { Plant Part } \\
\text { Used }\end{array}$ & $\begin{array}{l}\text { Animal } \\
\text { Treated }\end{array}$ & $\begin{array}{l}\text { Disease/Health } \\
\text { Condition }\end{array}$ & Reference \\
\hline $\begin{array}{l}\text { Vachellia tortilis (Forssk.) } \\
\text { Galasso \& Banfi (Syn: } \\
\text { Acacia tortilis) }\end{array}$ & Fabaceae & Umbrella thorn & ns & $\begin{array}{l}\text { Branch } \\
\text { tips }\end{array}$ & Cattle & Diarrhoea & Van der Merwe et al., [52] \\
\hline $\begin{array}{l}\text { Volkameria glabra (E.Mey.) } \\
\text { Mabb. \& Y.W.Yuan (Syn: } \\
\text { Clerodendrum capense } \\
\text { D.Don ex Steud.) }\end{array}$ & Lamiaceae & Tinderwood & ns & Leaves & ns & Worms & Kambizi [35] \\
\hline $\begin{array}{l}\text { Withania somnifera (L.) } \\
\text { Dunal }\end{array}$ & Solanaceae & winter cherry & $\begin{array}{l}\text { Tuber infusion combined with roots of } \\
\text { Solanum lichtensteinii and Bulbine } \\
\text { abyssinica, oral route }\end{array}$ & Tubers & ns & Internal sores & Ndou [47] \\
\hline $\begin{array}{l}\text { Xanthocercis zambesiaca } \\
\text { (Baker) Dumaz-le-Grand }\end{array}$ & Fabaceae & Nyala tree & $\begin{array}{l}\text { Ground bark is given to cattle for eating } \\
\text { disorders. Ground bark is mixed with } \\
\text { salt or leaves are soaked for } 12 \mathrm{~h}\end{array}$ & $\begin{array}{l}\text { Bark, } \\
\text { leaves }\end{array}$ & Cattle & $\begin{array}{l}\text { Eating problem and } \\
\text { diarrhoea }\end{array}$ & $\begin{array}{l}\text { Luseba and } \\
\text { Tshisikhawe [37] }\end{array}$ \\
\hline $\begin{array}{l}\text { Xanthocercis zambesiaca } \\
\text { (Baker) Dumaz-le-Grand }\end{array}$ & Fabaceae & Nyala tree & Ground bark is applied topically & Bark & ns & Wounds & Magwede et al., [39] \\
\hline $\begin{array}{l}\text { Ximenia americana L. var. } \\
\text { microphylla Welw. ex } \\
\text { Oliv. }\end{array}$ & Olacaceae & Tallowwood & ns & Roots & Cattle & Internal parasites & Van der Merwe et al., [52] \\
\hline $\begin{array}{l}\text { Zanthoxylum capense } \\
\text { (Thunb.) Harv. }\end{array}$ & Rutaceae & Small knobwood & $\begin{array}{l}\text { Infusion prepared Grewia occidentalis, } \\
\text { Olea europaea subsp. africana leaves and } \\
\text { Aloe ferox sap }\end{array}$ & Leaves & ns & Gallsickess & Dold and Cocks [34] \\
\hline $\begin{array}{l}\text { Zanthoxylum capense } \\
\text { (Thunb.) Harv. }\end{array}$ & Rutaceae & Small knobwood & Decoction & Roots & Goats & $\begin{array}{l}\text { Gastro-intestinal } \\
\text { parasites }\end{array}$ & Maphosa and Masika [41] \\
\hline Ziziphus mucronata Willd. & Rhamnaceae & Buffalo thorn & Leaf paste & Leaves & Cattle & Mastitis & Chitura et al., [33] \\
\hline
\end{tabular}


Table 2. Cont

\begin{tabular}{|c|c|c|c|c|c|c|c|}
\hline Plant Species & Family & Common Name & $\begin{array}{l}\text { Method of Preparation } \\
\text { and Administration }\end{array}$ & $\begin{array}{l}\text { Plant Part } \\
\text { Used }\end{array}$ & $\begin{array}{l}\text { Animal } \\
\text { Treated }\end{array}$ & $\begin{array}{l}\text { Disease/Health } \\
\text { Condition }\end{array}$ & Reference \\
\hline Ziziphus mucronata Willd. & Rhamnaceae & Buffalo thorn & $\begin{array}{l}\text { Bark is soaked in water while leaves are } \\
\text { ground into pulp }\end{array}$ & $\begin{array}{l}\text { Bark and } \\
\text { leaves }\end{array}$ & ns & Wound & Magwede et al., [39] \\
\hline Ziziphus mucronata Willd. & Rhamnaceae & Buffalo thorn & Infusion & Roots & Goats & $\begin{array}{l}\text { Gastro-intestinal } \\
\text { parasites }\end{array}$ & Maphosa and Masika [41] \\
\hline Ziziphus mucronata Willd. & Rhamnaceae & Buffalo thorn & Poultice & Roots & Cattle & Retained placenta & Moichwanetse et al., (2020) \\
\hline Ziziphus mucronata Willd. & Rhamnaceae & Buffalo thorn & $\begin{array}{l}\text { Crushed leaves and soft branches } \\
\text { poultice: crushed and placed on a } \\
\text { hard abscess }\end{array}$ & $\begin{array}{l}\text { Leaves, } \\
\text { branches }\end{array}$ & ns & Abscess ripening & Ndou [47] \\
\hline Ziziphus mucronata Willd. & Rhamnaceae & Buffalo thorn & ns & $\begin{array}{l}\text { Leaves, } \\
\text { roots }\end{array}$ & Cattle & $\begin{array}{l}\text { Fertility } \\
\text { enhancement, sores } \\
\text { and burns }\end{array}$ & Van der Merwe et al., [52] \\
\hline $\begin{array}{l}\text { Ziziphus oxyphylla Edgew } \\
\text { (Syn: Ziziphus acuminata } \\
\text { Royle) }\end{array}$ & Rhamnaceae & Pointed-leaf jujube & Poultice & Roots & Cattle & $\begin{array}{l}\text { Retained placenta } \\
\text { and increase } \\
\text { stimulation for } \\
\text { separating retained } \\
\text { placenta }\end{array}$ & Moichwanetse et al., [43] \\
\hline Ziziphus zeyheriana Sond. & Rhamnaceae & Dwarf buffalo-thorn & ns & $\begin{array}{l}\text { Root- } \\
\text { stock }\end{array}$ & ns & $\begin{array}{l}\text { Diarrhoea internal } \\
\text { parasites. General } \\
\text { ailments }\end{array}$ & $\begin{array}{l}\text { Luseba and } \\
\text { Van der Merwe [38] }\end{array}$ \\
\hline Ziziphus zeyheriana Sond. & Rhamnaceae & Dwarf buffalo-thorn & $\begin{array}{l}\text { Root decoction: Combined with roots of } \\
\text { Cadaba aphylla, Senna italica and } \\
\text { Dicoma galpinii. Root decoction } \\
\text { combined with root of } \\
\text { Helichrysum caespititium. Root decoction } \\
\text { combined with root of Grewia flava, oral } \\
\text { route. The sick calf is given about half a } \\
\text { litre of the decoction orally }\end{array}$ & Roots & Cattle & $\begin{array}{l}\text { Blood cleansing, } \\
\text { pains (from sores, } \\
\text { fractures), calf } \\
\text { diarrhoea }\end{array}$ & Ndou [47] \\
\hline
\end{tabular}


In terms of plant families (Figure 1), most of the identified plants were from the Fabaceae (19\%), Apocynaceae (5.8\%), Rubiaceae (5.8\%), Anacardiaceae $(4.8 \%)$, Combretaceae $(4.8 \%)$, Euphorbiaceae (4.8\%), Malvaceae $(4.8 \%)$, Rhamnaceae $(4.8 \%)$, and Celastraceae $(3.8 \%)$ families. Even though 44 families were recorded, the majority (estimated $64 \%$ ) of the families were represented by one woody plant. Based on the analysis of approximately 4576 vascular plants representing 192 families (from the 254 African families) with medicinal value in sub-Saharan African, the dominance of Fabaceae remains evident in African traditional medicine [58]. Furthermore, Fabaceae was the most represented plant family for plants used against cattle diseases in South Africa [59].

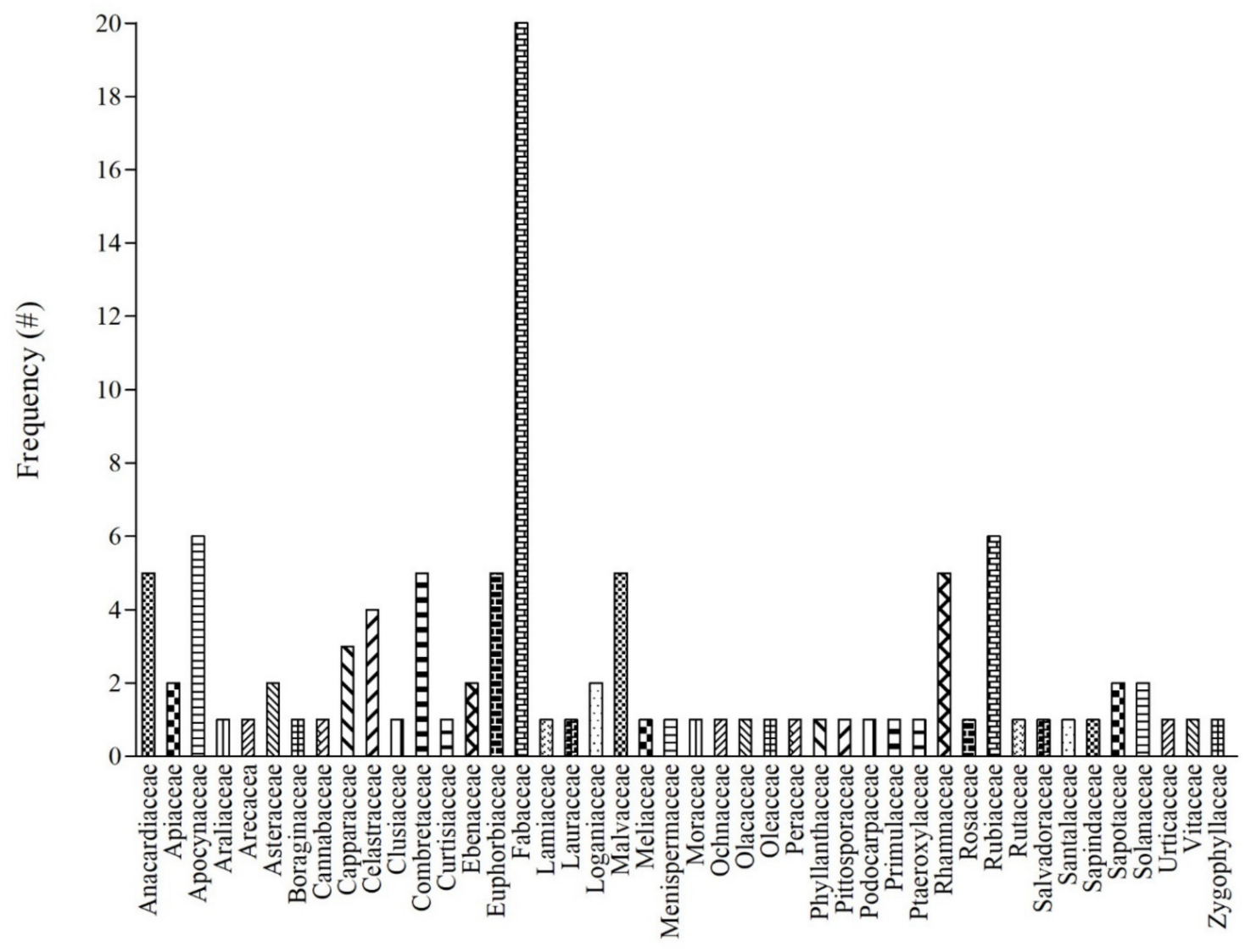

Plant family

Figure 1. Frequency of the 44 families of woody plants used in South African ethnoveterinary medicine. \# = number of mention.

Plant parts used to prepare herbal remedies included bark, leaves, fruits, roots, and flowers (Figure 2). However, the most commonly used plant parts for remedy preparations were bark (33\%) followed by leaves $(29 \%)$ and roots $(19 \%)$. The dominance of plant parts such as bark and roots may not be sustainable overtime, as their indiscriminate harvesting is often of great conservation concerns for the survival of the plant [26]. Thus, conscious efforts remain essential to ensure good harvesting practices and the long-term sustainability of these valuable woody plants.

\subsection{Overview of Animals/Livestock and Diseases}

As shown in Figure 3, cattle were the major (61\%) animal/livestock treated with the woody plants. In South Africa, the importance of cattle among different cultural groups cannot be overemphasized [1,59]. Van der Merwe et al., [52] documented the use of ethnoveterinary medicinal plants in cattle by the Setswana-speaking people in the Madikwe 
area of the North West Province. The most important diseases treated were retained placenta, diarrhoea, fractures, fertility enhancement, general gastrointestinal problems, and pneumonia. A high proportion of the woody plants were used for diarrhoea. Some of the plants documented during the study are used elsewhere in the Eastern Cape to treat different livestock diseases. These include Vachellia karroo, Vachellia tortilis, Cussonia spicata, Rhoicissus tridentata, and Ziziphus mucronata.

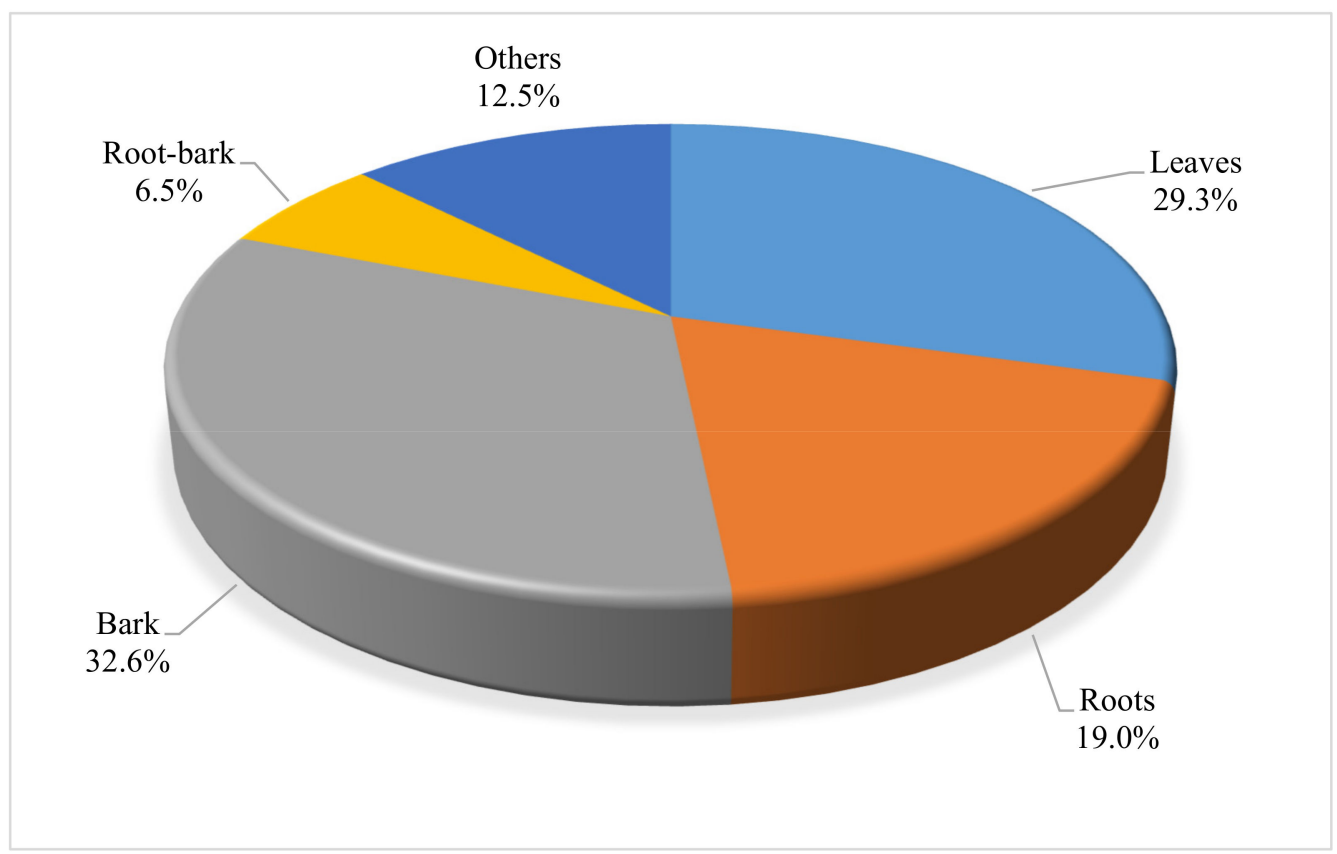

Figure 2. Distribution of different parts of woody plants used in the preparation of ethnoveterinary remedies in South Africa. Others denote parts such as seeds, fruits, flowers, and twigs. $(n=184)$.

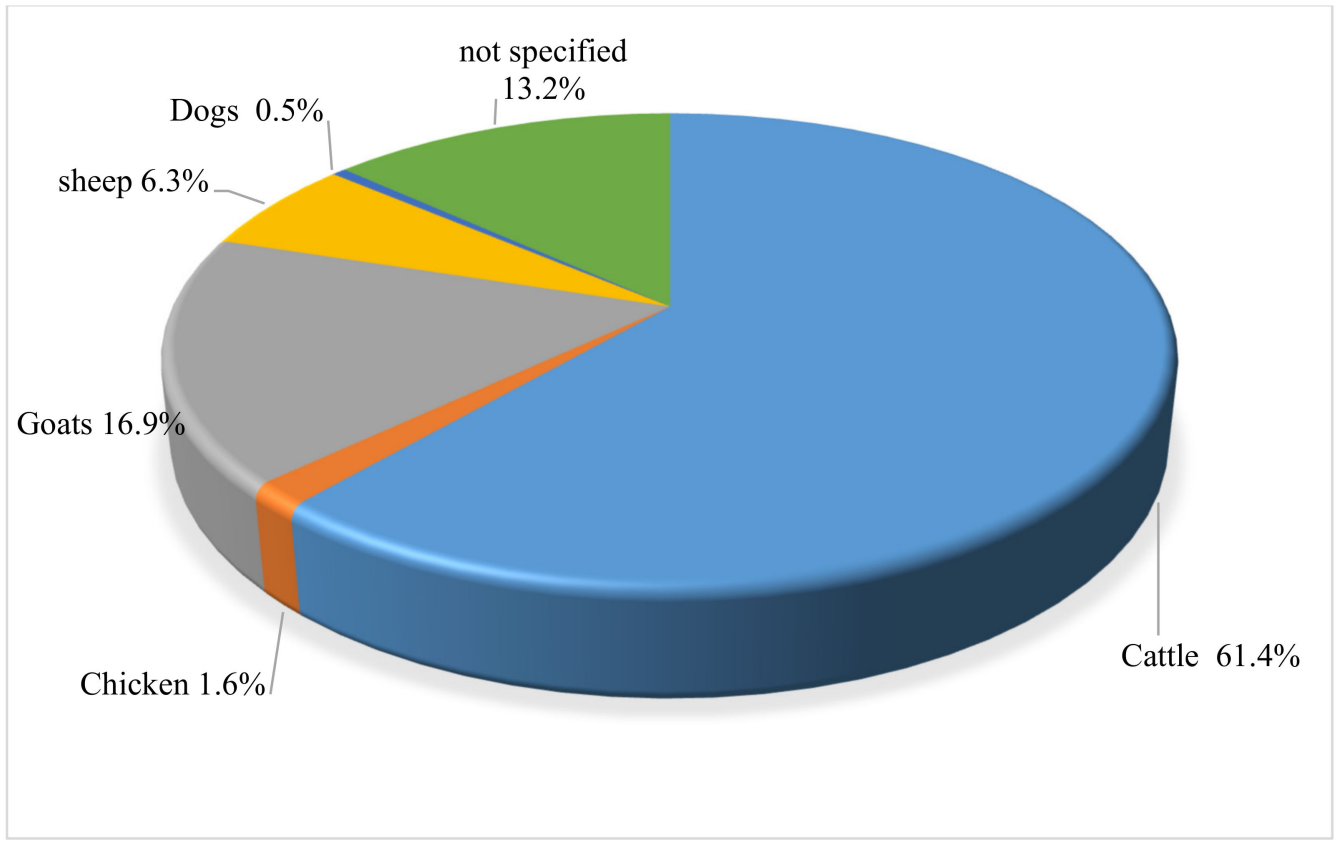

Figure 3. Distribution of animals identified in ethnoveterinary surveys for woody plants in South Africa. $(n=189)$. 


\subsection{In Vitro Biological Screening of Woody Plants}

The increasing incidence of drug resistance in most pathogenic bacteria and parasites that cause economic loss in animals/livestock production calls for the development of new sources for medication [60,61]. Among to the 104 woody plants with ethnoveterinary uses in South Africa (Table 2), approximately 20\% were screened for their relevant biological activities (e.g., antibacterial, anthelmintic, and antioxidant) and safety (cytotoxicity) level. However, the current review included woody plants that have been screened for biological activities without evidence of their ethnoveterinary use in South Africa. This approach may increase the success rate of bio-prospecting for therapeutic woody plants for ethnoveterinary needs in South Africa [62]. As highlighted by Eloff [63], no statistically significant difference was observed in the antimicrobial activity of plants with ethnobotanical knowledge when compared to randomly selected plants. Hence, the most promising biological activity may not correlate with the most popular plants with existing ethnobotanical knowledge [62,64].

\subsubsection{Antibacterial Activity}

Even though the antibacterial effects of 39 woody plants were reported (Table 3), approximately $56 \%$ of the 39 plants lacked ethnoveterinary applications in the eligible studies that were recorded (Tables 1 and 2). In terms of the assay-type, approximately 95\% of the studies were conducting using the micro-plate dilution method, which is considered as a more robust and reliable assay relative to agar diffusion $[63,64]$. Based on the recorded antibacterial activity (Table 3), Gram-positive bacteria were more dominant (57\% of the 14 organisms) than Gram-negative bacterial strains. Although a diverse range of bacterial strains was tested, the relevance and justification for their selection were unclear in most of the studies. Researchers need to be cognizant of the bacteria type in order to demonstrate the clinical relevance of the anti-bacterial effect of the tested plant extracts $[64,65]$.

On the basis on the number of reports, five woody plants namely Alsophila dregei (Kunze) R.M.Tryon, Cussonia spicata Thunb, Indigofera frutescens L.f., Leucosidea sericea Eckl. and Zeyh, and Maesa lanceolata Forssk were the most studied woody plants in terms of their antibacterial effects (Table 3). The most noteworthy (MIC $=20-40 \mu \mathrm{g} / \mathrm{mL}$ ) antibacterial effect (exerted against Bacillus anthracis) was demonstrated by acetone extracts of Bolusanthus speciosus (Bolus) Harms, Morus mesozygia Stapf, and Maesa lanceolata Forssk [66]. Likewise, Salmonella typhimurium was highly susceptible (MIC $=40 \mu \mathrm{g} / \mathrm{mL}$ ) to acetone extracts from Crotalaria capensis leaves [67]. Furthermore, the acetone extract from Maesa lanceolata leaves exerted a broad-spectrum antibacterial effect by significantly (MIC $=160-630 \mu \mathrm{g} / \mathrm{mL}$ ) inhibiting both Gram-positive (Enterococcus faecalis, Staphylococcus aureus) and Gram-negative (Escherichia coli, Pseudomonas aeruginosa, Salmonella typhimurium) bacterial strains [68]. Similar broad-spectrum antibacterial activity was demonstrated by the acetone leaf extracts of Indigofera frutescens L.f. (MIC $=80-310 \mu \mathrm{g} / \mathrm{mL}$ ) and Leucosidea sericea (MIC $=20-80 \mu \mathrm{g} / \mathrm{mL}$ ), as indicated by different authors [67-69].

Leaves/aerial parts $(77 \%)$ and bark $(17 \%)$ were the most common parts of the woody plants that were evaluated for their antibacterial activity. Remarkable differences in the antibacterial effect of woody plant parts were evident in Leucosidea sericea [69], Schotia brachypetala Sond, Searsia lancea (L.f.) F.A.Barkley (Rhus lanceas), and Ziziphus mucronata Willd [70]. Particularly in Schotia brachypetala and Ziziphus mucronata, the leaf extracts had remarkable antibacterial effects against the tested bacterial strains while the bark extracts were ineffective. Furthermore, the type of solvent used for extracting the plant parts strongly influenced the resultant antibacterial response (Table 3). Despite the popularity of water as the most commonly used solvent in traditional medicine, water extracts often exhibit weaker antibacterial effects relative to many organic solvents [63]. 


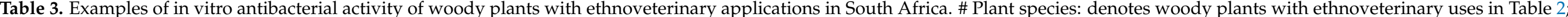
MIC-minimum inhibitory concentration, ns-not specified.

\begin{tabular}{|c|c|c|c|c|c|c|c|}
\hline \# Plant Species & Plant Part & Solvent & Test System & Test Organism & Positive Control & Findings & Reference \\
\hline Acokanthera oppositifolia & Leaves & $\begin{array}{l}\text { Petroleum ether, } \\
\text { dichloromethane, } \\
\text { ethanol, and water }\end{array}$ & $\begin{array}{l}\text { Serial } \\
\text { microplate } \\
\text { dilution }\end{array}$ & $\begin{array}{l}\text { Bacillus subtilis, } \\
\text { Staphylococcus aureus, } \\
\text { Escherichia coli and } \\
\text { Klebsiella pneumoniae }\end{array}$ & Neomycin $(0.39-1.56$ ㅆg/mL) & $\begin{array}{l}\text { All extract had } \\
\text { no noteworthy } \\
\text { (MIC }>1 \mathrm{mg} / \mathrm{mL}) \\
\text { antibacterial effect }\end{array}$ & Aremu et al., [71] \\
\hline $\begin{array}{l}\text { Alsophila dregei (Kunze) } \\
\text { R.M.Tryon (Syn: } \\
\text { Cyathea dregei) }\end{array}$ & Leaves & Acetone & $\begin{array}{l}\text { Serial } \\
\text { microplate } \\
\text { dilution }\end{array}$ & $\begin{array}{l}\text { Escherichia coli, } \\
\text { Enterococcus faecalis, } \\
\text { Pseudomonas aeruginosa, } \\
\text { and Staphylococcus aureus }\end{array}$ & Gentamicin $\leq 0.02 \mathrm{mg} / \mathrm{mL}$ & $\begin{array}{l}\text { Moderate antibacterial } \\
\text { activity with } \\
\text { MIC }=0.63 \mathrm{mg} / \mathrm{mL}\end{array}$ & Adamu et al., [68] \\
\hline $\begin{array}{l}\text { Alsophila dregei (Kunze) } \\
\text { R.M.Tryon (Syn: } \\
\text { Cyathea dregei) }\end{array}$ & $\begin{array}{l}\text { Leaves, } \\
\text { roots }\end{array}$ & $\begin{array}{l}\text { Petroleum ether, } \\
\text { dichloromethane, } \\
\text { ethanol, and water }\end{array}$ & $\begin{array}{l}\text { Serial } \\
\text { microplate } \\
\text { dilution }\end{array}$ & $\begin{array}{l}\text { Bacillus subtilis, } \\
\text { Staphylococcus aureus, } \\
\text { Escherichia coli and } \\
\text { Klebsiella pneumoniae }\end{array}$ & Neomycin $(0.39-1.56$ ㅆg/mL) & $\begin{array}{l}\text { Petroleum ether and } \\
\text { ethanol root extracts had } \\
\text { noteworthy antibacterial } \\
\text { activity }(\mathrm{MIC}<1 \mathrm{mg} / \mathrm{mL} \text { ) } \\
\text { against Gram-positive } \\
\text { bacteria }\end{array}$ & Aremu et al., [71] \\
\hline $\begin{array}{l}\text { Apodytes dimidiata E.Mey. } \\
\text { ex Arn. }\end{array}$ & Leaves & Acetone & $\begin{array}{l}\text { Serial } \\
\text { microplate } \\
\text { dilution }\end{array}$ & $\begin{array}{l}\text { Escherichia coli, } \\
\text { Enterococcus faecalis, } \\
\text { Pseudomonas aeruginosa, } \\
\text { and Staphylococcus aureus }\end{array}$ & Gentamicin $\leq 0.02 \mathrm{mg} / \mathrm{mL}$ & $\begin{array}{l}\text { Moderate antibacterial } \\
\text { activity with } \\
\text { MIC }=0.31 \mathrm{mg} / \mathrm{mL} \\
\text { against } \\
\text { Staphylococcus aureus and } \\
\text { Pseudomonas aeruginosa }\end{array}$ & Adamu et al., [68] \\
\hline $\begin{array}{l}\text { Baphia racemosa (Hochst.) } \\
\text { Baker }\end{array}$ & Leaves & Acetone & $\begin{array}{l}\text { Serial } \\
\text { microplate } \\
\text { dilution }\end{array}$ & $\begin{array}{l}\text { Staphylococcus aureus, } \\
\text { Enterococcus faecalis, } \\
\text { Bacillus cereus, } \\
\text { Escherichia coli, } \\
\text { Pseudomonas aeruginosa, } \\
\text { and } \\
\text { Salmonella typhimurium }\end{array}$ & Gentamicin $=0.2-1.56 \mu \mathrm{g} / \mathrm{mL}$ & $\begin{array}{l}\text { Noteworthy effect against } \\
\text { Enterococcus faecalis } \\
(\mathrm{MIC}=160 \mu \mathrm{g} / \mathrm{mL}) \text { and } \\
\text { Staphylococcus aureus } \\
(\mathrm{MIC}=310 \mu \mathrm{g} / \mathrm{mL})\end{array}$ & Dzoyem et al., [67] \\
\hline $\begin{array}{l}\text { Berchemia zeyheri (Sond.) } \\
\text { Grubov }\end{array}$ & Bark & $\begin{array}{l}\text { Hexane, methanol, } \\
\text { and water }\end{array}$ & $\begin{array}{l}\text { Serial } \\
\text { microplate } \\
\text { dilution } \\
\text { method }\end{array}$ & $\begin{array}{l}\text { Escherichia coli, } \\
\text { Enterococcus faecalis, } \\
\text { Pseudomonas aeruginosa, } \\
\text { and Staphylococcus aureus }\end{array}$ & Neomycin $(0.78-25 \mu \mathrm{M})$ & $\begin{array}{l}\text { Staphylococcus aureus was } \\
\text { susceptible } \\
(\mathrm{MIC}<1 \mathrm{mg} / \mathrm{mL}) \text { to } \\
\text { hexane and } \\
\text { methanol extracts }\end{array}$ & McGaw et al., [70] \\
\hline
\end{tabular}


Table 3. Cont

\begin{tabular}{|c|c|c|c|c|c|c|c|}
\hline \# Plant Species & Plant Part & Solvent & Test System & Test Organism & Positive Control & Findings & Reference \\
\hline $\begin{array}{l}\text { \# Bolusanthus speciosus } \\
\text { (Bolus) Harms }\end{array}$ & Leaves & Acetone & $\begin{array}{l}\text { Serial } \\
\text { microplate } \\
\text { dilution }\end{array}$ & Bacillus anthracis & Gentamicin $=0.0002 \mathrm{mg} / \mathrm{mL}$ & $\mathrm{MIC}=0.04 \mathrm{mg} / \mathrm{mL}$ & Elisha et al., [66] \\
\hline $\begin{array}{l}\text { \# Calpurnia aurea (Aiton) } \\
\text { Benth. }\end{array}$ & Leaves & Acetone & $\begin{array}{l}\text { Serial } \\
\text { microplate } \\
\text { dilution }\end{array}$ & Bacillus anthracis & Gentamicin $=0.0002 \mathrm{mg} / \mathrm{mL}$ & $\mathrm{MIC}=0.31 \mathrm{mg} / \mathrm{mL}$ & Elisha et al., [66] \\
\hline $\begin{array}{l}\text { Clausena anisata (Willd.) } \\
\text { Hook.f. ex. Benth. }\end{array}$ & Leaves & Acetone & $\begin{array}{l}\text { Serial } \\
\text { microplate } \\
\text { dilution }\end{array}$ & $\begin{array}{l}\text { Escherichia coli, } \\
\text { Enterococcus faecalis, } \\
\text { Pseudomonas aeruginosa, } \\
\text { and Staphylococcus aureus }\end{array}$ & Gentamicin $\leq 0.02 \mathrm{mg} / \mathrm{mL}$ & $\begin{array}{l}\text { Noteworthy antibacterial } \\
\text { activity } \\
(\mathrm{MIC}=0.16-0.31 \mathrm{mg} / \mathrm{mL})\end{array}$ & Adamu et al., [68] \\
\hline $\begin{array}{l}\text { Combretum caffrum Eckl. \& } \\
\text { Zeyh.) Kuntze }\end{array}$ & Bark & $\begin{array}{l}\text { Acetone, } \\
\text { methanol, and } \\
\text { water }\end{array}$ & Agar plate & $\begin{array}{l}\text { Escherichia coli, } \\
\text { Pseudomonas aeruginosa, } \\
\text { Staphylococcus aureus, } \\
\text { Bacillus cereus, } \\
\text { Bacillus pumilus, } \\
\text { Bacillus subtilis, } \\
\text { Micrococcus kristinae, } \\
\text { Klebsiella pneumonia, } \\
\text { Serratia marcescens, and } \\
\text { Enterobacter cloacae }\end{array}$ & ns & $\begin{array}{l}\text { Methanol extract inhibited } \\
\text { both Gram-positive and } \\
\text { Gram-negative bacteria } \\
\text { ranging from } \\
0.5-5 \mathrm{mg} / \mathrm{mL} \text {. Acetone } \\
\text { extract mainly inhibited } \\
\text { (MIC }=0.5 \mathrm{mg} / \mathrm{mL}) \\
\text { Gram-positive bacterial } \\
\text { strains. Water extract } \\
\text { showed activity against } \\
\text { five Gram-positive and one } \\
\text { Gram-negative bacteria }\end{array}$ & $\begin{array}{l}\text { Masika and } \\
\text { Afolayan [72] }\end{array}$ \\
\hline $\begin{array}{l}\text { Cremaspora triflora } \\
\text { (Thonn.) K.Schum. }\end{array}$ & Leaves & Acetone & $\begin{array}{l}\text { Serial } \\
\text { microplate } \\
\text { dilution }\end{array}$ & Bacillus anthracis & Gentamicin $=0.0002 \mathrm{mg} / \mathrm{mL}$ & $\mathrm{MIC}=0.16 \mathrm{mg} / \mathrm{mL}$ & Elisha et al., [66] \\
\hline Crotalaria capensis Jacq. & Leaves & Acetone & $\begin{array}{l}\text { Serial } \\
\text { microplate } \\
\text { dilution }\end{array}$ & $\begin{array}{l}\text { Staphylococcus aureus, } \\
\text { Enterococcus faecalis, } \\
\text { Bacillus cereus, } \\
\text { Escherichia coli, } \\
\text { Pseudomonas aeruginosa, } \\
\text { and } \\
\text { Salmonella typhimurium }\end{array}$ & Gentamicin $=0.2-1.56 \mu \mathrm{g} / \mathrm{mL}$ & $\begin{array}{l}\text { Noteworthy effect against } \\
\text { Enterococcus faecalis } \\
(\mathrm{MIC}=80 \mu \mathrm{g} / \mathrm{mL}) \text { and } \\
\text { Salmonella typhimurium } \\
(\mathrm{MIC}=20 \mu \mathrm{g} / \mathrm{mL})\end{array}$ & Dzoyem et al., [67] \\
\hline
\end{tabular}


Table 3. Cont

\begin{tabular}{|c|c|c|c|c|c|c|c|}
\hline \# Plant Species & Plant Part & Solvent & Test System & Test Organism & Positive Control & Findings & Reference \\
\hline \# Cussonia spicata Thunb. & Bark & $\begin{array}{l}\text { Methanol and } \\
\text { dichloromethane }\end{array}$ & $\begin{array}{l}\text { Serial } \\
\text { microplate } \\
\text { dilution }\end{array}$ & $\begin{array}{l}\text { Escherichia coli, } \\
\text { Pseudomonas aeruginosa, } \\
\text { and Staphylococcus aureus }\end{array}$ & Neomycin $=0.1 \mathrm{mg} / \mathrm{mL}$ & $\begin{array}{l}\text { No noteworthy } \\
\text { antibacterial activity }\end{array}$ & Luseba et al., [73] \\
\hline \# Cussonia spicata Thunb. & Root & $\begin{array}{l}\text { Hexane, methanol, } \\
\text { and water }\end{array}$ & $\begin{array}{l}\text { Serial } \\
\text { microplate } \\
\text { dilution }\end{array}$ & $\begin{array}{l}\text { Escherichia coli, } \\
\text { Enterococcus faecalis, } \\
\text { Pseudomonas aeruginosa, } \\
\text { and Staphylococcus aureus }\end{array}$ & Neomycin $(0.78-25 \mu \mathrm{M})$ & $\begin{array}{l}\text { No noteworthy } \\
(\mathrm{MIC}>1 \mathrm{mg} / \mathrm{mL}) \\
\text { antibacterial effects for all } \\
\text { of the tested extracts }\end{array}$ & McGaw et al., [70] \\
\hline $\begin{array}{l}\text { \# Dombeya rotundifolia } \\
\text { (Hochst.) Planch. }\end{array}$ & $\begin{array}{l}\text { Aerial } \\
\text { part }\end{array}$ & $\begin{array}{l}\text { Hexane, methanol, } \\
\text { and water }\end{array}$ & $\begin{array}{l}\text { Serial } \\
\text { microplate } \\
\text { dilution }\end{array}$ & $\begin{array}{l}\text { Escherichia coli, } \\
\text { Enterococcus faecalis, } \\
\text { Pseudomonas aeruginosa, } \\
\text { and Staphylococcus aureus }\end{array}$ & Neomycin $(0.78-25 \mu \mathrm{M})$ & $\begin{array}{l}\text { Methanol extract had } \\
\text { noteworthy } \\
(\mathrm{MIC}=0.4 \mathrm{mg} / \mathrm{mL}) \\
\text { antibacterial effect against } \\
\text { Gram-positive bacteria }\end{array}$ & McGaw et al., [70] \\
\hline $\begin{array}{l}\text { Elaeodendron croceum } \\
\text { (Thunb.) DC. }\end{array}$ & Leaves & Acetone & $\begin{array}{l}\text { Serial } \\
\text { microplate } \\
\text { dilution }\end{array}$ & Bacillus anthracis & Gentamicin $=0.0002 \mathrm{mg} / \mathrm{mL}$ & $\mathrm{MIC}=0.31 \mathrm{mg} / \mathrm{mL}$ & Elisha et al., [66] \\
\hline Erythrina caffra Thunb. & Leaves & Acetone & $\begin{array}{l}\text { Serial } \\
\text { microplate } \\
\text { dilution }\end{array}$ & $\begin{array}{l}\text { Staphylococcus aureus, } \\
\text { Enterococcus faecalis, } \\
\text { Bacillus cereus, } \\
\text { Escherichia coli, } \\
\text { Pseudomonas aeruginosa, } \\
\text { and } \\
\text { Salmonella typhimurium }\end{array}$ & Gentamicin $=0.2-1.56 \mu \mathrm{g} / \mathrm{mL}$ & $\begin{array}{l}\text { Noteworthy effect against } \\
\text { Enterococcus faecalis } \\
(\mathrm{MIC}=80 \mu \mathrm{g} / \mathrm{mL})\end{array}$ & Dzoyem et al., [67] \\
\hline $\begin{array}{l}\text { \# Euphorbia cupularis Boiss. } \\
\text { Synadenium cuplare) }\end{array}$ & Stem/leaves & Hexane & $\begin{array}{l}\text { Serial } \\
\text { microplate } \\
\text { dilution }\end{array}$ & $\begin{array}{l}\text { Escherichia coli, } \\
\text { Enterococcus faecalis, } \\
\text { Pseudomonas aeruginosa, } \\
\text { and Staphylococcus aureus }\end{array}$ & Neomycin $(0.78-25 \mu \mathrm{M})$ & $\begin{array}{l}\text { Hexane extract showed a } \\
\text { weak inhibition against } \\
\text { two Gram- positive }\end{array}$ & McGaw et al., [70] \\
\hline
\end{tabular}


Table 3. Cont

\begin{tabular}{|c|c|c|c|c|c|c|c|}
\hline \# Plant Species & Plant Part & Solvent & Test System & Test Organism & Positive Control & Findings & Reference \\
\hline $\begin{array}{l}\text { \# Heteromorpha arborescens } \\
\text { (Spreng.) Cham. } \\
\text { \& Schltdl. }\end{array}$ & Leaves & Acetone & $\begin{array}{l}\text { Serial } \\
\text { microplate } \\
\text { dilution }\end{array}$ & Bacillus anthracis & Gentamicin $=0.0002 \mathrm{mg} / \mathrm{mL}$ & $\mathrm{MIC}=0.16 \mathrm{mg} / \mathrm{mL}$ & Elisha et al., [66] \\
\hline $\begin{array}{l}\text { Heteromorpha trifoliata } \\
\text { (H.L.Wendl.) Eckl. } \\
\text { \& Zeyh }\end{array}$ & Leaves & Acetone & $\begin{array}{l}\text { Serial } \\
\text { microplate } \\
\text { dilution }\end{array}$ & $\begin{array}{l}\text { Escherichia coli, } \\
\text { Enterococcus faecalis, } \\
\text { Pseudomonas aeruginosa, } \\
\text { and Staphylococcus aureus }\end{array}$ & Gentamicin $\leq 0.02 \mathrm{mg} / \mathrm{mL}$ & $\begin{array}{l}\text { Moderate antibacterial } \\
\text { activity with MIC }=0.63 \\
\text { against two } \\
\text { Gram-negative bacteria }\end{array}$ & Adamu et al., [68] \\
\hline $\begin{array}{l}\text { Indigofera frutescens L.f. } \\
\text { (Syn: Indigofera cylindrica } \\
\text { DC.) }\end{array}$ & Leaves & Acetone & $\begin{array}{l}\text { Serial } \\
\text { microplate } \\
\text { dilution }\end{array}$ & $\begin{array}{l}\text { Escherichia coli, } \\
\text { Enterococcus faecalis, } \\
\text { Pseudomonas aeruginosa, } \\
\text { and Staphylococcus aureus }\end{array}$ & Gentamicin $\leq 0.02 \mathrm{mg} / \mathrm{mL}$ & $\begin{array}{l}\text { Noteworthy antibacterial } \\
\text { effect } \\
(\mathrm{MIC}=0.08-0.31 \mathrm{mg} / \mathrm{mL}) \\
\text { against the four } \\
\text { bacterial strains }\end{array}$ & Adamu et al., [68] \\
\hline $\begin{array}{l}\text { Leucosidea sericea Eckl. } \\
\text { \& Zeyh. }\end{array}$ & Leaves & Acetone & $\begin{array}{l}\text { Serial } \\
\text { microplate } \\
\text { dilution }\end{array}$ & $\begin{array}{l}\text { Escherichia coli, } \\
\text { Enterococcus faecalis, } \\
\text { Pseudomonas aeruginosa, } \\
\text { and Staphylococcus aureus }\end{array}$ & Gentamicin $\leq 0.02 \mathrm{mg} / \mathrm{mL}$ & $\begin{array}{l}\text { Noteworthy antibacterial } \\
\text { effect } \\
(\mathrm{MIC}=0.02-0.08 \mathrm{mg} / \mathrm{mL}) \\
\text { against the four } \\
\text { bacterial strains }\end{array}$ & Adamu et al., [68] \\
\hline
\end{tabular}


Table 3. Cont

\begin{tabular}{|c|c|c|c|c|c|c|c|}
\hline \# Plant Species & Plant Part & Solvent & Test System & Test Organism & Positive Control & Findings & Reference \\
\hline $\begin{array}{l}\text { Leucosidea sericea Eckl. \& } \\
\text { Zeyh. }\end{array}$ & $\begin{array}{l}\text { Leaves, } \\
\text { stem }\end{array}$ & $\begin{array}{l}\text { Petroleum ether, } \\
\text { dichloromethane, } \\
\text { ethanol, water }\end{array}$ & $\begin{array}{l}\text { Serial } \\
\text { microplate } \\
\text { dilution }\end{array}$ & $\begin{array}{l}\text { Bacillus subtilis, } \\
\text { Staphylococcus aureus, } \\
\text { Escherichia coli, and } \\
\text { Klebsiella pneumonia }\end{array}$ & Neomycin $(0.39-1.56 \mu \mathrm{g} / \mathrm{mL})$ & $\begin{array}{l}\text { Majority of the solvent } \\
\text { extracts from the leaves } \\
\text { had noteworthy } \\
\text { antibacterial effect } \\
\text { (MIC }=0.025-0.78 \mathrm{mg} / \mathrm{mL} \text { ) } \\
\text { against all four bacterial } \\
\text { strains. Stem organic } \\
\text { solvent extracts had } \\
\text { remarkable MIC } \\
(0.39-0.78 \mathrm{mg} / \mathrm{mL} \text { ) against } \\
\text { Gram-positive bacteria }\end{array}$ & [69] \\
\hline $\begin{array}{l}\text { Lonchocarpus nelsii } \\
\text { (Schinz) Heering } \\
\text { \& Grimme }\end{array}$ & Leaves & Acetone & $\begin{array}{l}\text { Serial } \\
\text { microplate } \\
\text { dilution }\end{array}$ & $\begin{array}{l}\text { Staphylococcus aureus, } \\
\text { Enterococcus faecalis, } \\
\text { Bacillus cereus, } \\
\text { Escherichia coli, } \\
\text { Pseudomonas aeruginosa, } \\
\text { and } \\
\text { Salmonella typhimurium }\end{array}$ & Gentamicin $=0.2-1.56 \mu \mathrm{g} / \mathrm{mL}$ & $\begin{array}{l}\text { Noteworthy effect against } \\
\text { Enterococcus faecalis and } \\
\text { Salmonella typhimurium } \\
(\mathrm{MIC}=80 \mu \mathrm{g} / \mathrm{mL})\end{array}$ & Dzoyem et al., [67] \\
\hline Maesa lanceolata Forssk. & Leaves & Acetone & $\begin{array}{l}\text { Serial } \\
\text { microplate } \\
\text { dilution }\end{array}$ & Bacillus anthracis & Gentamicin $=0.0002 \mathrm{mg} / \mathrm{mL}$ & $\mathrm{MIC}=0.02 \mathrm{mg} / \mathrm{mL}$ & Elisha et al., [66] \\
\hline Melia azedarach L. & Leaves & Acetone & $\begin{array}{l}\text { Serial } \\
\text { microplate } \\
\text { dilution }\end{array}$ & $\begin{array}{l}\text { Escherichia coli, } \\
\text { Enterococcus faecalis, } \\
\text { Pseudomonas aeruginosa, } \\
\text { and Staphylococcus aureus }\end{array}$ & Gentamicin $\leq 0.02 \mathrm{mg} / \mathrm{mL}$ & $\begin{array}{l}\text { Noteworthy antibacterial } \\
\text { effect } \\
(\mathrm{MIC}=0.16-0.63 \mathrm{mg} / \mathrm{mL}) \\
\text { against the four } \\
\text { bacterial strains }\end{array}$ & Adamu et al., [68] \\
\hline
\end{tabular}


Table 3. Cont

\begin{tabular}{|c|c|c|c|c|c|c|c|}
\hline \# Plant Species & Plant Part & Solvent & Test System & Test Organism & Positive Control & Findings & Reference \\
\hline $\begin{array}{l}\text { \# Millettia grandis (E.Mey.) } \\
\text { Skeels }\end{array}$ & Leaves & Acetone & $\begin{array}{l}\text { Serial } \\
\text { microplate } \\
\text { dilution }\end{array}$ & $\begin{array}{l}\text { Escherichia coli, } \\
\text { Enterococcus faecalis, } \\
\text { Pseudomonas aeruginosa, } \\
\text { and Staphylococcus aureus }\end{array}$ & Gentamicin $\leq 0.02 \mathrm{mg} / \mathrm{mL}$ & $\begin{array}{l}\text { Moderate antibacterial } \\
\text { activity with } \\
\text { MIC }=0.31 \mathrm{mg} / \mathrm{mL} \\
\text { against four bacteria }\end{array}$ & Adamu et al., [68] \\
\hline Morus mesozygia Stapf & Leaves & Acetone & $\begin{array}{l}\text { Serial } \\
\text { microplate } \\
\text { dilution }\end{array}$ & Bacillus anthracis & Gentamicin $=0.0002 \mathrm{mg} / \mathrm{mL}$ & $\mathrm{MIC}=0.04 \mathrm{mg} / \mathrm{mL}$ & Elisha et al., [66] \\
\hline $\begin{array}{l}\text { Podalyria calyptrata (Retz.) } \\
\text { Willd. }\end{array}$ & Leaves & Acetone & $\begin{array}{l}\text { Serial } \\
\text { microplate } \\
\text { dilution }\end{array}$ & $\begin{array}{l}\text { Staphylococcus aureus, } \\
\text { Enterococcus faecalis, } \\
\text { Bacillus cereus, } \\
\text { Escherichia coli, } \\
\text { Pseudomonas aeruginosa, } \\
\text { and } \\
\text { Salmonella typhimurium }\end{array}$ & Gentamicin $=0.2-1.56 \mu \mathrm{g} / \mathrm{mL}$ & $\begin{array}{l}\text { Noteworthy effect against } \\
\text { Salmonella typhimurium } \\
(\mathrm{MIC}=160 \mu \mathrm{g} / \mathrm{mL})\end{array}$ & Dzoyem et al., [67] \\
\hline $\begin{array}{l}\text { Salix mucronata subsp. } \\
\text { capensis (Thunb.) } \\
\text { Immelman (Salix capensis) }\end{array}$ & Bark & $\begin{array}{l}\text { Acetone, } \\
\text { methanol, and } \\
\text { water }\end{array}$ & Agar plate & $\begin{array}{l}\text { Escherichia coli, } \\
\text { Pseudomonas aeruginosa, } \\
\text { Staphylococcus aureus, } \\
\text { Bacillus cereus, } \\
\text { Bacillus pumilus, } \\
\text { Bacillus subtilis, } \\
\text { Micrococcus kristinae, } \\
\text { Klebsiella pneumonia, } \\
\text { Serratia marcescens, and } \\
\text { Enterobacter cloacae }\end{array}$ & ns & $\begin{array}{l}\text { Acetone and methanol } \\
\text { extracts inhibited both } \\
\text { Gram-positive and } \\
\text { Gram-negative bacteria } \\
\text { ranging from } \\
0.5 \text { to } 5 \mathrm{mg} / \mathrm{mL}\end{array}$ & $\begin{array}{l}\text { Masika and } \\
\text { Afolayan [72] }\end{array}$ \\
\hline
\end{tabular}


Table 3. Cont

\begin{tabular}{|c|c|c|c|c|c|c|c|}
\hline \# Plant Species & Plant Part & Solvent & Test System & Test Organism & Positive Control & Findings & Reference \\
\hline $\begin{array}{l}\text { \# Schotia brachypetala } \\
\text { Sond. }\end{array}$ & $\begin{array}{l}\text { Bark, } \\
\text { leavse }\end{array}$ & $\begin{array}{l}\text { Hexane, methanol, } \\
\text { and water }\end{array}$ & $\begin{array}{l}\text { Serial } \\
\text { microplate } \\
\text { dilution }\end{array}$ & $\begin{array}{l}\text { Escherichia coli, } \\
\text { Enterococcus faecalis, } \\
\text { Pseudomonas aeruginosa, } \\
\text { and Staphylococcus aureus }\end{array}$ & Neomycin $(0.78-25 \mu \mathrm{M})$ & $\begin{array}{l}\text { Bark methanol extract had } \\
\text { noteworthy antibacterial } \\
\text { effect } \\
\text { (MIC }=0.1-0.2 \mathrm{mg} / \mathrm{mL}) \\
\text { against two Gram-positive } \\
\text { bacterial strains. Leaf } \\
\text { methanol extract had } \\
\text { noteworthy antibacterial } \\
\text { effect } \\
\text { (MIC }=0.2-0.4 \mathrm{mg} / \mathrm{mL}) \\
\text { against two Gram-positive } \\
\text { bacterial strains }\end{array}$ & McGaw et al., [70] \\
\hline $\begin{array}{l}\text { \# Sclerocarya birrea } \\
\text { (A. Rich.) Hochst. }\end{array}$ & Leaves & $\begin{array}{l}\text { Hexane, methanol, } \\
\text { and water }\end{array}$ & $\begin{array}{l}\text { Serial } \\
\text { microplate } \\
\text { dilution }\end{array}$ & $\begin{array}{l}\text { Escherichia coli, } \\
\text { Enterococcus faecalis, } \\
\text { Pseudomonas aeruginosa, } \\
\text { and Staphylococcus aureus }\end{array}$ & Neomycin $(0.78-25 \mu \mathrm{M})$ & $\begin{array}{l}\text { Methanol extract had } \\
\text { noteworthy antibacterial } \\
\text { effect } \\
\text { (MIC }=0.1-0.4 \mathrm{mg} / \mathrm{mL}) \\
\text { against two Gram-positive } \\
\text { bacterial strains }\end{array}$ & McGaw et al., [70] \\
\hline $\begin{array}{l}\text { \# Searsia lancea (L.f.) } \\
\text { F.A.Barkley (Rhus lanceas) }\end{array}$ & $\begin{array}{l}\text { Bark, } \\
\text { leaves }\end{array}$ & $\begin{array}{l}\text { Hexane, methanol, } \\
\text { and water }\end{array}$ & $\begin{array}{l}\text { Serial } \\
\text { microplate } \\
\text { dilution }\end{array}$ & $\begin{array}{l}\text { Escherichia coli, } \\
\text { Enterococcus faecalis, } \\
\text { Pseudomonas aeruginosa, } \\
\text { and Staphylococcus aureus }\end{array}$ & Neomycin $(0.78-25 \mu \mathrm{M})$ & $\begin{array}{l}\text { Bark methanol extract had } \\
\text { noteworthy antibacterial } \\
\text { effect (MIC }=0.2 \mathrm{mg} / \mathrm{mL} \text { ) } \\
\text { against two Gram-positive } \\
\text { bacterial strains. Leaf } \\
\text { methanol extract had } \\
\text { noteworthy MIC } \\
(0.2 \mathrm{mg} / \mathrm{mL} \text { ) against } \\
\text { Staphylococcus aureus }\end{array}$ & McGaw et al., [70] \\
\hline $\begin{array}{l}\text { Virgilia divaricata } \\
\text { Adamson }\end{array}$ & Leaves & Acetone & $\begin{array}{l}\text { Serial } \\
\text { microplate } \\
\text { dilution }\end{array}$ & $\begin{array}{l}\text { Staphylococcus aureus, } \\
\text { Enterococcus faecalis, } \\
\text { Bacillus cereus, } \\
\text { Escherichia coli, } \\
\text { Pseudomonas aeruginosa, } \\
\text { and } \\
\text { Salmonella typhimurium }\end{array}$ & Gentamicin $=0.2-1.56 \mu \mathrm{g} / \mathrm{mL}$ & $\begin{array}{l}\text { Noteworthy effect against } \\
\text { Bacillus cereus and } \\
\text { Salmonella typhimurium } \\
(\mathrm{MIC}=80 \mu \mathrm{g} / \mathrm{mL})\end{array}$ & Dzoyem et al., [67] \\
\hline
\end{tabular}


Table 3. Cont.

\begin{tabular}{|c|c|c|c|c|c|c|c|}
\hline \# Plant Species & Plant Part & Solvent & Test System & Test Organism & Positive Control & Findings & Reference \\
\hline $\begin{array}{l}\text { \# Volkameria glabra } \\
\text { (E. Mey.) Mabb. \& } \\
\text { Y. W. Yuan (Syn: } \\
\text { Clerodendrum glabrum) }\end{array}$ & Leaves & Acetone & $\begin{array}{l}\text { Serial } \\
\text { microplate } \\
\text { dilution }\end{array}$ & $\begin{array}{l}\text { Escherichia coli, } \\
\text { Enterococcus faecalis, } \\
\text { Pseudomonas aeruginosa, } \\
\text { and Staphylococcus aureus }\end{array}$ & Gentamicin $\leq 0.02 \mathrm{mg} / \mathrm{mL}$ & $\begin{array}{l}\text { Noteworthy antibacterial } \\
\text { effect } \\
\text { (MIC }=0.31-0.63 \mathrm{mg} / \mathrm{mL}) \\
\text { against two Gram-negative } \\
\text { bacterial strains }\end{array}$ & Adamu et al., [68] \\
\hline Xylia torreana Brenan & Leaves & Acetone & $\begin{array}{l}\text { Serial } \\
\text { microplate } \\
\text { dilution }\end{array}$ & $\begin{array}{l}\text { Staphylococcus aureus, } \\
\text { Enterococcus faecalis, } \\
\text { Bacillus cereus, } \\
\text { Escherichia coli, } \\
\text { Pseudomonas aeruginosa, } \\
\text { and } \\
\text { Salmonella typhimurium }\end{array}$ & Gentamicin $=0.2-1.56 \mu \mathrm{g} / \mathrm{mL}$ & $\begin{array}{l}\text { Noteworthy effect against } \\
\text { Bacillus cereus and } \\
\text { Salmonella typhimurium } \\
(\mathrm{MIC}=160 \mu \mathrm{g} / \mathrm{mL})\end{array}$ & Dzoyem et al., [67] \\
\hline $\begin{array}{l}\text { \# Zanthoxylum capense } \\
\text { (Thunb.) Harv. }\end{array}$ & Leaves & Acetone & $\begin{array}{l}\text { Serial } \\
\text { microplate } \\
\text { dilution }\end{array}$ & $\begin{array}{l}\text { Escherichia coli, } \\
\text { Enterococcus faecalis, } \\
\text { Pseudomonas aeruginosa, } \\
\text { and Staphylococcus aureus }\end{array}$ & Gentamicin $\leq 0.02 \mathrm{mg} / \mathrm{mL}$ & $\begin{array}{l}\text { Noteworthy antibacterial } \\
\text { effect (MIC }=0.31 \mathrm{mg} / \mathrm{mL} \text { ) } \\
\text { against } \\
\text { Enterococcus faecalis and } \\
\text { Pseudomonas aeruginosa }\end{array}$ & Adamu et al., [68] \\
\hline
\end{tabular}




\subsubsection{Anthelmintic Activity}

As highlighted by Aremu et al., [74], evaluating anthelmintic potential is often conducted using (i) developmental and behavioural assays (DBA) and (ii) colorimetric assays (CA). Following treatment and incubation with plant extracts, the assays measure the survival and/or reproductive potential (DBA) or metabolic response using the appropriate marker (CA). A total of 48 woody plants have been tested for their anthelmintic activity, which was mainly (90\%) assessed using DBA (Table 4). However, only $42 \%$ of these woody plants had existing indigenous knowledge related to the management of animal health among local communities in South Africa. Alsophila dregei (Kunze) R.M.Tryon, Leucosidea sericea, and Sclerocarya birrea were identified as the most commonly evaluated woody plants in terms of their anthelmintic effect. Using predefined anthelmintic effect categories [69], the organic solvent extracts of Leucosidea sericea had high (minimum lethal concentration, MLC $=0.26-0.52 \mathrm{mg} / \mathrm{mL}$ ) anthelmintic activity against Caenorhabditis elegans [69]. Likewise, Fouche et al., [75] demonstrated that Maerua angolensis stem extract exerted 65\% inhibition, which was noteworthy among all of the evaluated woody plants. Furthermore, extracts from Heteromorpha trifoliata, Maesa lanceolate, and Leucosidea sericea using an egg hatch assay (e.g., of DBA) exhibited significant anthelmintic activity against Haemonchus contortus and killed 100\% of the parasites when administered at the dosages of $12.50,6.25$, and $3.13 \mathrm{mg} / \mathrm{mL}$ [76]. Fouche et al., [75] investigated the acetone extracts of various woody plants for their anthelmintic activity against Haemonchus contortus, and the stem of Maerua angolensis had a mean inhibition rate of $65 \%$, which was noteworthy compared to the other plants tested and included in the review.

Caenorhabditis elegans (63\%), Haemonchus contortus (35\%), and Trichostrongylus colubriformis $(2 \%)$ have been the widely used organisms for assessing the anthelmintic effects of woody species (Table 4). In recent times, the use of free-living nematodes, particularly, have remained common due to their inherent benefits $[74,77,78]$. Caenorhabditis elegans is regarded as the best representative of a large phylum that contains several parasites [78]. However, the use of Caenorhabditis elegans as a test organism has resulted in limited success in terms of the discovery of valuable new leads $[62,77,79]$. Hence, Caenorhabditis elegans should only serve as a screening tool for the rapid identification of promising plant extracts that will be further subjected to more appropriate test model(s).

The type of solvents used for plant extraction has a critical influence on the anthelmintic effect of woody plants (Table 4). For instance, the ethyl acetate extract of Combretum apiculatum exhibited strong lethality, killing $70-80 \%$ of nematodes (Caenorhabditis elegans) while the water extract had a 10-20\% killing rate at $1 \mathrm{mg} / \mathrm{mL}$ [80]. Furthermore, Searsia lancea hexane extract had higher $(50 \%)$ in vitro anthelmintic activity against Caenorhabditis elegans than the methanol and water extracts did [70]. The in vitro anthelmintic efficacy of several woody plants against Caenorhabditis elegans revealed that ethanol extracts possessed higher anthelmintic activity than water extracts [71].

Contrary to the majority of studies focusing on an single test organism (Table 4), Shai et al., [81] evaluated the anthelmintic activity of Curtisia dentata against parasitic (Trichostrongylus colubriformis and Haemonchus contortus) and the free-living (Caenorhabditis elegans) nematodes. The acetone and dichloromethane extracts were active against all of the nematodes at concentrations as low as $160 \mu \mathrm{g} / \mathrm{mL}$. This finding clearly highlights the anthelmintic potential of Curtisia dentata, which requires further experiments, especially in terms of its in vivo response. 


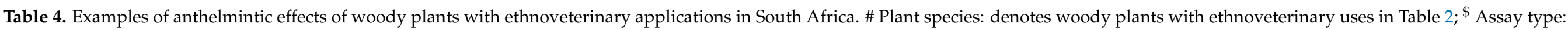
CA—colourimetric assay, DBA—developmental and behavioral assay; ${ }^{*}$ Findings: EHA—egg hatch assay; LDT—larval development test; MLC—minimum lethal concentration.

\begin{tabular}{|c|c|c|c|c|c|c|c|}
\hline \# Plant Species & Solvent & \$ Assay Type & Plant-Part & Parasite & Positive Control & ${ }^{*}$ Findings & Reference \\
\hline $\begin{array}{l}\text { \# Acokanthera oppositifolia } \\
\text { (Lam.) Codd }\end{array}$ & $\begin{array}{l}\text { Petroleum ether, } \\
\text { dichloromethane, } \\
\text { ethanol, and water }\end{array}$ & CA & Leaves, twigs & Caenorhabditis elegans & $\begin{array}{l}\text { Levamisole } \\
(40 \mu \mathrm{g} / \mathrm{mL})\end{array}$ & $\begin{array}{l}\text { Petroleum ether and ethanol } \\
\text { leaf extracts had noteworthy } \\
\text { MLC }(0.52 \mathrm{mg} / \mathrm{mL})\end{array}$ & Aremu et al., [71] \\
\hline $\begin{array}{l}\text { Alsophila dregei (Kunze) } \\
\text { R.M.Tryon } \\
\text { (Cyathea dregei) }\end{array}$ & $\begin{array}{l}\text { Petroleum ether, } \\
\text { dichloromethane, } \\
\text { ethanol, and water }\end{array}$ & CA & Leaves, roots & Caenorhabditis elegans & $\begin{array}{l}\text { Levamisole } \\
(40 \mu \mathrm{g} / \mathrm{mL})\end{array}$ & $\begin{array}{l}\text { Dichloromethane and ethanol } \\
\text { leaf extracts had noteworthy } \\
\text { MLC }(0.52 \mathrm{mg} / \mathrm{mL})\end{array}$ & Aremu et al., [71] \\
\hline $\begin{array}{l}\text { Alsophila dregei (Kunze) } \\
\text { R.M.Tryon } \\
\text { (Cyathea dregei) }\end{array}$ & Acetone & DBA & Leaves & Haemonchus contortus & $\begin{array}{l}\text { Albendazole } \\
(0.008-25 \mu \mathrm{g} / \mathrm{mL})\end{array}$ & $\begin{array}{l}\mathrm{EC}_{50}=17.64 \mathrm{mg} / \mathrm{mL}(\mathrm{EHA}) \\
17.93 \mathrm{mg} / \mathrm{mL}(\mathrm{LDT})\end{array}$ & Adamu et al., [76] \\
\hline $\begin{array}{l}\text { Alsophila dregei (Kunze) } \\
\text { R.M.Tryon } \\
\text { (Cyathea dregei) }\end{array}$ & $\begin{array}{l}\text { Petroleum ether, } \\
\text { dichloromethane, } \\
\text { ethanol, and water }\end{array}$ & CA & Leaves, roots & Caenorhabditis elegans & $\begin{array}{l}\text { Levamisole } \\
(40 \mu \mathrm{g} / \mathrm{mL})\end{array}$ & $\begin{array}{l}\text { Dichloromethane and ethanol } \\
\text { extracts had noteworthy MLC } \\
(0.52 \mathrm{mg} / \mathrm{mL})\end{array}$ & Aremu et al., [71] \\
\hline Apodytes dimidiata & Acetone & DBA & Leaves & Haemonchus contortus & $\begin{array}{l}\text { Albendazole } \\
(0.008-25 \mu \mathrm{g} / \mathrm{mL})\end{array}$ & $\begin{array}{l}\mathrm{EC}_{50}=5.7 \mathrm{mg} / \mathrm{mL}(\mathrm{EHA}) \\
4.13 \mathrm{mg} / \mathrm{mL}(\mathrm{LDT})\end{array}$ & Adamu et al., [76] \\
\hline Berchemia zeyheri & $\begin{array}{l}\text { Hexane, methanol, } \\
\text { and water }\end{array}$ & DBA & Bark & Caenorhabditis elegans & $\begin{array}{l}\text { Levamisole } \\
(10 \mu \mathrm{g} / \mathrm{mL})\end{array}$ & $\begin{array}{l}\text { Methanol extract had } \\
\text { moderate }(30 \%) \text { lethality at } \\
2 \mathrm{mg} / \mathrm{mL}\end{array}$ & McGaw et al., [70] \\
\hline Brachylaena discolor & Acetone & DBA & Leaves & Haemonchus contortus & $\begin{array}{l}\text { Albendazole } \\
(0.008-25 \mu \mathrm{g} / \mathrm{mL})\end{array}$ & $\begin{array}{l}\mathrm{EC}_{50}=3.55 \mathrm{mg} / \mathrm{mL}(\mathrm{EHA}) \\
17.23 \mathrm{mg} / \mathrm{mL}(\mathrm{LDT})\end{array}$ & Adamu et al., [76] \\
\hline \# Calpurnia aurea & Acetone & DBA & $\begin{array}{l}\text { Leaves/flowers, } \\
\text { stem }\end{array}$ & Haemonchus contortus & $\begin{array}{l}\text { Albendazole }(100 \% \\
\text { at } 0.008-25 \mu \mathrm{g} / \mathrm{mL})\end{array}$ & $\begin{array}{l}\text { EHA inhibition }=27 \% \\
\text { (leaves } / \text { flowers), } 32 \% \text { (stem) }\end{array}$ & Fouche et al., [75] \\
\hline Clausena anisata & Acetone & DBA & Leaves & Haemonchus contortus & $\begin{array}{l}\text { Albendazole } \\
(0.008-25 \mu \mathrm{g} / \mathrm{mL})\end{array}$ & $\begin{array}{l}\mathrm{EC}_{50}=1.8 \mathrm{mg} / \mathrm{mL}(\mathrm{EHA}) \\
2.07 \mathrm{mg} / \mathrm{mL}(\mathrm{LDT})\end{array}$ & Adamu et al., [76] \\
\hline $\begin{array}{l}\text { Combretum apiculatum } \\
\text { Sond. Subsp. Apiculatum }\end{array}$ & $\begin{array}{l}\text { Ethyl acetate, } \\
\text { acetone, and water }\end{array}$ & DBA & Leaves & Caenorhabditis elegans & Levamisole & $\begin{array}{l}\text { Ethyl acetate extract had } \\
70-80 \% \text { lethality at } 1 \mathrm{mg} / \mathrm{mL}\end{array}$ & McGaw et al., [80] \\
\hline $\begin{array}{l}\text { Combretum bracteosum } \\
\text { (Hochst.) Engl. \& Diels }\end{array}$ & $\begin{array}{l}\text { Ethyl acetate, } \\
\text { acetone, and water }\end{array}$ & DBA & Leaves & Caenorhabditis elegans & Levamisole & No activity observed & McGaw et al., [80] \\
\hline
\end{tabular}


Table 4. Cont.

\begin{tabular}{|c|c|c|c|c|c|c|c|}
\hline \# Plant Species & Solvent & \$ Assay Type & Plant-Part & Parasite & Positive Control & * Findings & Reference \\
\hline $\begin{array}{l}\text { Combretum celastroides } \\
\text { Welw ex Laws subsp. } \\
\text { Celastroides }\end{array}$ & $\begin{array}{l}\text { Ethyl acetate, } \\
\text { acetone, and water }\end{array}$ & DBA & Leaves & Caenorhabditis elegans & Levamisole & No activity observed & McGaw et al., [80] \\
\hline $\begin{array}{l}\text { Combretum collinum } \\
\text { Fresen }\end{array}$ & $\begin{array}{l}\text { Ethyl acetate, } \\
\text { acetone, and water }\end{array}$ & DBA & Leaves & Caenorhabditis elegans & Levamisole & $\begin{array}{l}\text { Acetone extract had } \\
10-20 \% \text { lethality at } \\
0.5 \text { and } 1 \mathrm{mg} / \mathrm{mL}\end{array}$ & McGaw et al., [80] \\
\hline $\begin{array}{l}\text { Combretum edwardsii } \\
\text { Exell }\end{array}$ & $\begin{array}{l}\text { Ethyl acetate, } \\
\text { acetone, and water }\end{array}$ & DBA & Leaves & Caenorhabditis elegans & Levamisole & $\begin{array}{l}\text { Acetone and ethyl acetate } \\
\text { extracts had } 10-20 \% \text { lethality } \\
\text { at } 1 \mathrm{mg} / \mathrm{mL}\end{array}$ & McGaw et al., [80] \\
\hline $\begin{array}{l}\text { Combretum } \\
\text { erythrophyllum (Burch.) } \\
\text { Sond. }\end{array}$ & $\begin{array}{l}\text { Ethyl acetate, } \\
\text { acetone, and water }\end{array}$ & DBA & Leaves & Caenorhabditis elegans & Levamisole & $\begin{array}{l}\text { Acetone and ethyl acetate } \\
\text { extracts had } 10-20 \% \text { lethality } \\
\text { at } 1 \mathrm{mg} / \mathrm{mL}\end{array}$ & McGaw et al., [80] \\
\hline $\begin{array}{l}\text { Combretum hereroense } \\
\text { Schinz }\end{array}$ & $\begin{array}{l}\text { Ethyl acetate, } \\
\text { acetone, and water }\end{array}$ & DBA & Leaves & Caenorhabditis elegans & Levamisole & $\begin{array}{l}\text { Acetone extract had } \\
20-30 \% \text { lethality at } 1 \mathrm{mg} / \mathrm{mL}\end{array}$ & McGaw et al., [80] \\
\hline $\begin{array}{l}\text { Combretum imberbe } \\
\text { Wawra }\end{array}$ & $\begin{array}{l}\text { Ethyl acetate, } \\
\text { acetone, and water }\end{array}$ & DBA & Leaves & Caenorhabditis elegans & Levamisole & $\begin{array}{l}\text { Acetone extract had } \\
20-30 \% \text { lethality at } 1 \mathrm{mg} / \mathrm{mL}\end{array}$ & McGaw et al., [80] \\
\hline $\begin{array}{l}\text { \# Combretum } \\
\text { microphyllum }\end{array}$ & $\begin{array}{l}\text { Ethyl acetate, } \\
\text { acetone, and water }\end{array}$ & DBA & Leaves & Caenorhabditis elegans & Levamisole & $\begin{array}{l}\text { Acetone and ethyl acetate } \\
\text { extracts had } 10-20 \% \text { lethality } \\
\text { at } 0.5 \text { and } 1 \mathrm{mg} / \mathrm{mL}\end{array}$ & McGaw et al., [80] \\
\hline $\begin{array}{l}\text { Combretum mkuzense } \\
\text { J.D.Carr \& Retief }\end{array}$ & $\begin{array}{l}\text { Ethyl acetate, } \\
\text { acetone, and water }\end{array}$ & DBA & Leaves & Caenorhabditis elegans & Levamisole & $\begin{array}{l}\text { Acetone extract had } \\
20-30 \% \text { lethality at } 1 \mathrm{mg} / \mathrm{mL}\end{array}$ & McGaw et al., [80] \\
\hline Combretum moggi Exell & $\begin{array}{l}\text { Ethyl acetate, } \\
\text { acetone, and water }\end{array}$ & DBA & Leaves & Caenorhabditis elegans & Levamisole & No activity observed & McGaw et al., [80] \\
\hline
\end{tabular}


Table 4. Cont.

\begin{tabular}{|c|c|c|c|c|c|c|c|}
\hline \# Plant Species & Solvent & \$ Assay Type & Plant-Part & Parasite & Positive Control & * Findings & Reference \\
\hline $\begin{array}{l}\text { \# Combretum molle R.Br. } \\
\text { ex. G.Don }\end{array}$ & $\begin{array}{l}\text { Ethyl acetate, } \\
\text { acetone, and water }\end{array}$ & DBA & Leaves & Caenorhabditis elegans & Levamisole & $\begin{array}{l}\text { Acetone extract had } \\
20-30 \% \text { lethality at } 1 \mathrm{mg} / \mathrm{mL}\end{array}$ & McGaw et al., [80] \\
\hline $\begin{array}{l}\text { Combretum mossambicense } \\
\text { (Klotzsch) Engl. }\end{array}$ & $\begin{array}{l}\text { Ethyl acetate, } \\
\text { acetone, and water }\end{array}$ & DBA & Leaves & Caenorhabditis elegans & Levamisole & $\begin{array}{l}\text { Acetone extract had } \\
20-30 \% \text { lethality at } 1 \mathrm{mg} / \mathrm{mL}\end{array}$ & McGaw et al., [80] \\
\hline Combretum padoides Engl. & $\begin{array}{l}\text { Ethyl acetate, } \\
\text { acetone, and water }\end{array}$ & DBA & Leaves & Caenorhabditis elegans & Levamisole & No activity observed & McGaw et al., [80] \\
\hline $\begin{array}{l}\text { \# Combretum paniculatum } \\
\text { Vent. }\end{array}$ & $\begin{array}{l}\text { Ethyl acetate, } \\
\text { acetone, and water }\end{array}$ & DBA & Leaves & Caenorhabditis elegans & Levamisole & $\begin{array}{l}\text { Acetone extract had } \\
10-20 \% \text { lethality at } \\
0.5 \mathrm{mg} / \mathrm{mL}\end{array}$ & McGaw et al., [80] \\
\hline $\begin{array}{l}\text { Combretum petrophilum } \\
\text { Retief }\end{array}$ & $\begin{array}{l}\text { Ethyl acetate, } \\
\text { acetone, and water }\end{array}$ & DBA & Leaves & Caenorhabditis elegans & Levamisole & $\begin{array}{l}\text { Acetone extract had } \\
10-20 \% \text { lethality at } \\
0.5 \mathrm{mg} / \mathrm{mL}\end{array}$ & McGaw et al., [80] \\
\hline Combretum woodii & $\begin{array}{l}\text { Ethyl acetate, } \\
\text { acetone, and water }\end{array}$ & DBA & Leaves & Caenorhabditis elegans & Levamisole & No activity observed & McGaw et al., [80] \\
\hline Combretum zeyheri & $\begin{array}{l}\text { Ethyl acetate, } \\
\text { acetone, and water }\end{array}$ & DBA & Leaves & Caenorhabditis elegans & Levamisole & No activity observed & McGaw et al., [80] \\
\hline \# Curtisia dentata & $\begin{array}{l}\text { Dichloromethane } \\
\text { and acetone }\end{array}$ & DBA & Leaves & $\begin{array}{l}\text { Caenorhabditis elegans, } \\
\text { Haemonchus contortus, } \\
\text { Trichostrongylus colubriformis }\end{array}$ & $\begin{array}{l}\text { Levamisole } \\
(10 \mu \mathrm{g} / \mathrm{mL})\end{array}$ & $\begin{array}{l}\text { Acetone extracts had the } \\
\text { highest inhibition at } \\
2.5 \mathrm{mg} / \mathrm{mL} \text { after } 2 \mathrm{~h} \text { and } \\
7 \text { days of incubation. Both } \\
\text { extracts inhibited the highest } \\
\text { motility at } 1.25-2.5 \\
\text { (Haemonchus contortus) and } \\
0.63-2.5 \mathrm{mg} / \mathrm{mL} \\
\text { (Trichostrongylus colubriformis) }\end{array}$ & Shai et al., [81] \\
\hline \# Cussonia spicata & $\begin{array}{l}\text { Hexane, methanol, } \\
\text { and water }\end{array}$ & DBA & Roots & Caenorhabditis elegans & $\begin{array}{l}\text { Levamisole } \\
(10 \mu \mathrm{g} / \mathrm{mL})\end{array}$ & No noteworthy activity & McGaw et al., [70] \\
\hline
\end{tabular}


Table 4. Cont.

\begin{tabular}{|c|c|c|c|c|c|c|c|}
\hline \# Plant Species & Solvent & \$ Assay Type & Plant-Part & Parasite & Positive Control & ${ }^{*}$ Findings & Reference \\
\hline \# Dombeya rotundifolia & $\begin{array}{l}\text { Hexane, methanol, } \\
\text { and water }\end{array}$ & DBA & Aerial parts & Caenorhabditis elegans & $\begin{array}{l}\text { Levamisole } \\
(10 \mu \mathrm{g} / \mathrm{mL})\end{array}$ & $\begin{array}{l}\text { Water extract had } 20 \% \\
\text { lethality at } 1 \text { and } 2 \mathrm{mg} / \mathrm{mL}\end{array}$ & McGaw et al., [70] \\
\hline $\begin{array}{l}\text { \# Euphorbia cupularis } \\
\text { (Syn: } \\
\text { Synadenium cupulare } \\
\text { (Boiss.) }\end{array}$ & $\begin{array}{l}\text { Hexane, methanol, } \\
\text { and water }\end{array}$ & DBA & Stem/leaves & Caenorhabditis elegans & $\begin{array}{l}\text { Levamisole } \\
(10 \mu \mathrm{g} / \mathrm{mL})\end{array}$ & No noteworthy activity & McGaw et al., [70] \\
\hline Ficus sycomorus & Acetone & DBA & $\begin{array}{l}\text { Bark/stem, } \\
\text { stem }\end{array}$ & Haemonchus contortus & $\begin{array}{l}\text { Albendazole }(100 \% \\
\text { at } 0.008-25 \mu \mathrm{g} / \mathrm{mL})\end{array}$ & $\begin{array}{l}\text { EHA inhibition }=25 \% \\
(\text { bark } / \text { stem), } 21 \%(\text { stem })\end{array}$ & Fouche et al., [75] \\
\hline Heteromorpha trifoliata & Acetone & DBA & Leaves & Haemonchus contortus & $\begin{array}{l}\text { Albendazole } \\
(0.008-25 \mu \mathrm{g} / \mathrm{mL})\end{array}$ & $\begin{array}{l}\mathrm{EC}_{50}=0.62 \mathrm{mg} / \mathrm{mL}(\mathrm{EHA}) \\
0.64 \mathrm{mg} / \mathrm{mL}(\mathrm{LDT})\end{array}$ & Adamu et al., [76] \\
\hline \# Hippobromus pauciflorus & $\begin{array}{l}\text { Hexane, methanol, } \\
\text { and water }\end{array}$ & DBA & Aerial parts & Caenorhabditis elegans & $\begin{array}{l}\text { Levamisole } \\
(10 \mu \mathrm{g} / \mathrm{mL})\end{array}$ & $\begin{array}{l}\text { Hexane extract had } 50 \% \\
\text { lethality at } 2 \mathrm{mg} / \mathrm{mL}\end{array}$ & McGaw et al., [70] \\
\hline Indigofera frutescens & Acetone & DBA & Leaves & Haemonchus contortus & $\begin{array}{l}\text { Albendazole } \\
(0.008-25 \mu \mathrm{g} / \mathrm{mL})\end{array}$ & $\begin{array}{l}\mathrm{EC}_{50}=7.11 \mathrm{mg} / \mathrm{mL}(\mathrm{EHA}) \\
7.58 \mathrm{mg} / \mathrm{mL}(\mathrm{LDT})\end{array}$ & Adamu et al., [76] \\
\hline Leucosidea sericea & Acetone & DBA & Leaves & Haemonchus contortus & $\begin{array}{l}\text { Albendazole } \\
(0.008-25 \mu \mathrm{g} / \mathrm{mL})\end{array}$ & $\begin{array}{l}\mathrm{EC}_{50}=1.08 \mathrm{mg} / \mathrm{mL}(\mathrm{EHA}) \\
1.27 \mathrm{mg} / \mathrm{mL}(\mathrm{LDT})\end{array}$ & Adamu et al., [76] \\
\hline Leucosidea sericea & $\begin{array}{l}\text { Petroleum ether, } \\
\text { dichloromethane, } \\
\text { ethanol, and water }\end{array}$ & CA & Leaves, stem & Caenorhabditis elegans & $\begin{array}{l}\text { Levamisole } \\
(40 \mu \mathrm{g} / \mathrm{mL})\end{array}$ & $\begin{array}{l}\text { Petroleum ether, } \\
\text { dichloromethane, and ethanol } \\
\text { leaf extracts had noteworthy } \\
\text { anthelmintic effect } \\
(\mathrm{MLC}=0.26-0.52 \mathrm{mg} / \mathrm{mL})\end{array}$ & Aremu et al., [69] \\
\hline \# Maerua angolensis & Acetone & DBA & Stem, leaves & Haemonchus contortus & $\begin{array}{l}\text { Albendazole }(100 \% \\
\text { at } 0.008-25 \mu \mathrm{g} / \mathrm{mL})\end{array}$ & $\begin{array}{l}\text { EHA inhibition }=65 \% \text { (stem), } \\
25 \% \text { (leaves) }\end{array}$ & Fouche et al., [75] \\
\hline Maesa lanceolata & Acetone & DBA & Leaves & Haemonchus contortus & $\begin{array}{l}\text { Albendazole } \\
(0.008-25 \mu \mathrm{g} / \mathrm{mL})\end{array}$ & $\begin{array}{l}\mathrm{EC}_{50}=0.72 \mathrm{mg} / \mathrm{mL}(\mathrm{EHA}) \\
1.68 \mathrm{mg} / \mathrm{mL}(\mathrm{LDT})\end{array}$ & Adamu et al., [76] \\
\hline Melia azedarach & Acetone & DBA & Leaves & Haemonchus contortus & $\begin{array}{l}\text { Albendazole } \\
(0.008-25 \mu \mathrm{g} / \mathrm{mL})\end{array}$ & $\begin{array}{l}\mathrm{EC}_{50}=6.24 \mathrm{mg} / \mathrm{mL}(\mathrm{EHA}) \\
10.96 \mathrm{mg} / \mathrm{mL}(\mathrm{LDT})\end{array}$ & Adamu et al., [76] \\
\hline \# Milletia grandis & Acetone & DBA & Leaves & Haemonchus contortus & $\begin{array}{l}\text { Albendazole } \\
(0.008-25 \mu \mathrm{g} / \mathrm{m})\end{array}$ & $\begin{array}{l}\mathrm{EC}_{50}=5.57 \mathrm{mg} / \mathrm{mL}(\mathrm{EHA}) \\
6.11 \mathrm{mg} / \mathrm{mL}(\mathrm{LDT})\end{array}$ & Adamu et al., [76] \\
\hline
\end{tabular}


Table 4. Cont.

\begin{tabular}{|c|c|c|c|c|c|c|c|}
\hline \# Plant Species & Solvent & \$ Assay Type & Plant-Part & Parasite & Positive Control & ${ }^{*}$ Findings & Reference \\
\hline $\begin{array}{l}\text { \# Schotia brachypetala } \\
\text { Sond }\end{array}$ & $\begin{array}{l}\text { Hexane, methanol, } \\
\text { and water }\end{array}$ & DBA & Leaves, bark & Caenorhabditis elegans & $\begin{array}{l}\text { Levamisole } \\
(10 \mu \mathrm{g} / \mathrm{mL})\end{array}$ & $\begin{array}{l}\text { All solvent extracts from, } \\
\text { bark had } 10 \% \text { at } 2 \mathrm{mg} / \mathrm{mL} \text {. } \\
\text { Hexane extract from leaves } \\
\text { had } 10 \% \text { lethality at } 2 \mathrm{mg} / \mathrm{mL}\end{array}$ & McGaw et al., [70] \\
\hline \# Sclerocarya birrea & Acetone & DBA & Fruit & Haemonchus contortus & $\begin{array}{l}\text { Albendazole }(100 \% \\
\text { at } 0.008-25 \mu \mathrm{g} / \mathrm{mL})\end{array}$ & EHA inhibition $=28 \%$ & Fouche et al., [75] \\
\hline \# Sclerocarya birrea & $\begin{array}{l}\text { Hexane, methanol, } \\
\text { and water }\end{array}$ & DBA & Bark & Caenorhabditis elegans & $\begin{array}{l}\text { Levamisole } \\
(10 \mu \mathrm{g} / \mathrm{mL})\end{array}$ & $\begin{array}{l}\text { Methanol extract had } \\
40 \% \text { lethality at } 2 \mathrm{mg} / \mathrm{mL}\end{array}$ & McGaw et al., [70] \\
\hline $\begin{array}{l}\text { \# Searsia lancea (Syn: } \\
\text { Rhus lancea) }\end{array}$ & $\begin{array}{l}\text { Hexane, methanol, } \\
\text { and water }\end{array}$ & DBA & Leaves, bark & Caenorhabditis elegans & $\begin{array}{l}\text { Levamisole } \\
(10 \mu \mathrm{g} / \mathrm{mL})\end{array}$ & $\begin{array}{l}\text { Hexane extracts had } 50 \% \\
\text { (leaves) and } 40 \% \text { (bark) } \\
\text { lethality at } 2 \mathrm{mg} / \mathrm{mL}\end{array}$ & McGaw et al., [70] \\
\hline \# Senna petersiana & $\begin{array}{l}\text { Petroleum ether, } \\
\text { dichloromethane, } \\
\text { ethanol, and water }\end{array}$ & CA & Leaves & Caenorhabditis elegans & $\begin{array}{l}\text { Levamisole } \\
(40 \mu \mathrm{g} / \mathrm{mL})\end{array}$ & Ethanol extract $=0.52 \mathrm{mg} / \mathrm{mL}$ & Aremu et al., [71] \\
\hline Strychnos mitis & Acetone & DBA & Leaves & Haemonchus contortus & $\begin{array}{l}\text { Albendazole } \\
(0.008-25 \mu \mathrm{g} / \mathrm{mL})\end{array}$ & $\begin{array}{l}\mathrm{EC}_{50}=16.56 \mathrm{mg} / \mathrm{mL}(\mathrm{EHA}) \\
16.94 \mathrm{mg} / \mathrm{mL}(\mathrm{LDT})\end{array}$ & Adamu et al., [76] \\
\hline $\begin{array}{l}\text { \# Volkameria glabra } \\
\text { (Clerodendrum glabrum) }\end{array}$ & Acetone & DBA & Leaves & Haemonchus contortus & $\begin{array}{l}\text { Albendazole } \\
(0.008-25 \mu \mathrm{g} / \mathrm{mL})\end{array}$ & $\begin{array}{l}\mathrm{EC}_{50}=1.48 \mathrm{mg} / \mathrm{mL}(\mathrm{EHA}) \\
12.97 \mathrm{mg} / \mathrm{mL}(\mathrm{LDT})\end{array}$ & Adamu et al., [76] \\
\hline \# Zanthoxylum capense & Acetone & DBA & Leaves & Haemonchus contortus & $\begin{array}{l}\text { Albendazole } \\
(0.008-25 \mu \mathrm{g} / \mathrm{mL})\end{array}$ & $\begin{array}{l}\mathrm{EC}_{50}=13.26 \mathrm{mg} / \mathrm{mL}(\mathrm{EHA}) \\
13.64 \mathrm{mg} / \mathrm{mL}(\mathrm{LDT})\end{array}$ & Adamu et al., [76] \\
\hline \# Ziziphus mucronata & $\begin{array}{l}\text { Hexane, methanol, } \\
\text { and water }\end{array}$ & DBA & Bark, leaves & Caenorhabditis elegans & $\begin{array}{l}\text { Levamisole } \\
(10 \mu \mathrm{g} / \mathrm{mL})\end{array}$ & No noteworthy activity & McGaw et al., [70] \\
\hline
\end{tabular}




\subsubsection{Antioxidant Activity}

Antioxidants are free radical scavengers and often possess the ability to reverse or repair the damage caused by free radicals in animal cells [82]. Recently, there has been increasing interest in determining the antioxidant potential of plants used for medicinal purposes [83]. It is generally known that damages caused by reactive oxygen species are often a contributing factor to many diseases [84]. As shown in Table 5, the antioxidant potential of the 24 woody plants have mainly been evaluated via in vitro assays including ABTS-2,2' azinobis-(3-ethylbenzothiazoline-6-sulfonic acid), DPPH-1,1-diphenyl-2-picryl-hydrazyl, and FRAP -ferric reducing antioxidant power. Relative to the inventory in Table 2, only six woody plants show antioxidant activity.

Given that these bio-analytical assays differ in terms of reaction mechanisms, oxidant, and target species as well as reaction conditions [82], it is often beneficial to evaluate plant extracts in multi-assays. Based on the DPPH assay, the most promising $\left(\mathrm{EC}_{50}<5 \mu \mathrm{g} / \mathrm{mL}\right)$ antioxidant activity was exerted by woody plants such as Alsophila dregei, Apodytes dimidiata, Brachylaena discolor, Burkea africana, Clausena anisata, Combretanum zeyheri, Millettia grandis, Strychnos mitis, Volkameria glabra, and Zanthoxylum capense. Similar noteworthy antixodant effects was observed in the ABTS assay for Burkea africana and Combretum zeyheri [85]. However, moderate antioxidant activity ranging from $68-579 \mu \mathrm{g} / \mathrm{mL}$ was demonstrated among the eight evaluated woody plants. These aforementioned antioxidant tests were in vitro-based, thereby limiting the clinical relevance of the current findings. Hence, it will be pertinent to establish the in vivo antioxidant activity of woody plants with noteworthy response.

Table 5. Examples of in vitro antioxidant effect of woody plants used for ethnoveterinary medicine in South Africa. \# Plant species: denotes woody plants with ethnoveterinary uses in Table 2. ABTS-2,2'-azinobis-(3-ethylbenzothiazoline-6sulfonic acid), DPPH-1,1-diphenyl-2-picryl-hydrazyl, FRAP—ferric reducing antioxidant power, TEAC—trolox equivalent antioxidant assay.

\begin{tabular}{|c|c|c|c|c|}
\hline \# Plant Species & Assay Type & Plant Part & Findings & Reference \\
\hline $\begin{array}{l}\text { Alsophila dregei (Kunze) R.M.Tryon (Syn: } \\
\text { Cyathea dregei) }\end{array}$ & DPPH & Leaves & $\mathrm{EC}_{50}=3 \mu \mathrm{g} / \mathrm{mL}$ & Adamu et al., [68] \\
\hline $\begin{array}{l}\text { Alsophila dregei (Kunze) R.M.Tryon (Syn: } \\
\text { Cyathea dregei) }\end{array}$ & ABTS & Leaves & 0.4 TEAC & Adamu et al., [68] \\
\hline Apodytes dimidiata E.Mey. ex. Arn. & $\mathrm{DPPH}$ & Leaves & $\mathrm{EC}_{50}=3.5 \mu \mathrm{g} / \mathrm{mL}$ & Adamu et al., [68] \\
\hline Apodytes dimidiata E.Mey. ex. Arn. & ABTS & Leaves & 0.3 TEAC & Adamu et al., [68] \\
\hline Brachylaena discolor DC. & DPPH & Leaves & $\mathrm{EC}_{50}=2.6 \mu \mathrm{g} / \mathrm{mL}$ & Adamu et al., [68] \\
\hline Brachylaena discolor DC. & ABTS & Leaves & 0.2 TEAC & Adamu et al., [68] \\
\hline Burkea africana Hook. & $\mathrm{DPPH}$ & Leaves & $\mathrm{IC}_{50}=3.55 \mu \mathrm{g} / \mathrm{mL}$ & Dzoyem and Eloff [85] \\
\hline Burkea africana Hook. & ABTS & Leaves & $\mathrm{IC}_{50}=3.21 \mu \mathrm{g} / \mathrm{mL}$ & Dzoyem and Eloff [85] \\
\hline Burkea africana Hook. & FRAP & Leaves & $\mathrm{IC}_{50}=231.07 \mu \mathrm{g} \mathrm{Fe}(\mathrm{II}) / \mathrm{g}$ & Dzoyem and Eloff [85] \\
\hline Clausena anisata (Willd.) Hook.f. ex. Benth. & $\mathrm{DPPH}$ & Leaves & $\mathrm{EC}_{50}=2.5 \mu \mathrm{g} / \mathrm{mL}$ & Adamu et al., [68] \\
\hline Clausena anisata (Willd.) Hook.f. ex. Benth. & ABTS & Leaves & 0.2 TEAC & Adamu et al., [68] \\
\hline Combretum zeyheri Sond. & $\mathrm{DPPH}$ & Leaves & $\mathrm{IC}_{50}=3.52 \mu \mathrm{g} / \mathrm{mL}$ & Dzoyem and Eloff [85] \\
\hline Combretum zeyheri Sond. & ABTS & Leaves & $\mathrm{IC}_{50}=4.64 \mu \mathrm{g} / \mathrm{mL}$ & Dzoyem and Eloff [85] \\
\hline Combretum zeyheri Sond. & FRAP & Leaves & $\mathrm{IC}_{50}=95.98 \mu \mathrm{g} \mathrm{Fe}(\mathrm{II}) / \mathrm{g}$ & Dzoyem and Eloff [85] \\
\hline Dalbergia nitidula Welw. ex. Baker & DPPH & Leaves & $\mathrm{IC}_{50}=9.31 \mu \mathrm{g} / \mathrm{mL}$ & Dzoyem et al., [67] \\
\hline Dalbergia nitidula Welw. ex. Baker & ABTS & Leaves & $\mathrm{IC}_{50}=21.3 \mu \mathrm{g} / \mathrm{mL}$ & Dzoyem et al., [67] \\
\hline $\begin{array}{l}\text { \# Englerophytum magalismontanum (Sond.) } \\
\text { T.D.Penn }\end{array}$ & DPPH & Leaves & $\mathrm{IC}_{50}=10.8 \mu \mathrm{g} / \mathrm{mL}$ & Dzoyem and Eloff [85] \\
\hline $\begin{array}{l}\text { \# Englerophytum magalismontanum (Sond.) } \\
\text { T.D.Penn }\end{array}$ & ABTS & Leaves & $\mathrm{IC}_{50}=12.22 \mu \mathrm{g} / \mathrm{mL}$ & Dzoyem and Eloff [85] \\
\hline
\end{tabular}


Table 5. Cont.

\begin{tabular}{|c|c|c|c|c|}
\hline \# Plant Species & Assay Type & Plant Part & Findings & Reference \\
\hline $\begin{array}{l}\text { \# Englerophytum magalismontanum (Sond.) } \\
\text { T.D.Penn }\end{array}$ & FRAP & Leaves & $\mathrm{IC}_{50}=76 \mu \mathrm{g} \mathrm{Fe}(\mathrm{II}) / \mathrm{g}$ & Dzoyem and Eloff [85] \\
\hline \# Erythrina caffra Thunb. & DPPH & Leaves & $\mathrm{IC}_{50}=268.6 \mu \mathrm{g} / \mathrm{mL}$ & Dzoyem et al., [67] \\
\hline \# Erythrina caffra Thunb. & ABTS & Leaves & $\mathrm{IC}_{50}=173.28 \mu \mathrm{g} / \mathrm{mL}$ & Dzoyem et al., [67] \\
\hline Euclea undulata Thunb. & $\mathrm{DPPH}$ & Leaves & $31.66 \mu \mathrm{g} / \mathrm{mL}$ & Dzoyem and Eloff [85] \\
\hline Euclea undulata Thunb. & ABTS & Leaves & $32.67 \mu \mathrm{g} / \mathrm{mL}$ & Dzoyem and Eloff [85] \\
\hline Euclea undulata Thunb. & FRAP & Leaves & $274.19 \mu \mathrm{g} \mathrm{Fe}(\mathrm{II}) / \mathrm{g}$ & Dzoyem and Eloff [85] \\
\hline $\begin{array}{l}\text { Heteromorpha trifoliata (H.L.Wendl.) } \\
\text { Eckl. \& Zeyh. }\end{array}$ & $\mathrm{DPPH}$ & Leaves & $\mathrm{EC}_{50}=4.36 \mu \mathrm{g} / \mathrm{mL}$ & Adamu et al., [68] \\
\hline $\begin{array}{l}\text { Heteromorpha trifoliata (H.L.Wendl.) } \\
\text { Eckl. \& Zeyh. }\end{array}$ & ABTS & Leaves & $0.2 \mathrm{TEAC}$ & Adamu et al., [68] \\
\hline Indigofera frutescens L.f. & $\mathrm{DPPH}$ & Leaves & $\mathrm{EC}_{50}=0 \mu \mathrm{g} / \mathrm{mL}$ & Adamu et al., [68] \\
\hline Indigofera frutescens L.f. & ABTS & Leaves & 0.5 TEAC & Adamu et al., [68] \\
\hline Indigofera frutescens L.f. & $\mathrm{DPPH}$ & Leaves & $\mathrm{IC}_{50}=22.31 \mu \mathrm{g} / \mathrm{mL}$ & Dzoyem et al., [67] \\
\hline Indigofera frutescens L.f. & ABTS & Leaves & $\mathrm{IC}_{50}=134.64 \mu \mathrm{g} / \mathrm{mL}$ & Dzoyem et al., [67] \\
\hline \# Jatropha curcas L. & $\mathrm{DPPH}$ & Leaves & $\mathrm{IC}_{50}=137.08 \mu \mathrm{g} / \mathrm{mL}$ & Dzoyem and Eloff [85] \\
\hline \# Jatropha curcas L. & ABTS & Leaves & $\mathrm{IC}_{50}=115.23 \mu \mathrm{g} / \mathrm{mL}$ & Dzoyem and Eloff [85] \\
\hline \# Jatropha curcas L. & FRAP & Leaves & $\mathrm{IC}_{50}=68.17 \mu \mathrm{g} \mathrm{Fe}(\mathrm{II}) / \mathrm{g}$ & Dzoyem and Eloff [85] \\
\hline Leucaena leucocephala (Lam.) de Wit & $\mathrm{DPPH}$ & Leaves & $\mathrm{IC}_{50}=9.86 \mu \mathrm{g} / \mathrm{mL}$ & Dzoyem and Eloff [85] \\
\hline Leucaena leucocephala (Lam.) de Wit & ABTS & Leaves & $\mathrm{IC}_{50}=9.85 \mu \mathrm{g} / \mathrm{mL}$ & Dzoyem and Eloff [85] \\
\hline Leucaena leucocephala (Lam.) de Wit & FRAP & Leaves & $\mathrm{IC}_{50}=289.27 \mu \mathrm{g} \mathrm{Fe}(\mathrm{II}) / \mathrm{g}$ & Dzoyem and Eloff [85] \\
\hline Leucosidea sericea & $\mathrm{DPPH}$ & Leaves & $\mathrm{EC}_{50}=0.0 \mu \mathrm{g} / \mathrm{mL}$ & Adamu et al., [68] \\
\hline Leucosidea sericea & ABTS & Leaves & 0.7 TEAC & Adamu et al., [68] \\
\hline Maesa lanceolata Forssk. & $\mathrm{DPPH}$ & Leaves & $\mathrm{EC}_{50}=1.4 \mu \mathrm{g} / \mathrm{mL}$ & Adamu et al., [68] \\
\hline Maesa lanceolata Forssk. & ABTS & Leaves & 1.2 TEAC & Adamu et al., [68] \\
\hline Melia azedarach $\mathrm{L}$. & $\mathrm{DPPH}$ & Leaves & $\mathrm{EC}_{50}=3.3 \mu \mathrm{g} / \mathrm{mL}$ & Adamu et al., [68] \\
\hline Melia azedarach $\mathrm{L}$. & ABTS & Leaves & $0.8 \mathrm{TEAC}$ & Adamu et al., [68] \\
\hline \# Millettia grandis (E.Mey.) Skeels & $\mathrm{DPPH}$ & Leaves & $\mathrm{EC}_{50}=4.6 \mu \mathrm{g} / \mathrm{mL}$ & Adamu et al., [68] \\
\hline \# Millettia grandis (E.Mey.) Skeels & ABTS & Leaves & $0.6 \mathrm{TEAC}$ & Adamu et al., [68] \\
\hline Morus mesozygia Stapf & $\mathrm{DPPH}$ & Leaves & $\mathrm{IC}_{50}=15.85 \mu \mathrm{g} / \mathrm{mL}$ & Dzoyem and Eloff [85] \\
\hline Morus mesozygia Stapf & ABTS & Leaves & $\mathrm{IC}_{50}=271.86 \mu \mathrm{g} / \mathrm{mL}$ & Dzoyem and Eloff [85] \\
\hline Morus mesozygia Stapf & FRAP & Leaves & $\mathrm{IC}_{50}=127.34 \mu \mathrm{g} \mathrm{Fe}(\mathrm{II}) / \mathrm{g}$ & Dzoyem and Eloff [85] \\
\hline $\begin{array}{l}\text { Philenoptera nelsii (Schinz) Schrire } \\
\text { (Lonchocarpus nelsii) }\end{array}$ & $\mathrm{DPPH}$ & Leaves & $\mathrm{IC}_{50}=247.7 \mu \mathrm{g} / \mathrm{mL}$ & Adamu et al., [68] \\
\hline $\begin{array}{l}\text { Philenoptera nelsii (Schinz) Schrire } \\
\text { (Lonchocarpus nelsii) }\end{array}$ & ABTS & Leaves & $\mathrm{IC}_{50}=41.39 \mu \mathrm{g} / \mathrm{mL}$ & Adamu et al., [68] \\
\hline Strychnos mitis S.Moore & $\mathrm{DPPH}$ & Leaves & $\mathrm{EC}_{50}=3.5 \mu \mathrm{g} / \mathrm{mL}$ & Adamu et al., [68] \\
\hline Strychnos mitis S.Moore & ABTS & Leaves & 0.3 TEAC & Adamu et al., [68] \\
\hline Uapaca nitida Müll.Arg. & $\mathrm{DPPH}$ & Leaves & $\mathrm{IC}_{50}=125.86 \mu \mathrm{g} / \mathrm{mL}$ & Dzoyem and Eloff [85] \\
\hline Uapaca nitida Müll.Arg. & ABTS & Leaves & $\mathrm{IC}_{50}=28.81 \mu \mathrm{g} / \mathrm{mL}$ & Dzoyem and Eloff [85] \\
\hline Uapaca nitida Müll.Arg. & FRAP & Leaves & $\mathrm{IC}_{50}=177.32 \mu \mathrm{g} \mathrm{Fe}(\mathrm{II}) / \mathrm{g}$ & Dzoyem and Eloff [85] \\
\hline
\end{tabular}


Table 5. Cont.

\begin{tabular}{|c|c|c|c|c|}
\hline \# Plant Species & Assay Type & Plant Part & Findings & Reference \\
\hline $\begin{array}{l}\text { \# Volkameria glabra (E. Mey.) Mabb. \& Y. W. } \\
\text { Yuan (Syn: Clerodendrum glabrum) }\end{array}$ & DPPH & Leaves & $\mathrm{EC}_{50}=3.5 \mu \mathrm{g} / \mathrm{mL}$ & Adamu et al., [68] \\
\hline $\begin{array}{l}\text { \# Volkameria glabra (E. Mey.) Mabb. \& Y. W. } \\
\text { Yuan (Syn: Clerodendrum glabrum) }\end{array}$ & ABTS & Leaves & 0.5 TEAC & Adamu et al., [68] \\
\hline \# Zanthoxylum capense (Thunb.) Harv. & DPPH & Leaves & $\mathrm{EC}_{50}=4 \mu \mathrm{g} / \mathrm{mL}$ & Adamu et al., [68] \\
\hline \# Zanthoxylum capense (Thunb.) Harv. & ABTS & Leaves & 0.4 TEAC & Adamu et al., [68] \\
\hline
\end{tabular}

\subsubsection{Cytotoxicity}

The safety of medicinal plants remains essential toward the drive to incorporate these valuable natural resources as part of healthcare for animals. Evidence of the cytotoxicity levels for 39 woody plants were recorded in the current review (Table 6). Approximately $51 \%$ of these woody plants have explicit applications in South African ethnoveterinary medicine (Table 2). Particularly, the safety of different organs from three plants namely Calpurnia aurea, Maesa lanceolata, and Sclerocarya birrea were assessed in more than one study $[66,70,75,76]$.

According to the United States National Cancer Institute (NCI), the criteria for the cytotoxicity of crude extracts, extracts with an $\mathrm{LC}_{50}$ value that is less than $20 \mu \mathrm{g} / \mathrm{mL}$ are classified as cytotoxic. On this basis, Apodytes dimidiate, Brachylaena discolour, Calpurnia aurea, Elaeodendron croceum, Maesa lanceolata, and Strychnos mitis exerted varying degrees of cytotoxicity $\left(\mathrm{LC}_{50}=3.32-19.9 \mu \mathrm{g} / \mathrm{mL}\right.$ ), and caution needs to be taken during their utilisation for ethnoveterinary medicine $[66,67,76]$. Furthermore, McGaw et al., [70] assessed the cytotoxicity activity of the hexane, methanol, and water extracts of the selected woody plants against the larvae of Artemia salina (brine shrimp). From the results, the water extracts from Searsia lancea and Ziziphus mucronata leaves displayed strong lethality to the tested organism. On the other hand, moderate cytotoxicity was demonstrated by the acetone and water extracts of Vachellia nilotica bark against Vero monkey cell assays, and these extracts exhibited toxic effects on the cells with $\mathrm{LC}_{50}=33.2 \mu \mathrm{g} / \mathrm{mL}$ and $\mathrm{LC}_{50}=27.8 \mu \mathrm{g} / \mathrm{mL}$, respectively. This was closely-followed by the acetone extracts from Tetradenia riparia, leaf with $\mathrm{LC}_{50}=51.3 \mu \mathrm{g} / \mathrm{mL}[86]$.

\subsection{Phytochemical Analysis of Plants Used for Ethnoveterinary Purposes}

Phytochemical screening is important when investigating medicinal plants given that bioactive compounds can be responsible for their resultant biological activities [87,88]. In particular, the phenolic compounds in plants serve as defense mechanisms against pathogens and may be explored for therapeutic purposes [89]. The 20 woody plants recorded exhibit a diverse range of phytochemicals (Table 7), an indication of their potential benefits as ethnoveterinary medicine. For instance, 12 selected woody plant extracts had a rich source of phenols that ranged from 100 to $428 \mathrm{mg} \mathrm{GAE} / \mathrm{g}$, and Lippia javanica had the highest phenolic content while Englerophytum magaliesmontanum had the lowest content [85]. In addition, the flavonoid content varied from 6-159 mg QE/g, as contained in Ehretia rigida (lowest) and Leucaena leucocephala (highest). Olaokun et al., [90] quantified the total phenolic and flavonoid contents in Curtisia dentata and Pittosporum viridiflorum. The results indicated that Curtisia dentata extract yielded the higher phenolics (125.12 mg/g GAE) and flavonoids (27.69 mg/g GAE) compared to the extract from Pittosporum viridiflorum. 


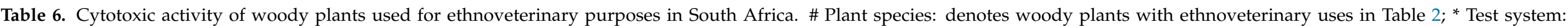
MTT-3-5-dimethyl thiazol-2-yl-2, 5-diphenyl tetrazolium bromide.

\begin{tabular}{|c|c|c|c|c|c|c|}
\hline \# Plant Species & Solvent & Plant Part & * Test System & Positive Control & Findings & Reference \\
\hline $\begin{array}{l}\text { Alsophila dregei (Syn: } \\
\text { Cyathea dregei) }\end{array}$ & Acetone & Leaves & $\begin{array}{l}\text { Tetrazolium-based colorimetric MTT } \\
\text { assay using Vero monkey kidney cells }\end{array}$ & Berberine chloride & $\mathrm{LC}_{50}=0.00332 \mathrm{mg} / \mathrm{mL}$ & Adamu et al., [76] \\
\hline Apodytes dimidiata & Acetone & Leaves & $\begin{array}{l}\text { Tetrazolium-based colorimetric MTT } \\
\text { assay using Vero monkey kidney cells }\end{array}$ & Berberine chloride & $\mathrm{LC}_{50}=0.00396 \mathrm{mg} / \mathrm{mL}$ & Adamu et al., [76] \\
\hline Berchemia zeyheri & $\begin{array}{l}\text { Hexane, methanol, } \\
\text { and water }\end{array}$ & Bark & $\begin{array}{l}\text { Brine shrimp lethality/toxicity using } \\
\text { Artemia salina }\end{array}$ & Podophyllotoxin $(7 \mu \mathrm{g} / \mathrm{mL})$ & $\begin{array}{l}\text { Water extract had the } \\
\text { highest lethal effect } \\
\left(\mathrm{LC}_{50}=3.9 \mathrm{mg} / \mathrm{mL}\right)\end{array}$ & McGaw et al., [70] \\
\hline Brachylaena discolor & Acetone & Leaves & $\begin{array}{l}\text { Tetrazolium-based colorimetric MTT } \\
\text { assay using Vero monkey kidney cells }\end{array}$ & Berberine chloride & $\mathrm{LC}_{50}=0.00752 \mathrm{mg} / \mathrm{mL}$ & Adamu et al., [76] \\
\hline \# Calpurnia aurea & Acetone & Leaves & $\begin{array}{l}\text { Tetrazolium-based colorimetric MTT } \\
\text { assay using Vero monkey kidney cells }\end{array}$ & Doxorubicin $=1.76 \mu \mathrm{g} / \mathrm{mL}$ & $\mathrm{LC}_{50}=13.6 \mu \mathrm{g} / \mathrm{mL}$ & Elisha et al., [66] \\
\hline \# Calpurnia aurea & Acetone & $\begin{array}{l}\text { Leaves/flowers, } \\
\text { stem }\end{array}$ & $\begin{array}{l}\text { Tetrazolium-based colorimetric MTT } \\
\text { assay using Vero monkey kidney cells }\end{array}$ & Doxorubicin $(2.97 \mu \mathrm{g} / \mathrm{mL})$ & $\begin{array}{l}\text { Leaves } / \text { flowers, } \\
\mathrm{LC}_{50}=166.63 \mu \mathrm{g} / \mathrm{mL} \text {, } \\
\text { Stem } \\
\mathrm{LC}_{50}=223.97 \mu \mathrm{g} / \mathrm{mL}\end{array}$ & Fouche et al., [75] \\
\hline Clausena anisata & Acetone & Leaves & $\begin{array}{l}\text { Tetrazolium-based colorimetric MTT } \\
\text { assay using Vero monkey kidney cells }\end{array}$ & Berberine chloride & $\mathrm{LC}_{50}=0.17186 \mathrm{mg} / \mathrm{mL}$ & Adamu et al., [76] \\
\hline Cremaspora triflora & Acetone & Leaves & $\begin{array}{l}\text { Tetrazolium-based colorimetric MTT } \\
\text { assay using Vero monkey kidney cells }\end{array}$ & Doxorubicin $=1.76 \mu \mathrm{g} / \mathrm{mL}$ & $\mathrm{LC}_{50}=57.4 \mu \mathrm{g} / \mathrm{mL}$ & Elisha et al., [66] \\
\hline \# Cussonia spicata & $\begin{array}{l}\text { Hexane, methanol, } \\
\text { and water }\end{array}$ & Roots & $\begin{array}{l}\text { Brine shrimp lethality/toxicity using } \\
\text { Artemia salina }\end{array}$ & Podophyllotoxin $(7 \mu \mathrm{g} / \mathrm{mL})$ & $\begin{array}{l}\text { Water extract had the } \\
\text { highest lethal effect } \\
\left(\mathrm{LC}_{50}=2.6 \mathrm{mg} / \mathrm{mL}\right)\end{array}$ & McGaw et al., [70] \\
\hline Dalbergia nitidula & Acetone & Leaves & $\begin{array}{l}\text { Tetrazolium-based colorimetric MTT } \\
\text { assay using Vero monkey kidney cells }\end{array}$ & Doxorubicin $(2.29 \mu \mathrm{g} / \mathrm{mL})$ & $\mathrm{LC}_{50}=51.28 \mu \mathrm{g} / \mathrm{mL}$ & Dzoyem et al., [67] \\
\hline \# Dombeya rotundifolia & $\begin{array}{l}\text { Hexane, methanol, } \\
\text { and water }\end{array}$ & Aerial part & $\begin{array}{l}\text { Brine shrimp lethality/toxicity using } \\
\text { Artemia salina }\end{array}$ & Podophyllotoxin $(7 \mu \mathrm{g} / \mathrm{mL})$ & $\begin{array}{l}\text { All extracts had no } \\
\text { lethal effect }\end{array}$ & McGaw et al., [70] \\
\hline $\begin{array}{l}\text { Elaeodendron croceum } \\
\text { (Thunb.) DC. }\end{array}$ & Acetone & Leaves & $\begin{array}{l}\text { Tetrazolium-based colorimetric MTT } \\
\text { assay using Vero monkey kidney cells }\end{array}$ & Doxorubicin $=1.76 \mu \mathrm{g} / \mathrm{mL}$ & $\mathrm{LC}_{50}=5.2 \mu \mathrm{g} / \mathrm{mL}$ & Elisha et al., [66] \\
\hline
\end{tabular}


Table 6. Cont.

\begin{tabular}{|c|c|c|c|c|c|c|}
\hline \# Plant Species & Solvent & Plant Part & * Test System & Positive Control & Findings & Reference \\
\hline \# Erythrina caffra & Acetone & Leaves & $\begin{array}{l}\text { Tetrazolium-based colorimetric MTT } \\
\text { assay using Vero monkey kidney cells }\end{array}$ & Doxorubicin $(2.29 \mu \mathrm{g} / \mathrm{mL})$ & $\mathrm{LC}_{50}=19.93 \mu \mathrm{g} / \mathrm{mL}$ & Dzoyem et al., [67] \\
\hline $\begin{array}{l}\text { \# Euphorbia cupularis (Syn: } \\
\text { Synadenium cupulare) }\end{array}$ & $\begin{array}{l}\text { Hexane, methanol, } \\
\text { and water }\end{array}$ & Aerial part & $\begin{array}{l}\text { Brine shrimp lethality/toxicity using } \\
\text { Artemia salina }\end{array}$ & Podophyllotoxin $(7 \mu \mathrm{g} / \mathrm{mL})$ & $\begin{array}{l}\text { All extracts had no } \\
\text { lethal effect }\end{array}$ & McGaw et al., [70] \\
\hline Ficus sycomorus & Acetone & $\begin{array}{l}\text { Bark/stem, } \\
\text { stem }\end{array}$ & $\begin{array}{l}\text { Tetrazolium-based colorimetric MTT } \\
\text { assay using Vero monkey kidney cells }\end{array}$ & Doxorubicin $(2.97 \mu \mathrm{g} / \mathrm{mL})$ & $\begin{array}{l}\mathrm{LC}_{50}=172.94 \mu \mathrm{g} / \mathrm{mL} \\
(\text { bark } / \text { stem) } \\
\mathrm{LC}_{50}=48.74 \mu \mathrm{g} / \mathrm{mL} \\
(\text { stem) }\end{array}$ & Fouche et al., [75] \\
\hline \# Heteromorpha arborescens & Acetone & Leaves & $\begin{array}{l}\text { Tetrazolium-based colorimetric MTT } \\
\text { assay using Vero monkey kidney cells }\end{array}$ & Doxorubicin $=1.76 \mu \mathrm{g} / \mathrm{mL}$ & $\mathrm{LC}_{50}=81.0 \mu \mathrm{g} / \mathrm{mL}$ & Elisha et al., [66] \\
\hline Heteromorpha trifoliata & Acetone & Leaves & $\begin{array}{l}\text { Tetrazolium-based colorimetric MTT } \\
\text { assay using Vero monkey kidney cells }\end{array}$ & Berberine chloride & $\mathrm{LC}_{50}=0.04252 \mathrm{mg} / \mathrm{mL}$ & Adamu et al., [76] \\
\hline \# Hippobromus pauciflorus & $\begin{array}{l}\text { Hexane, methanol, } \\
\text { and water }\end{array}$ & Aerial part & $\begin{array}{l}\text { Brine shrimp lethality/toxicity using } \\
\text { Artemia salina }\end{array}$ & Podophyllotoxin $(7 \mu \mathrm{g} / \mathrm{mL})$ & $\begin{array}{l}\text { All extract had no } \\
\text { lethal effect }\end{array}$ & McGaw et al., [70] \\
\hline Indigofera cylindrica & Acetone & Leaves & $\begin{array}{l}\text { Tetrazolium-based colorimetric MTT } \\
\text { assay using Vero monkey kidney cells }\end{array}$ & Doxorubicin $(2.29 \mu \mathrm{g} / \mathrm{mL})$ & $\mathrm{LC}_{50}=77.59 \mu \mathrm{g} / \mathrm{mL}$ & Dzoyem et al., [67] \\
\hline Indigofera frutescens & Acetone & Leaves & $\begin{array}{l}\text { Tetrazolium-based colorimetric MTT } \\
\text { assay using Vero monkey kidney cells }\end{array}$ & Berberine chloride & $\mathrm{LC}_{50}=0.1044 \mathrm{mg} / \mathrm{mL}$ & Adamu et al., [76] \\
\hline Leucosidea sericea & Acetone & Leaves & $\begin{array}{l}\text { Tetrazolium-based colorimetric MTT } \\
\text { assay using Vero monkey kidney cells }\end{array}$ & Berberine chloride & $\mathrm{LC}_{50}=0.0515 \mathrm{mg} / \mathrm{mL}$ & Adamu et al., [76] \\
\hline Lonchocarpus nelsii & Acetone & Leaves & $\begin{array}{l}\text { Tetrazolium-based colorimetric MTT } \\
\text { assay using Vero monkey kidney cells }\end{array}$ & Doxorubicin $(2.29 \mu \mathrm{g} / \mathrm{mL})$ & $\mathrm{LC}_{50}=81.09 \mu \mathrm{g} / \mathrm{mL}$ & Dzoyem et al., [67] \\
\hline \# Maerua angolensis & Acetone & Stem, leaves & $\begin{array}{l}\text { Tetrazolium-based colorimetric MTT } \\
\text { assay using Vero monkey kidney cells }\end{array}$ & Doxorubicin $(2.97 \mu \mathrm{g} / \mathrm{mL})$ & $\begin{array}{l}\mathrm{LC}_{50}=180.64 \mu \mathrm{g} / \mathrm{mL} \\
(\text { stem) } \\
\mathrm{LC}_{50}=73.76 \mu \mathrm{g} / \mathrm{mL} \\
\text { (leaves) }\end{array}$ & Fouche et al., [75] \\
\hline Maesa lanceolata & Acetone & Leaves & $\begin{array}{l}\text { Tetrazolium-based colorimetric MTT } \\
\text { assay using Vero monkey kidney cells }\end{array}$ & Berberine chloride & $\mathrm{LC}_{50}=0.01577 \mathrm{mg} / \mathrm{mL}$ & Adamu et al., [76] \\
\hline Maesa lanceolata & Acetone & Leaves & $\begin{array}{l}\text { Tetrazolium-based colorimetric MTT } \\
\text { assay using Vero monkey kidney cells }\end{array}$ & Doxorubicin $=1.76 \mu \mathrm{g} / \mathrm{mL}$ & $\mathrm{LC}_{50}=0.38 \mu \mathrm{g} / \mathrm{mL}$ & Elisha et al., [66] \\
\hline
\end{tabular}


Table 6. Cont.

\begin{tabular}{|c|c|c|c|c|c|c|}
\hline \# Plant Species & Solvent & Plant Part & * Test System & Positive Control & Findings & Reference \\
\hline Melia azedarach & Acetone & Leaves & $\begin{array}{l}\text { Tetrazolium-based colorimetric MTT } \\
\text { assay using Vero monkey kidney cells }\end{array}$ & Berberine chloride & $\mathrm{LC}_{50}=0.14466 \mathrm{mg} / \mathrm{mL}$ & Adamu et al., [76] \\
\hline \# Milletia grandis & Acetone & Leaves & $\begin{array}{l}\text { Tetrazolium-based colorimetric MTT } \\
\text { assay using Vero monkey kidney cells }\end{array}$ & Berberine chloride & $\mathrm{LC}_{50}=0.05336 \mathrm{mg} / \mathrm{mL}$ & Adamu et al., [76] \\
\hline Morus mesozygia & Acetone & Leaves & $\begin{array}{l}\text { Tetrazolium-based colorimetric MTT } \\
\text { assay using Vero monkey kidney cells }\end{array}$ & Doxorubicin $=1.76 \mu \mathrm{g} / \mathrm{mL}$ & $\mathrm{LC}_{50}=40.7 \mu \mathrm{g} / \mathrm{mL}$ & Elisha et al., [66] \\
\hline \# Pittosporum viridiflorum & Acetone & Leaves & $\begin{array}{l}\text { Tetrazolium-based colorimetric MTT } \\
\text { assay using Vero monkey kidney cells }\end{array}$ & Doxorubicin $=1.76 \mu \mathrm{g} / \mathrm{mL}$ & $\mathrm{LC}_{50}=54.6 \mu \mathrm{g} / \mathrm{mL}$ & Elisha et al., [66] \\
\hline \# Pterocarpus angolensis & $\begin{array}{l}\text { Hexane, methanol, } \\
\text { and water }\end{array}$ & Bark, leaves & $\begin{array}{l}\text { Brine shrimp lethality/toxicity using } \\
\text { Artemia salina }\end{array}$ & Podophyllotoxin $(7 \mu \mathrm{g} / \mathrm{mL})$ & $\begin{array}{l}\text { All extracts from the } \\
\text { bark had no lethal effect. } \\
\text { Hexane and methanol } \\
\text { extracts from the leaves } \\
\text { had the highest } \\
\text { lethal effect } \\
\left(\mathrm{LC}_{50}=3.6-3.8 \mathrm{mg} / \mathrm{mL}\right)\end{array}$ & McGaw et al., [70] \\
\hline \# Sclerocarya birrea & Acetone & Fruit & $\begin{array}{l}\text { Tetrazolium-based colorimetric MTT } \\
\text { assay using Vero monkey kidney cells }\end{array}$ & Doxorubicin $(2.97 \mu \mathrm{g} / \mathrm{mL})$ & $\mathrm{LC}_{50}=214.79 \mu \mathrm{g} / \mathrm{mL}$ & Fouche et al., [75] \\
\hline \# Sclerocarya birrea & $\begin{array}{l}\text { Hexane, methanol, } \\
\text { and water }\end{array}$ & Bark & $\begin{array}{l}\text { Brine shrimp lethality/toxicity using } \\
\text { Artemia salina }\end{array}$ & Podophyllotoxin $(7 \mu \mathrm{g} / \mathrm{mL})$ & $\begin{array}{l}\text { All extracts had no } \\
\text { lethal effect }\end{array}$ & McGaw et al., [70] \\
\hline $\begin{array}{l}\text { \# Searsia lancea } \\
\text { (Rhus lancea) }\end{array}$ & $\begin{array}{l}\text { Hexane, methanol, } \\
\text { and water }\end{array}$ & Bark, leaves & $\begin{array}{l}\text { Brine shrimp lethality/toxicity using } \\
\text { Artemia salina }\end{array}$ & Podophyllotoxin $(7 \mu \mathrm{g} / \mathrm{mL})$ & $\begin{array}{l}\text { Water extract from the } \\
\text { bark }\left(\mathrm{LC}_{50}=3.9 \mathrm{mg} / \mathrm{mL}\right) \\
\text { and leaves } \\
\left(\mathrm{LC}_{50}=0.6 \mathrm{mg} / \mathrm{mL}\right) \text { had } \\
\text { the highest toxic effect }\end{array}$ & McGaw et al., [70] \\
\hline Strychnos mitis & Acetone & Leaves & $\begin{array}{l}\text { Tetrazolium-based colorimetric MTT } \\
\text { assay using Vero monkey kidney cells }\end{array}$ & Berberine chloride & $\mathrm{LC}_{50}=0.01721 \mathrm{mg} / \mathrm{mL}$ & Adamu et al., [76] \\
\hline \# Tabernaemontana elegans & Acetone & Leaves & $\begin{array}{l}\text { Tetrazolium-based colorimetric MTT } \\
\text { assay using Vero monkey kidney cells }\end{array}$ & Doxorubicin $(2.97 \mu \mathrm{g} / \mathrm{mL})$ & $\mathrm{LC}_{50}=32.35 \mu \mathrm{g} / \mathrm{mL}$ & Fouche et al., [75] \\
\hline
\end{tabular}


Table 6. Cont

\begin{tabular}{|c|c|c|c|c|c|c|}
\hline \# Plant Species & Solvent & Plant Part & * Test System & Positive Control & Findings & Reference \\
\hline \# Tetradenia riparia & $\begin{array}{l}\text { Acetone and } \\
\text { water }\end{array}$ & $\begin{array}{l}\text { Flowers, } \\
\text { leaves }\end{array}$ & $\begin{array}{l}\text { Tetrazolium-based colorimetric MTT } \\
\text { assay using Vero monkey kidney cells }\end{array}$ & Doxorubicin $(5.4326 \mu \mathrm{M})$ & $\begin{array}{l}\mathrm{LC}_{50}, \\
\text { flowers }=0.0823 \mathrm{mg} / \mathrm{mL} \\
\text { (acetone), } 0.1784 \mathrm{mg} / \mathrm{mL} \\
\text { (water); } \\
\text { leaves }=0.0513 \mathrm{mg} / \mathrm{mL} \\
\text { (acetone), } 0.2738 \mathrm{mg} / \mathrm{mL} \\
\text { (water) }\end{array}$ & Sserunkuma et al., [86] \\
\hline $\begin{array}{l}\text { \# Vachellia nilotica } \\
\text { (Acacia nilotica) }\end{array}$ & $\begin{array}{l}\text { Acetone and } \\
\text { water }\end{array}$ & Bark, leaves & $\begin{array}{l}\text { Tetrazolium-based colorimetric MTT } \\
\text { assay using Vero monkey kidney cells }\end{array}$ & Doxorubicin $(5.4326 \mu \mathrm{M})$ & $\begin{array}{l}\mathrm{LC}_{50}, \\
\text { bark }=0.0332 \mathrm{mg} / \mathrm{mL} \\
\text { (acetone), } 0.0278 \mathrm{mg} / \mathrm{mL} \\
\text { (water); } \\
\text { leaves }=0.2187 \mathrm{mg} / \mathrm{mL} \\
\text { (acetone), } 0.0688 \mathrm{mg} / \mathrm{mL} \\
\text { (water) }\end{array}$ & Sserunkuma et al., [86] \\
\hline Virgilia divaricata Adamson & Acetone & Leaves & $\begin{array}{l}\text { Tetrazolium-based colorimetric MTT } \\
\text { assay using Vero monkey kidney cells }\end{array}$ & Doxorubicin $(2.29 \mu \mathrm{g} / \mathrm{mL})$ & $\mathrm{LC}_{50}=30.08 \mu \mathrm{g} / \mathrm{mL}$ & Dzoyem et al., [67] \\
\hline $\begin{array}{l}\text { \# Volkameria glabra } \\
\text { (Clerodendrum glabrum) }\end{array}$ & Acetone & Leaves & $\begin{array}{l}\text { Tetrazolium-based colorimetric MTT } \\
\text { assay using Vero monkey kidney cells }\end{array}$ & Berberine chloride & $\mathrm{LC}_{50}=0.04251 \mathrm{mg} / \mathrm{mL}$ & Adamu et al., [76] \\
\hline \# Zanthoxylum capense & Acetone & Leaves & $\begin{array}{l}\text { Tetrazolium-based colorimetric MTT } \\
\text { assay using Vero monkey kidney cells }\end{array}$ & Berberine chloride & $\mathrm{LC}_{50}=0.02095 \mathrm{mg} / \mathrm{mL}$ & Adamu et al., [76] \\
\hline \# Ziziphus mucronata & $\begin{array}{l}\text { Hexane, methanol } \\
\text { and water }\end{array}$ & Bark, leaves & $\begin{array}{l}\text { Brine shrimp lethality/toxicity using } \\
\text { Artemia salina }\end{array}$ & Podophyllotoxin $(7 \mu \mathrm{g} / \mathrm{mL})$ & $\begin{array}{l}\text { Bark extracts had no } \\
\text { lethal effect. Hexane } \\
\text { extract of leaves had } \\
\mathrm{LC}_{50}=0.9 \mathrm{mg} / \mathrm{mL}\end{array}$ & McGaw et al., [70] \\
\hline
\end{tabular}


Table 7. Phytochemical analysis (based on spectrophotometric method) of woody plants used in ethnoveterinary medicine. \# Plant species: denotes woody plants with ethnoveterinary uses in Table 2; GAE—gallic acid equivalents, TPC—-total phenolic content, TFC — total flavonoid content, CT—condensed tannin, GC—gallotannin content, LCE-leucocyanidin equivalents, CTE—-atechin equivalents, QE-quercetin equivalents.

\begin{tabular}{|c|c|c|c|c|}
\hline \# Plant Species & Plant Part & Extract & Findings & Reference \\
\hline \# Acokanthera oppositifolia & Leaves, twigs & $50 \%$ Methanol & $\begin{array}{l}\mathrm{TPC}=2.5 \text { and } 7.2 \mathrm{mg} \mathrm{GAE} / \mathrm{g} \\
\mathrm{GC}=2 \mu \mathrm{g} \text { and } 5.2 \mu \mathrm{g} \text { GAE } / \mathrm{g} \\
\mathrm{CT}=0.005 \% \text { and } 0.12 \% \mathrm{LCE} / \mathrm{g} \\
\mathrm{TFC}=0.002 \text { and } 0.001 \mathrm{mg} \mathrm{CTE} / \mathrm{g}\end{array}$ & Aremu et al., [71] \\
\hline Burkea africana & Leaves & Acetone & $\mathrm{TPC}=14.39 \mathrm{mg} \mathrm{GAE} / \mathrm{g}$ & Dzoyem and Eloff [85] \\
\hline Combretum zeyheri & Leaves & Acetone & $\mathrm{TPC}=3.29 \mathrm{mg} \mathrm{GAE} / \mathrm{g}$ & Dzoyem and Eloff [85] \\
\hline \# Curtisia dentata & Stem bark & Acetone & $\mathrm{TPC}=8.94 \mathrm{mg} \mathrm{GAE} / \mathrm{g}$ & Olaokun et al., [90] \\
\hline Dalbergia nitidula & Leaves & Acetone & $\mathrm{TPC}=1.51 \mathrm{mg} \mathrm{GAE} / \mathrm{g}$ & Dzoyem et al., [67] \\
\hline $\begin{array}{l}\text { \# Englerophytum } \\
\text { magalismontanum }\end{array}$ & Leaves & Acetone & $\mathrm{TPC}=0.86 \mathrm{mg} \mathrm{GAE} / \mathrm{g}$ & Dzoyem and Eloff [85] \\
\hline \# Erythrina caffra & Leaves & Acetone & $\begin{array}{l}\mathrm{TPC}=150.82 \mathrm{mg} / \mathrm{g} \mathrm{GAE} \\
\mathrm{TFC}=72.8 \mathrm{mg} \mathrm{QE} / \mathrm{g}\end{array}$ & Dzoyem et al., [67] \\
\hline Euclea undulata & Leaves & Acetone & $\begin{array}{l}\mathrm{TPC}=234.56 \mathrm{mg} / \mathrm{g} \mathrm{GAE} \\
\mathrm{TFC}=64.36 \mathrm{mg} \mathrm{QE} / \mathrm{g}\end{array}$ & Dzoyem and Eloff [85] \\
\hline $\begin{array}{l}\text { Indigofera frutescens } \\
\text { (Indigofera cylindrical) }\end{array}$ & Leaves & Acetone & $\begin{array}{l}\mathrm{TPC}=125.12 \mathrm{mg} / \mathrm{g} \mathrm{GAE} \\
\mathrm{TFC}=27.69 \mathrm{mg} / \mathrm{g} \mathrm{QE}\end{array}$ & Dzoyem et al., [67] \\
\hline \# Jatropha curcas & Leaves & Acetone & $\begin{array}{l}\mathrm{TPC}=100.89 \mathrm{mg} / \mathrm{g} \mathrm{GAE} \\
\mathrm{TFC}=68.43 \mathrm{mg} \mathrm{QE} / \mathrm{g}\end{array}$ & Dzoyem and Eloff [85] \\
\hline Leucaena leucocephala & Leaves & Acetone & $\begin{array}{l}\mathrm{TPC}=129.78 \mathrm{mg} / \mathrm{g} \mathrm{GAE} \\
\mathrm{TFC}=35.16 \mathrm{mg} \mathrm{QE} / \mathrm{g}\end{array}$ & Dzoyem and Eloff [85] \\
\hline Leucosidea sericea & Leaves, stem & $50 \%$ Methanol & $\begin{array}{l}\mathrm{TPC}=36.66 \text { and } 6.4 \mathrm{mg} \mathrm{GAE} / \mathrm{g} \\
\mathrm{GC}=29.32 \text { and } 5.12 \mu \mathrm{g} \mathrm{GAE} / \mathrm{g} \\
\mathrm{CT}=0.46 \text { and } 0.47 \% \mathrm{LCE} / \mathrm{g} \\
\mathrm{TFC}=0.66 \text { and } 0.26 \mathrm{mg} \mathrm{CTE} / \mathrm{g}\end{array}$ & Aremu et al., [69] \\
\hline $\begin{array}{l}\text { Lippia javanica (Burm.f) } \\
\text { Spreng }\end{array}$ & Leaves & Acetone & $\mathrm{TPC}=130.12 \mathrm{mg} \mathrm{GAE} / \mathrm{g}$ & Dzoyem and Eloff [85] \\
\hline Morus mesozygia & Leaves & Acetone & $\begin{array}{l}\mathrm{TPC}=427.53 \mathrm{mg} / \mathrm{g} \mathrm{GAE} \\
\mathrm{TFC}=80.72 \mathrm{mg} \mathrm{QE} / \mathrm{g}\end{array}$ & Dzoyem and Eloff [85] \\
\hline $\begin{array}{l}\text { Philenoptera nelsii } \\
\text { (Lonchocarpus nelsii) }\end{array}$ & Leaves & Acetone & $\begin{array}{l}\mathrm{TPC}=258.4 \mathrm{mg} / \mathrm{g} \mathrm{GAE} \\
\mathrm{TFC}=159.61 \mathrm{mg} \mathrm{QE} / \mathrm{g}\end{array}$ & Dzoyem et al., [67] \\
\hline $\begin{array}{l}\text { \# Pittosporum viridiflorum } \\
\text { Sims }\end{array}$ & Stem bark & Acetone & $\begin{array}{l}\mathrm{TPC}=181.49 \mathrm{mg} / \mathrm{g} \mathrm{GAE} \\
\mathrm{TFC}=13.75 \mathrm{mg} \mathrm{QE} / \mathrm{g}\end{array}$ & Olaokun et al., [90] \\
\hline \# Senna petersiana & Leaves & $50 \%$ Methanol & $\begin{array}{l}\mathrm{TPC}=5 \mathrm{mg} \mathrm{GAE} / \mathrm{g} \\
\mathrm{GC}=4 \mu \mathrm{g} \mathrm{GAE} / \mathrm{g} \\
\mathrm{CT}=0.18 \% \mathrm{LCE} / \mathrm{g} \\
\mathrm{TFC}=0.1 \mathrm{mg} \mathrm{CTE} / \mathrm{g}\end{array}$ & Aremu et al., [71] \\
\hline Uapaca nitida & Leaves & Acetone & $\begin{array}{l}\mathrm{TPC}=26.08 \mathrm{mg} / \mathrm{g} \mathrm{GAE} \\
\mathrm{TFC}=20.31 \mathrm{mg} / \mathrm{g} \mathrm{QE}\end{array}$ & Dzoyem and Eloff [85] \\
\hline $\begin{array}{l}\text { Virgilia divaricata } \\
\text { Adamson }\end{array}$ & Leaves & Acetone & $\begin{array}{l}\mathrm{TPC}=137.3 \mathrm{mg} / \mathrm{g} \mathrm{GAE} \\
\mathrm{TFC}=15.3 \mathrm{mg} \mathrm{QE} / \mathrm{g}\end{array}$ & Dzoyem et al., [67] \\
\hline Ziziphus rivularis Codd & Leaves & Acetone & $\begin{array}{l}\mathrm{TPC}=182.79 \mathrm{mg} / \mathrm{g} \text { GAE } \\
\mathrm{TFC}=46.88 \mathrm{mg} \mathrm{QE} / \mathrm{g}\end{array}$ & Dzoyem and Eloff [85] \\
\hline
\end{tabular}


In recent times, increasing evidence from several studies on polyphenolic compounds from medicinal plants support their biological and pharmaceutical importance in maintaining animal health and overall productivity [91]. For example, betulinic acid and lupeol were successfully isolated from Curtisia dentata [81], which is one of the woody plants recorded in our inventory (Table 2). Subsequently, both compounds demonstrated a moderate degree of an anthelmintic effect $(200$ and $1000 \mu \mathrm{g} / \mathrm{mL})$ against parasitic nematodes. However, the relatively higher concentration required for the compounds to be effective limits their clinical relevance as an anthelmintic for livestock.

\section{Conclusions}

The current review entailed an overview of the role and contributions of woody plants in ethnoveterinary medicine in South Africa. We highlighted the richness of South Africa's flora as a medicinal resource and the effectiveness of woody plants used in ethnoveterinary medicine. Terminalia sericea and Ziziphus mucronata were the most commonly utilised woody plants based on existing indigenous knowledge. The extensive utilisation of some plant parts (e.g., bark and roots) remain a major concern due to the potential detrimental effects of the indiscriminate harvesting of such parts may have on the survival and sustainability of the woody plants. The majority $(80 \%)$ of woody plants with indigenous knowledge related to their applications in the management of animal health remain poorly evaluated in terms of their biological efficacy and phytochemical composition. Nevertheless, some of the woody plants (e.g., Alsophila dregei, Cussonia spicata, Indigofera frutescens, Leucosidea sericea, and Maesa lanceolata) have demonstrated promising biological activities, mainly in antibacterial and anthelminthic assays. Given the pre-dominantly in vitro based assays currently being utilised, there is an urgent need to evaluate woody plants with promising biological effect in appropriate in vivo models. The test organisms need to have direct relevance to prevailing health challenges facing livestock in rural areas where the use of woody plants have been widely documented. In terms of the phytochemical profiles, South African woody plants have a rich pool of chemicals with potential therapeutic effects.

Author Contributions: Conceptualization, K.M.S. and A.O.A.; formal analysis, K.M.S., J.A.A. and A.O.A.; investigation, K.M.S., J.A.A. and A.O.A.; writing—original draft preparation K.M.S., J.A.A. and A.O.A.; writing-review and editing, J.A.A., M.S., R.V.N. and A.O.A.; supervision, M.S., R.V.N., and A.O.A.; project administration, A.O.A.; funding acquisition, A.O.A. All authors have read and agreed to the published version of the manuscript.

Funding: This research was wholly funded by the National Research Foundation (NRF, Indigenous Knowledge Systems Research Grant, UID: 118585) Pretoria, South Africa. We thank North-West University for additional financial support for the project. AOA appreciates the financial support from North-West University UCDG: Staff Development-Advancement of Research Profiles: Mobility Grant (NW 1EU0130) for outgoing academic visits. The Article Processing Charge (APC) was paid by the Faculty of Natural and Agricultural Sciences, North-West University, South Africa. We appreciate the institutional support from North-West University, South Africa.

Institutional Review Board Statement: Not applicable.

Informed Consent Statement: Not applicable.

Data Availability Statement: All data are included as part of the manuscript.

Acknowledgments: We appreciate institutional support from North-West University.

Conflicts of Interest: The authors declare no conflict of interest. The National Research Foundation had no role in the design of the study; in the collection, analyses, or interpretation of data; in the writing of the manuscript; or in the decision to publish the results. 


\section{References}

1. Comaroff, J.L.; Comaroff, J. Goodly beasts, beastly goods: Cattle and commodities in a South African context. Am. Ethnol. 1990, 17, 195-216. [CrossRef]

2. Mapiye, O.; Chikwanha, O.C.; Makombe, G.; Dzama, K.; Mapiye, C. Livelihood, food and nutrition security in Southern Africa: What role do indigenous cattle genetic resources play? Diversity 2020, 12, 74. [CrossRef]

3. Suroowan, S.; Javeed, F.; Ahmad, M.; Zafar, M.; Noor, M.J.; Kayani, S.; Javed, A.; Mahomoodally, M.F. Ethnoveterinary health management practices using medicinal plants in South Asia-A review. Vet. Res. Commun. 2017, 41, 147-168. [CrossRef]

4. Lans, C.; Sant, C.; Georges, K. Ethnoremedies used for horses in British Columbia and Trinidad and Tobago. In Ethnoveterinary Medicine: Present and Future Concepts; McGaw, L.J., Abdalla, M.A., Eds.; Springer International Publishing: Cham, Switzerland, 2020; pp. 57-71. [CrossRef]

5. $\quad$ Borges, A.K.M.; Barboza, R.R.D.; Souto, W.M.S.; Alves, R.R.N. Natural remedies for animal health in Latin America. In Ethnoveterinary Medicine: Present and Future Concepts; McGaw, L.J., Abdalla, M.A., Eds.; Springer International Publishing: Cham, Switzerland, 2020; pp. 311-344. [CrossRef]

6. Mayer, M.; Zbinden, M.; Vogl, C.R.; Ivemeyer, S.; Meier, B.; Amorena, M.; Maeschli, A.; Hamburger, M.; Walkenhorst, M. Swiss ethnoveterinary knowledge on medicinal plants-A within-country comparison of Italian speaking regions with north-western German speaking regions. J. Ethnobiol. Ethnomed. 2017, 13, 1. [CrossRef]

7. Galaty, J.G. Being "Maasai"; being "People-of-cattle": Ethnic shifters in East Africa. Am. Ethnol. 1982, 9, 1-20. [CrossRef]

8. Kazanc1, C.; Oruç, S.; Mosulishvili, M. Ethnoveterinary and fodder plants used among transhumant communities around Georgia-Turkey border, in the Western Lesser Caucasus. Ethnobot. Res. Appl. 2021, 21, 28. [CrossRef]

9. McCorkle, C.M. Back to the future: Lessons from ethnoveterinary RD\&E for studying and applying local knowledge. Agric. Hum. Values 1995, 12, 52-80. [CrossRef]

10. Khan, K.; Rahman, I.U.; Calixto, E.S.; Ali, N.; Ijaz, F. Ethnoveterinary therapeutic practices and conservation status of the medicinal flora of Chamla valley, Khyber Pakhtunkhwa, Pakistan. Front. Vet. Sci. 2019, 6, 122. [CrossRef] [PubMed]

11. Shrubok, A. Belarusian ethnoveterinary medicine: Ritual practices and traditional remedies. In Ethnoveterinary Medicine: Present and Future Concepts; McGaw, L.J., Abdalla, M.A., Eds.; Springer International Publishing: Cham, Switzerland, 2020; pp. 375-390. [CrossRef]

12. Zorloni, A. Toward a better understanding of African ethnoveterinary medicine and husbandry. In Ethnoveterinary Medicine: Present and Future Concepts; McGaw, L.J., Abdalla, M.A., Eds.; Springer International Publishing: Cham, Switzerland, 2020; pp. 151-172. [CrossRef]

13. McCorkle, C.M. An introduction to ethnoveterinary research and development. J. Ethnobiol. 1986, 6, 129-149.

14. Aziz, M.A.; Khan, A.H.; Pieroni, A. Ethnoveterinary plants of Pakistan: A review. J. Ethnobiol. Ethnomed. 2020, 16, 25. [CrossRef] [PubMed]

15. McGaw, L.J.; Famuyide, I.M.; Khunoana, E.T.; Aremu, A.O. Ethnoveterinary botanical medicine in South Africa: A review of research from the last decade (2009 to 2019). J. Ethnopharmacol. 2020, 257, 112864. [CrossRef] [PubMed]

16. Hoveka, L.N.; van der Bank, M.; Davies, T.J. Evaluating the performance of a protected area network in South Africa and its implications for megadiverse countries. Biol. Conserv. 2020, 248, 108577. [CrossRef]

17. Germishuizen, G.; Meyer, N. Plants of Southern Africa: An Annotated Checklist; National Botanical Institute Pretoria: Pretoria, South Africa, 2003.

18. Van Staden, J. Ethnobotany in South Africa. J. Ethnopharmacol. 2008, 119, 329-330. [CrossRef]

19. Da Silva, T.C.; da Silva, J.M.; Ramos, M.A. What factors guide the selection of medicinal plants in a local pharmacopoeia? A case study in a rural community from a historically transformed atlantic forest landscape. Evid.-Based Complement. Altern. Med. 2018, 2018, 2519212. [CrossRef]

20. Muleba, I.; Yessoufou, K.; Rampedi, I.T. Testing the non-random hypothesis of medicinal plant selection using the woody flora of the Mpumalanga Province, South Africa. Environ. Dev. Sustain. 2021, 23, 4162-4173. [CrossRef]

21. De Albuquerque, U.P.; Farias Paiva de Lucena, R. Can apparency affect the use of plants by local people in tropical forests? Interciencia 2005, 30, 506-510.

22. Douwes, E.; Crouch, N.R.; Edwards, T.J.; Mulholland, D.A. Regression analyses of southern African ethnomedicinal plants: Informing the targeted selection of bioprospecting and pharmacological screening subjects. J. Ethnopharmacol. 2008, 119, 356-364. [CrossRef]

23. Daru, B.H.; Berger, D.K.; Wyk, A.E. Opportunities for unlocking the potential of genomics for African trees. New Phytol. 2016, 210, 772-778. [CrossRef]

24. Venter, F.; Venter, J.-A. Making the Most of Indigenous Trees; Briza Publications: Pretoria, South Africa, 2002.

25. Van Wyk, A.S.; Prinsloo, G. A review of the ethnobotanical uses, pharmacology, toxicology, management and cultivation of selected South African protected multi-purpose tree species. S. Afr. J. Bot. 2019, 124, 258-269. [CrossRef]

26. Moyo, M.; Aremu, A.O.; Van Staden, J. Medicinal plants: An invaluable, dwindling resource in sub-Saharan Africa. J. Ethnopharmacol. 2015, 174, 595-606. [CrossRef] [PubMed]

27. Yaoitcha, A.S.; Houehanou, T.D.; Fandohan, A.B.; Houinato, M.R.B. Prioritization of useful medicinal tree species for conservation in Wari-Maro Forest Reserve in Benin: A multivariate analysis approach. For. Policy Econ. 2015, 61, 135-146. [CrossRef] 
28. Yirgu, A.; Mohammed, K.; Geldenhuys, C.J. Useful medicinal tree species of Ethiopia: Comprehensive review. S. Afr. J. Bot. 2019, 122, 291-300. [CrossRef]

29. Ahoyo, C.C.; Houéhanou, T.D.; Yaoïtcha, A.S.; Prinz, K.; Glèlè Kakaï, R.; Sinsin, B.A.; Houinato, M.R.B. Traditional medicinal knowledge of woody species across climatic zones in Benin (West Africa). J. Ethnopharmacol. 2021, 265, 113417. [CrossRef] [PubMed]

30. Van Andel, T.; Myren, B.; van Onselen, S. Ghana's herbal market. J. Ethnopharmacol. 2012, 140, 368-378. [CrossRef]

31. Rivera, D.; Allkin, R.; Obón, C.; Alcaraz, F.; Verpoorte, R.; Heinrich, M. What is in a name? The need for accurate scientific nomenclature for plants. J. Ethnopharmacol. 2014, 152, 393-402. [CrossRef]

32. Weckerle, C.S.; de Boer, H.J.; Puri, R.K.; van Andel, T.; Bussmann, R.W.; Leonti, M. Recommended standards for conducting and reporting ethnopharmacological field studies. J. Ethnopharmacol. 2018, 210, 125-132. [CrossRef]

33. Chitura, T.; Muvhali, P.; Shai, K.; Mushonga, B.; Kandiwa, E. Use of medicinal plants by livestock farmers in a local municipality in Vhembe district, South Africa. Appl. Ecol. Environ. Res. 2018, 16, 6589-6605. [CrossRef]

34. Dold, A.P.; Cocks, M.L. Traditional veterinary medicine in the Alice district of the Eastern Cape Province, South Africa. S. Afr. J. Sci. 2001, 97, 375-379.

35. Kambizi, L. Indigenous plants for ethnoveterinary uses in the Pondoland, South Africa. In Proceedings of the XXIX International Horticultural Congress on Horticulture: Sustaining Lives, Livelihoods and Landscapes: V World Congress on Medicinal and Aromatic Plants and International Symposium on Plants, as Factories of Natural Substances, Edible and Essential Oils, Brisbane, QLD, Australia, 17 August 2014; pp. 309-314.

36. Khunoana, E.T.; Madikizela, B.; Erhabor, J.O.; Nkadimeng, S.M.; Arnot, L.F.; Van Wyk, I.; McGaw, L.J. A survey of plants used to treat livestock diseases in the Mnisi community, Mpumalanga, South Africa, and investigation of their antimicrobial activity. $S$. Afr. J. Bot. 2019, 126, 21-29. [CrossRef]

37. Luseba, D.; Tshisikhawe, M. Medicinal plants used in the treatment of livestock diseases in Vhembe region, Limpopo province, South Africa. J. Med. Plants Res. 2013, 7, 593-601.

38. Luseba, D.; Van der Merwe, D. Ethnoveterinary medicine practices among Tsonga speaking people of South Africa. Onderstepoort J. Vet. Res. 2006, 73, 115-122. [CrossRef]

39. Magwede, K.; Tshisikhawe, M.P.; Luseba, D.; Bhat, R.B. Ethnobotanical survey of medicinal plants used in treatment of ticks. Int. J. Exp. Bot. 2014, 83, 155-165.

40. Mahlo, S.M. Antibacterial Activity of Selected Plants Used in Ethnoveterinary Medicine. Master's Thesis, University of Limpopo (Turfloop Campus), Turfloop, South Africa, 2006.

41. Maphosa, V.; Masika, P.J. Ethnoveterinary uses of medicinal plants: A survey of plants used in the ethnoveterinary control of gastro-intestinal parasites of goats in the Eastern Cape Province, South Africa. Pharm. Biol. 2010, 48, 697-702. [CrossRef] [PubMed]

42. Mkwanazi, M.V.; Ndlela, S.Z.; Chimonyo, M. Utilisation of indigenous knowledge to control ticks in goats: A case of KwaZuluNatal Province, South Africa. Trop. Anim. Health Prod. 2020, 52, 1375-1383. [CrossRef] [PubMed]

43. Moichwanetse, B.I.; Ndhlovu, P.T.; Sedupane, G.; Aremu, A.O. Ethno-veterinary plants used for the treatment of retained placenta and associated diseases in cattle among Dinokana communities, North West Province, South Africa. S. Afr. J. Bot. 2020, 132, 108-116. [CrossRef]

44. Moyo, B.; Masika, P.J. Tick control methods used by resource-limited farmers and the effect of ticks on cattle in rural areas of the Eastern Cape Province, South Africa. Trop. Anim. Health Prod. 2009, 41, 517-523. [CrossRef] [PubMed]

45. Mthi, S.; Rust, J.; Morgenthal, T.; Moyo, B. An ethno-veterinary survey of medicinal plants used to treat bacterial diseases of livestock in three geographical areas of the Eastern Cape Province, South Africa. J. Med. Plants Res. 2018, 12, $240-247$.

46. Mwale, M.; Masika, P.J. Ethno-veterinary control of parasites, management and role of village chickens in rural households of Centane district in the Eastern Cape, South Africa. Trop. Anim. Health Prod. 2009, 41, 1685-1693. [CrossRef] [PubMed]

47. Ndou, R.V. A Study of Ethnoveterinary medicIne in the North West Province, South Africa. Master's Thesis, North-West University, Mmabatho, South Africa, 2018.

48. Ramovha, L.I.; Van Wyk, A.E. Ethnoveterinary practices of the Vhavenda, South Africa, in the treatment of redwater (mali) in cattle. Indilinga Afr. J. Indig. Knowl. Syst. 2016, 15, 314-327.

49. Rwodzi, M. Alternative Remedies Used by Resource-Limited Farmers in the Treatment and Manipulation of the Reproductive System of Non-Descript Goats in the Eastern Cape Province, South Africa. Master's Thesis, University of Fort Hare, Alice, South Africa, 2014.

50. Sanhokwe, M.; Mupangwa, J.; Masika, P.J.; Maphosa, V.; Muchenje, V.; Masika, P.J. Medicinal plants used to control internal and external parasites in goats. Onderstepoort J. Vet. Res. 2016, 83, a1016. [CrossRef]

51. Soyelu, O.T.; Masika, P.J. Traditional remedies used for the treatment of cattle wounds and myiasis in Amatola Basin, Eastern Cape Province, South Africa. Onderstepoort J. Vet. Res. 2009, 76, 393-397. [CrossRef] [PubMed]

52. Van der Merwe, D.; Swan, G.E.; Botha, C.J. Use of ethnoveterinary medicinal plants in cattle by Setswana-speaking people in the Madikwe area of the North West Province of South Africa. J. S. Afr. Vet. Assoc. 2001, 72, 189-196. [CrossRef] [PubMed]

53. Gaoue, O.G.; Coe, M.A.; Bond, M.; Hart, G.; Seyler, B.C.; McMillen, H. Theories and major hypotheses in ethnobotany. Econ. Bot. 2017, 71, 269-287. [CrossRef] 
54. Hyvärinen, O.; Timm Hoffman, M.; Reynolds, C. Vegetation dynamics in the face of a major land-use change: A 30-year case study from semi-arid South Africa. Afr. J. Range Forage Sci. 2019, 36, 141-150. [CrossRef]

55. Yirga, G.; Teferi, M.; Gidey, G.; Zerabruk, S. An ethnoveterinary survey of medicinal plants used to treat livestock diseases in Seharti-Samre district, Northern Ethiopia. Afr. J. Plant Sci. 2012, 6, 113-119.

56. McCorkle, C.M.; Mathias-Mundy, E. Ethnoveterinary Medicine in Africa. Afr. J. Int. Afr. Inst. 1992, 62, 59-93. [CrossRef]

57. Nchu, F.; Nana, P.; Msalya, G.; Magano, S.R. Ethnoveterinary practices for control of ticks in Africa. In Ethnoveterinary Medicine: Present and Future Concepts; McGaw, L.J., Abdalla, M.A., Eds.; Springer International Publishing: Cham, Switzerland, 2020; pp. 99-122. [CrossRef]

58. Van Wyk, B.E. A family-level floristic inventory and analysis of medicinal plants used in Traditional African Medicine. J. Ethnopharmacol. 2020, 249, 112351. [CrossRef]

59. Chakale, M.V.; Mwanza, M.; Aremu, A.O. Ethnoveterinary knowledge and biological evaluation of plants used for mitigating cattle diseases: A critical insight into the trends and patterns in South Africa. Front. Vet. Sci. 2021, 8, 891. [CrossRef] [PubMed]

60. Eloff, J.N.; McGaw, L.J. Application of plant extracts and products in veterinary infections. In New Strategies Combating Bacterial Infection; Ahmad, I., Aqil, F., Eds.; Wiley-VCH Verlag GmbH \& Co. KGaA: Weinheim, Germany, 2009; pp. 205-228. [CrossRef]

61. Abdalla, M.A.; McGaw, L.J. Introduction. In Ethnoveterinary Medicine: Present and Future Concepts; McGaw, L.J., Abdalla, M.A., Eds.; Springer International Publishing: Cham, Switzerland, 2020; pp. 1-3. [CrossRef]

62. Eloff, J.N.; McGaw, L.J. Plant extracts used to manage bacterial, fungal, and parasitic infections in Southern Africa. In Modern Phytomedicine: Turning Medicinal Plants into Drugs; Ahmad, I., Aqil, F., Owais, M., Eds.; Wiley-VCH Verlag GmbH \& Co. KGaA: Weinheim, Germany, 2006; pp. 97-121. [CrossRef]

63. Eloff, J.N. Avoiding pitfalls in determining antimicrobial activity of plant extracts and publishing the results. BMC Complementary Altern. Med. 2019, 19, 106. [CrossRef] [PubMed]

64. Van Vuuren, S.; Holl, D. Antimicrobial natural product research: A review from a South African perspective for the years 2009-2016. J. Ethnopharmacol. 2017, 208, 236-252. [CrossRef]

65. Heinrich, M.; Appendino, G.; Efferth, T.; Fürst, R.; Izzo, A.A.; Kayser, O.; Pezzuto, J.M.; Viljoen, A. Best practice in researchOvercoming common challenges in phytopharmacological research. J. Ethnopharmacol. 2020, 246, 112230. [CrossRef] [PubMed]

66. Elisha, I.L.; Dzoyem, J.-P.; Botha, F.S.; Eloff, J.N. The efficacy and safety of nine South African medicinal plants in controlling Bacillus anthracis Sterne vaccine strain. BMC Complementary Altern. Med. 2016, 16, 5. [CrossRef] [PubMed]

67. Dzoyem, J.P.; McGaw, L.J.; Eloff, J.N. In vitro antibacterial, antioxidant and cytotoxic activity of acetone leaf extracts of nine underinvestigated Fabaceae tree species leads to potentially useful extracts in animal health and productivity. BMC Complementary Altern. Med. 2014, 14, 147. [CrossRef] [PubMed]

68. Adamu, M.; Naidoo, V.; Eloff, J.N. The antibacterial activity, antioxidant activity and selectivity index of leaf extracts of thirteen South African tree species used in ethnoveterinary medicine to treat helminth infections. BMC Vet. Res. 2014, 10, 52. [CrossRef] [PubMed]

69. Aremu, A.O.; Fawole, O.A.; Chukwujekwu, J.C.; Light, M.E.; Finnie, J.F.; Van Staden, J. In vitro antimicrobial, anthelmintic and cyclooxygenase-inhibitory activities and phytochemical analysis of Leucosidea sericea. J. Ethnopharmacol. 2010, 131, 22-27. [CrossRef] [PubMed]

70. McGaw, L.J.; Van der Merwe, D.; Eloff, J.N. In vitro anthelmintic, antibacterial and cytotoxic effects of extracts from plants used in South African ethnoveterinary medicine. Vet. J. 2007, 173, 366-372. [CrossRef]

71. Aremu, A.O.; Ndhlala, A.R.; Fawole, O.A.; Light, M.E.; Finnie, J.F.; Van Staden, J. In vitro pharmacological evaluation and phenolic content of ten South African medicinal plants used as anthelmintics. S. Afr. J. Bot. 2010, 76, 558-566. [CrossRef]

72. Masika, P.J.; Afolayan, A.J. Antimicrobial activity of some plants used for the treatment of livestock disease in the Eastern Cape, South Africa. J. Ethnopharmacol. 2002, 83, 129-134. [CrossRef]

73. Luseba, D.; Elgorashi, E.; Ntloedibe, D.; Van Staden, J. Antibacterial, anti-inflammatory and mutagenic effects of some medicinal plants used in South Africa for the treatment of wounds and retained placenta in livestock. S. Afr. J. Bot. 2007, 73, 378-383. [CrossRef]

74. Aremu, A.O.; Finnie, J.F.; Van Staden, J. Potential of South African medicinal plants used as anthelmintics-Their efficacy, safety concerns and reappraisal of current screening methods. S. Afr. J. Bot. 2012, 82, 134-150. [CrossRef]

75. Fouche, G.; Sakong, B.M.; Adenubi, O.T.; Pauw, E.; Leboho, T.; Wellington, K.W.; Eloff, J.N. Anthelmintic activity of acetone extracts from South African plants used on egg hatching of Haemonchus contortus. Onderstepoort J. Vet. Res. 2016, 83, a1164. [CrossRef]

76. Adamu, M.; Naidoo, V.; Eloff, J.N. Efficacy and toxicity of thirteen plant leaf acetone extracts used in ethnoveterinary medicine in South Africa on egg hatching and larval development of Haemonchus contortus. BMC Vet. Res. 2013, 9, 38. [CrossRef]

77. Githiori, J.B.; Athanasiadou, S.; Thamsborg, S.M. Use of plants in novel approaches for control of gastrointestinal helminths in livestock with emphasis on small ruminants. Vet. Parasitol. 2006, 139, 308-320. [CrossRef]

78. Bürglin, T.R.; Lobos, E.; Blaxter, M.L. Caenorhabditis elegans as a model for parasitic nematodes. Int. J. Parasitol. 1998, $28,395-411$. [CrossRef]

79. Geary, T.G.; Thompson, D.P.; Klein, R.D. Mechanism-based screening: Discovery of the next generation of anthelmintics depends upon more basic research. Int. J. Parasitol. 1999, 29, 105-112. [CrossRef] 
80. McGaw, L.J.; Rabe, T.; Sparg, S.G.; Jäger, A.K.; Eloff, J.N.; Van Staden, J. An investigation on the biological activity of Combretum species. J. Ethnopharmacol. 2001, 75, 45-50. [CrossRef]

81. Shai, L.J.; Bizimenyera, E.S.; Bagla, V.; McGaw, L.J.; Eloff, J.N. Curtisia dentata (Cornaceae) leaf extracts and isolated compounds inhibit motility of parasitic and free-living nematodes. Onderstepoort J. Vet. Res. 2009, 76, 249-256. [CrossRef]

82. Gülçin, İ. Antioxidant activity of food constituents: An overview. Arch. Toxicol. 2012, 86, 345-391. [CrossRef]

83. Granato, D.; Shahidi, F.; Wrolstad, R.; Kilmartin, P.; Melton, L.D.; Hidalgo, F.J.; Miyashita, K.; Camp, J.v.; Alasalvar, C.; Ismail, A.B.; et al. Antioxidant activity, total phenolics and flavonoids contents: Should we ban in vitro screening methods? Food Chem. 2018, 264, 471-475. [CrossRef]

84. Houghton, P.J.; Howes, M.J.; Lee, C.C.; Steventon, G. Uses and abuses of in vitro tests in ethnopharmacology: Visualizing an elephant. J. Ethnopharmacol. 2007, 110, 391-400. [CrossRef]

85. Dzoyem, J.P.; Eloff, J.N. Anti-inflammatory, anticholinesterase and antioxidant activity of leaf extracts of twelve plants used traditionally to alleviate pain and inflammation in South Africa. J. Ethnopharmacol. 2015, 160, 194-201. [CrossRef] [PubMed]

86. Sserunkuma, P.; McGaw, L.J.; Nsahlai, I.V.; Van Staden, J. Selected southern African medicinal plants with low cytotoxicity and good activity against bovine mastitis pathogens. S. Afr. J. Bot. 2017, 111, 242-247. [CrossRef]

87. Altemimi, A.; Lakhssassi, N.; Baharlouei, A.; Watson, D.G.; Lightfoot, D.A. Phytochemicals: Extraction, isolation, and identification of bioactive compounds from plant extracts. Plants 2017, 6, 42. [CrossRef] [PubMed]

88. Gálvez, M.; Martín-Cordero, C.; Ayuso, M.J. Pharmacological activities of iridoids biosynthesized by route II. In Studies in Natural Products Chemistry; Attaur, R., Ed.; Elsevier: Amsterdam, The Netherlands, 2005; Volume 32.

89. Brielmann, H.L.; Setzer, W.N.; Kaufman, P.B.; Kirakosyan, A.; Cseke, L.J. Phytochemicals: The chemical components of plants. In Natural Products from Plants, 2nd ed.; Cseke, L.J., Kirakosyan, A., Kaufman, P.B., Warber, S.L., Duke, J.A., Brielmann, H.L., Eds.; Taylor and Francis Group: Boca Raton, FL, USA, 2006; pp. 1-49.

90. Olaokun, O.O.; Mkolo, N.M.; Mogale, M.A.; King, P.H. Phytochemical screening, antioxidant, anti-inflammatory and glucose utilization activities of three South African plants used traditionally to treat diseases. Biol. Med. 2017, 9, 1000412. [CrossRef]

91. Hajam, Y.A.; Rai, S.; Kumar, R.; Bashir, M.; Malik, J.A. Phenolic compounds from medicinal herbs: Their role in animal health and diseases-A new approach for sustainable welfare and development. In Plant Phenolics in Sustainable Agriculture; Lone, R., Shuab, R., Kamili, A.N., Eds.; Springer: Singapore, 2020; Volume 1, pp. 221-239. [CrossRef] 